\title{
Oceanographic characteristics of the Adriatic Sea - Support to secondary HAOP spread through natural dispersal
}

\author{
Romina Kraus $^{\mathrm{a}, *, 1}$, Federica Grilli ${ }^{\mathrm{b}, 1}$, Nastjenjka Supića ${ }^{\mathrm{a}}$, Ivica Janekovićc,d, Marina Brailo ${ }^{\mathrm{e}}$, \\ Magdalena Cara ${ }^{\mathrm{f}}$, Ana Bratoš Cetinić ${ }^{\mathrm{e}}$, Alessandra Campanelli ${ }^{\mathrm{b}}$, Stefano Cozzi ${ }^{\mathrm{g}}$, \\ Raffaele D'Adamo $^{\mathrm{h}}$, Tamara Djakovac ${ }^{\mathrm{a}}$, Mathieu Dutour-Sikirićc ${ }^{\mathrm{c}}$, Vesna Flander-Putrle ${ }^{\mathrm{i}}$, \\ Janja Francé ${ }^{i}$, Danijela Joksimović ${ }^{j}$, Katja Klun ${ }^{\mathrm{i}}$, Jerina Kolitari ${ }^{\mathrm{f}}$, Martina Kralj ${ }^{\mathrm{k}}$, \\ Grozdan Kušpilić ${ }^{1}$, Mauro Marini ${ }^{\mathrm{b}}$, Frano Matićl ${ }^{\text {, Josip Mikuše }}$, Živana Ninčević-Gladan ${ }^{1}$, \\ Marco Pansera $^{\mathrm{m}}$, Marijana Pećarević ${ }^{\mathrm{e}}$, Robert Precali ${ }^{\mathrm{a}}$, Ivana Prusina ${ }^{\mathrm{e}}$, Federica Relitti ${ }^{\mathrm{k}}$, \\ Angela Santucci $^{\mathrm{h}, \mathrm{n}}$, Antonietta Specchiulli ${ }^{\mathrm{h}}$, Denis Škalic ${ }^{\mathrm{a}}$
}

${ }^{a}$ Ruđer Bošković Institute, Center for Marine Research, G. Paliage 5, 52210 Rovinj, Croatia

${ }^{\mathrm{b}}$ National Research Council, IRBIM, Largo Fiera della Pesca 2, 60125 Ancona, Italy

${ }^{\mathrm{c}}$ Ruđer Bošković Institute, Division for Marine and Environmental Research, Bijenička 54, 10000 Zagreb, Croatia

${ }^{\mathrm{d}}$ The University of Western Australia, Australia

${ }^{\mathrm{e}}$ University of Dubrovnik, Department of Aquaculture, Ćira Carića 4, 20000 Dubrovnik, Croatia

${ }^{\mathrm{f}}$ Agricultural University of Tirana, Kodër Kamëz, SH1, 1000 Tirana, Albania

${ }^{g}$ National Research Council, Institute of Marine Sciences, Strada Statale 14, 34149 Trieste, Italy

${ }^{\mathrm{h}}$ National Research Council, CNR-IRBIM, via Pola 4, 71010 Lesina (FG), Italy

${ }^{\mathrm{i}}$ National Institute of Biology, Marine Biology Station, Fornače 41, 6330 Piran, Slovenia

${ }^{\mathrm{j}}$ University of Montenegro, Institute of Marine Biology, Dobrota bb, 85330 Kotor, Montenegro

${ }^{\mathrm{k}}$ Sezione di Oceanografia, Istituto Nazionale di Oceanografia e di Geofisica Sperimentale - OGS, via Auguste Piccard 54, 34151 Trieste, Italy

${ }^{1}$ Institute of Oceanography and Fisheries, Šetalište I. Meštrovića 63, 21000 Split, Croatia

${ }^{\mathrm{m}}$ National Research Council, Institute of Marine Sciences, Arsenale Tesa 104 Castello 2737/f, 30122 Venice, Italy

${ }^{\mathrm{n}}$ Hydrographic Institute of the Italian Navy, Passo dell'Osservatorio 4, 16134 Genova, Italy

\section{A R T I C L E I N F O}

\section{Keywords:}

Adriatic Sea

Ballast water

Port

Non-indigenous species

Harmful aquatic organisms and pathogens BALMAS

\begin{abstract}
A B S T R A C T
Vessels, specifically ballast water and hull fouling, are a major vector for the introduction of non-indigenous species (NIS) in European seas. The Mediterranean is one of the world's marine regions where their invasion is heaviest. The shallow Adriatic basin is a highly sensitive area that is already experiencing its consequences. The secondary spread of NIS over a wider area through natural dispersion is a complex process that depends on a wide range of oceanographic factors. This work analysed the dataset of the BALMAS project, in whose framework twelve ports in the Adriatic Sea were subjected to a Port Baseline Survey (PBS), to estimate the natural spread of NIS organisms from their port of arrival to the wider Adriatic basin. Its findings indicate that the prevailing water circulation patterns facilitate the natural dispersal of harmful aquatic organisms and pathogens (HAOP).
\end{abstract}

\footnotetext{
* Corresponding author.

E-mail addresses: kraus@cim.irb.hr (R. Kraus), federica.grilli@cnr.it (F. Grilli), supic@cim.irb.hr (N. Supić), ivica@irb.hr, ivica.janekovic@uwa.edu (I. Janeković), marina.brailo@unidu.hr (M. Brailo), magdacara@ubt.edu.al (M. Cara), abratos@unidu.hr (A.B. Cetinić), alessandra.campanelli@cnr.it (A. Campanelli), stefano.cozzi@ts.ismar.cnr.it (S. Cozzi), raffaele.dadamo@fg.ismar.cnr.it (R. D'Adamo), djakovac@cim.irb.hr (T. Djakovac), Mathieu.Andre.Dutour-Sikiric@irb.hr (M. Dutour-Sikirić), Vesna.FlanderPutrle@nib.si (V. Flander-Putrle), Janja.France@nib.si (J. Francé), danijela.j@ac.me (D. Joksimović), Katja.Klun@nib.si (K. Klun), j.kolitari@gmail.com (J. Kolitari), mkralj@inogs.it (M. Kralj),

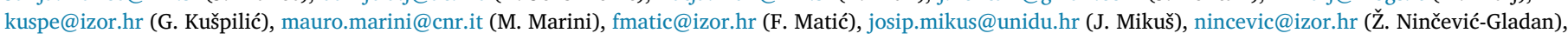
marco.pansera@ve.ismar.cnr.it (M. Pansera), marijana.pecarevic@unidu.hr (M. Pećarević), precali@cim.irb.hr (R. Precali), ivana.prusina@unidu.hr (I. Prusina), frelitti@inogs.it (F. Relitti), angela.santucci@fg.ismar.cnr.it (A. Santucci), antonietta.specchiulli@fg.ismar.cnr.it (A. Specchiulli), Denis.Skalic@irb.hr (D. Škalic).

${ }^{1}$ These authors contributed equally to the work.
} 


\section{Introduction}

The primary pathway for the introduction of non-indigenous species (NIS) in Europe's and in most other seas is shipping; ballast water and hull fouling are the most important vectors (Katsanevakis et al., 2013; GISP, 2008 and references therein; Minton et al., 2005; Molnar et al., 2008; Ruiz et al., 2000). Studies of NIS recorded in the Mediterranean have indicated that the primary pathways may include the Suez Canal, vessels and aquaculture (e.g. Galil, 2009; Tsiamis et al., 2018). However, a contribution also seems to be provided by secondary NIS spread via vessels after their original introduction (Galil, 2009). Yet, no clear relationship has been found between the biological traits of NIS and such pathways, especially where carriage by vessels is concerned (e.g. Cardeccia et al., 2016). This suggests that secondary spread might follow closely upon the first introduction of organisms at an early life stage and that all vectors should be managed in a similar way to mitigate the introduction of new propagules and the secondary spread of invasive NIS (Cardeccia et al., 2016).

Attempts have been made to predict which species are more likely to be successfully introduced and should thus be under close surveillance (e.g. Catford et al., 2012). According to a recent extensive study of the biological traits of the 68 most widespread multicellular NIS in Europe's seas, the most relevant traits for successful colonization are a high dispersal ability, a high reproduction rate, and ecological generalization (Cardeccia et al., 2016). However, the profile of the perfect invader of marine and brackish environments is difficult to sketch, since even species introduced by a single pathway, e.g. vessels, show heterogeneous biological traits. The most reliable indicator to date is past performance: widespread NIS are likely to disperse further (Galil et al., 2014).

Fortunately, successful invasions of introductions are relatively rare (Williamson and Fitter, 1996) and have been found to depend not only on the biological traits of NIS, but also on environmental features, i.e. the susceptibility of habitats to NIS establishment or proliferation, which has been defined as invasibility (Colautti et al., 2006).

Zaiko et al. (2007) performed a comprehensive study to identify the main factors driving the distribution of invasive aquatic species and the causes of habitat susceptibility to invasion and conducted an extensive analysis of the literature (Nilsson, 1984; Herbold and Moyle, 1986; Vitousek et al., 1997; Brooks, 1999; Simberloff and Von Holle, 1999; Davis et al., 2000; Ruiz et al., 1999; Nehring, 2002; Van der Velde et al., 2002; Ruiz and Hewitt, 2002). They conceived the model of an "invader-friendly habitat", which is characterized by the following features:

- favourable physical conditions to support diverse communities (a high richness in native species may be considered as an indicator of invasibility);

- the lack of certain species that are present in normal conditions ("vacant niches");

- disturbance due to natural or anthropogenic factors, e.g. a large storm and bottom dredging (each new disturbance event may promote a new surge of invasions);

- altered ecosystem properties due to earlier introductions, which create unstable conditions (successfully established habitat-engineering species should be considered as a powerful facilitative factor for further invasions);

- increased amounts of utilized resources, for instance due to eutrophication (a sudden increase in the nutrient load should be considered as a factor stimulating invisibility; e.g. Sara et al., 2018).

An important step towards NIS management was made in 2004, when the International Maritime Organisation (IMO) adopted the International Convention for the Control and Management of Ships' Ballast Water and Sediments (BWM Convention; IMO, 2004). The Convention, which entered into force 13 years later, on 8 September
2017, requires all ships to adopt a Ballast Water and Sediments Management Plan and to manage their ballast water (bw) according to specific procedures, calling on its Parties to monitor the effects of BWM in their waters individually or jointly (IMO, 2005). According to the BWM Convention, all aquatic organisms "which, if introduced into the sea including estuaries, or into fresh water courses, may create hazards to the environment, human health, property or resources, impair biological diversity or interfere with other legitimate uses of such areas" are harmful aquatic organisms and pathogens (HAOP). HAOP thus include all potentially harmful NIS and cryptogenic organisms impacting native aquatic species, including harmful algal bloom species and pathogens (David et al., 2013; Gollasch et al., 2015). Joint Port Baseline Surveys (PBS) in 12 Adriatic ports were one of the main goals of the BALMAS project (Ballast Water Management System for Adriatic Sea Protection).

The Adriatic Sea lies in the northernmost part of the Mediterranean Sea and can be approximated to a rectangular basin $800 \mathrm{~km}$ long and $200 \mathrm{~km}$ wide; its only connection with the Mediterranean Sea is through the $72 \mathrm{~km}$-wide Otranto Strait (Lipizer et al., 2014). The Adriatic can be divided into three areas: the northern Adriatic - the largest shelf area in the Mediterranean, bordered by $100 \mathrm{~m}$ isobaths and characterized by the largest riverine contributions in the basin (Cushman-Roisin et al., 2001); the central Adriatic - characterized by a mean depth of about $140 \mathrm{~m}$ and extending to the Palagruža Sill $(170 \mathrm{~m})$ and Jabuka Pit (JP) or Middle Adriatic Pit, whose mean depth is around $250 \mathrm{~m}$; and the southern Adriatic - which is connected to the Ionian Sea through the Otranto Sill (depth, $780 \mathrm{~m}$ ) and includes the South Adriatic Pit (SAP), the deepest area in the Adriatic (1200 m; Artegiani et al., 1997).

The main nutrient inputs to the Adriatic Sea come from surface runoff, underground water and urban discharges, and aeolian inputs (Marini et al., 2008). Temperature, salinity, nutrients, dissolved oxygen, and chlorophyll $a$ generally show a pronounced seasonal cycle and marked longitudinal gradients (Lipizer et al., 2014). From north to south, the Adriatic appears to be characterized by a progressive decline in nutrient concentrations in the surface layer and a decrease of seasonal cycle amplitude in middle and southern areas (Zavatarelli et al., 1998). In particular, the northern Adriatic is mostly influenced by coastal processes, which are characterized by higher mean nutrient values and a greater variability (Solidoro et al., 2009; Lipizer et al., 2014). This area is very sensitive to the prevailing wind regimes and to river forcing, which can induce the spread of the River Po plume as far as the eastern Adriatic coast (Jeffries and Lee, 2007). Nutrient levels in the northern Adriatic are determined by riverine inputs (e.g. Cozzi and Giani, 2011; Djakovac et al., 2015), which induce intense phytoplankton development in winter and autumn (e.g. Kraus and Supić, 2011). Nutrient distribution appears to be controlled both by water circulation patterns and by phytoplankton assimilation processes (Zavatarelli et al., 1998).

Analysis of the physical parameters collected in a 30-year dataset has demonstrated that the northern Adriatic has undergone an increment in salinity that may be a consequence of reduced riverine inputs (which involve higher salinity in coastal areas) combined with a greater seawater inflow along the eastern coast (Solidoro et al., 2009). Changes in salinity also depend on air-seawater fluxes, which are computed as the difference between precipitation and evaporation. Although evaporation in the northern Adriatic was on average higher in 2000-2009 than in 1972-1999 (Trieste; N. Supić, unpublished data), increased precipitation in 1972-1999 resulted in similar water fluxes in both periods. However, evaporation can exert a marked influence on geostrophic circulation patterns (see Lyons et al., 2007; Supić et al., 2012). In the Adriatic, it can induce more intense water mass movements, which are capable of carrying northwards warmer and highly saline water; the increase in surface density due to evaporation also affects water column stability. Furthermore, a clear reduction in orthophosphate and ammonia concentrations in coastal areas, probably due to new regulations on the control of nutrient loads, suggests a process of 
cultural oligotrophication (Mozetič et al., 2010; Marić et al., 2012; Djakovac et al., 2012). In contrast, nitrate concentrations have not decreased (Solidoro et al., 2009).

A basin-wide climatological analysis based on a recent dataset (Lipizer et al., 2014) has found a similar surface pattern in all seasons, which has been attributed to dilution of the Western Adriatic Current (WAC) by freshwater. The WAC is a water mass with reduced salinity, due to river inputs, which flows in southward direction from the northwestern Adriatic shelf, along the Italian coast, in the form of a narrow (10 to $50 \mathrm{~km}$-wide) surface current. In spring and summer, the WAC flows in north-eastern direction and nearly reaches the Croatian coast. The northern Italian rivers and atmospheric forcing play a key role in water circulation (Hopkins et al., 1999). Along the central and eastern Adriatic, a compensation inflow carries warmer and saltier water from the southern Adriatic and the Ionian Sea (Zore-Armanda, 1963; Artegiani et al., 1997; Cushman-Roisin et al., 2001). The bottom layer circulation seems to be especially pronounced in winter, when very dense water forms; notably, exceptionally dense water formed in winter 2012 (Janeković et al., 2014), firstly in the northernmost part of the basin and in Kvarner and Rijeka Bay (KRB). Dense water flows along the bottom, fills the deepest pits, and ultimately leaves the Adriatic (Vilibić and Supić, 2005).

\section{Aim}

This work investigates the feasibility of the secondary spread of harmful aquatic organisms and pathogens (HAOP) through natural dispersal after their primary introduction via ballast water in 12 Adriatic ports. The values of the abiotic parameters were obtained from the PBS dataset, whereas numerical modelling, measurements, and calculations were performed to gain a greater understanding of Adriatic water circulation patterns. The oceanographic characteristics of water in each port were compared to those found at stations established in adjacent open sea areas, to assess their ability to prevent or facilitate secondary HAOP spread. Modelling of water circulation patterns provided additional information, assuming that secondary HAOP spread is ultimately driven by the Adriatic circulation pattern.

\section{Methods}

The study methodology, including sampling strategy, field sampling and measurements, and sample processing and analysis, was based on the PBS Protocol (Ninčević Gladan et al., 2014), which was designed for the purposes of the BALMAS project.

\subsection{Sampling strategy}

The procedures applied to select the 12 ports (Durrës, Bar, Ploče, Split, Šibenik, Rijeka, Pula, Koper, Trieste, Venice, Ancona, and Bari; Fig. 1), the survey areas and the sampling sites are described in the PBS design plan reported in Kraus et al. (this issue). Temperature, salinity, and water transparency were measured at all sampling sites. To provide a more accurate characterization of port environmental conditions, nutrients, i.e. total inorganic nitrogen (TIN), orthophosphates, and orthosilicates, dissolved oxygen and chlorophyll (Chl) $a$ concentrations were also measured, when permitted by the resources of the partner responsible for the port. The methods and instruments used are listed in Tables 1a-1c. Samples were collected at least twice a year in spring and autumn, and where possible 3-4 times, in relation to the life cycle patterns and seasonal distribution of marine organisms. The decision was made to add the data collected in the previous three years to the PBS dataset if sampling had been consistent with the PBS protocol. Additional information on physical parameters was collected by measuring currents over a 12-month period in the north-eastern Adriatic. Numerical modelling of the Adriatic circulation was performed using tracers released at each of the 12 ports.

\subsection{Sampling stations}

The sampling stations selected in the 12 ports are listed in Table 2 . The abiotic parameters were recorded at 56 sampling stations (Table 3 in Kraus et al., this issue).

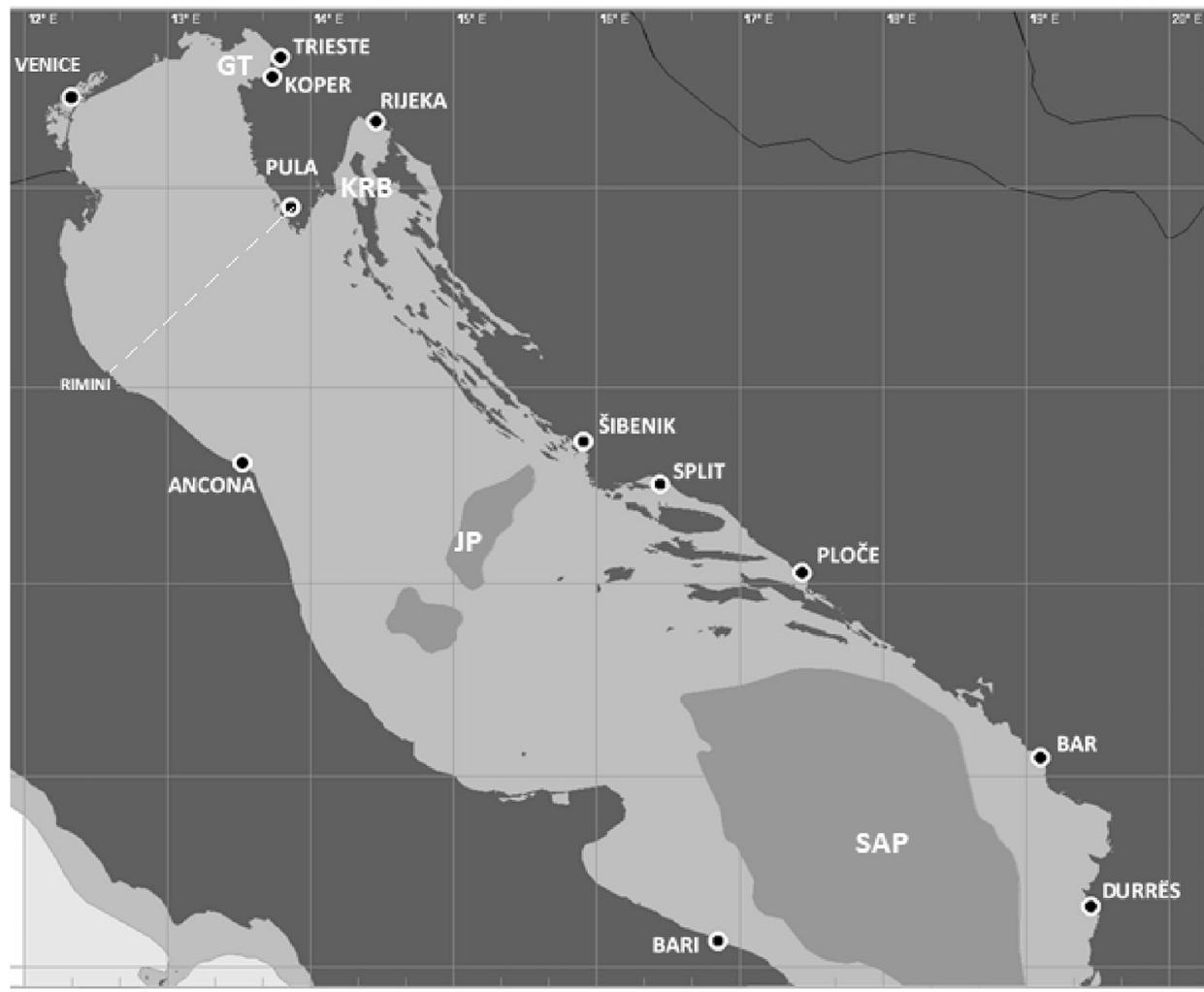

Fig. 1. Map of the Adriatic Sea showing the 12 ports selected for Port Baseline Surveys (Durrës, Bar, Ploče, Split, Šibenik, Rijeka, Pula, Koper, Trieste, Venice, Ancona, and Bari); the Northern Adriatic area is located north to the dotted line joining Pula to Rimini; GT: Gulf of Trieste; KRB: Kvarner and Rijeka Bay; JP: Jabuka Pit; SAP: South Adriatic Pit. 
Table 1a

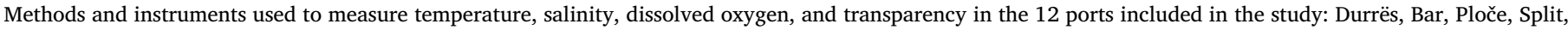
Šibenik, Pula, Rijeka, Koper, Trieste, Venice, Ancona, and Bari.

\begin{tabular}{|c|c|c|c|c|}
\hline Port & Temperature & Salinity & Dissolved oxygen & Transparency \\
\hline Durrës & OxyGuard Handy Polaris probe & YSI 85 probe & OxyGuard Handy Polaris probe & Secchi disk \\
\hline Bar & Probe TESTO 112 & WTW cell, TetraCon 325 & $\begin{array}{l}\text { Winkler (1888) method modified by Strickland and } \\
\text { Parsons (1972) }\end{array}$ & Secchi disk \\
\hline Ploče & $\begin{array}{l}\text { WTW-Cond } 3110 \text { Set } 2 \text { probe or OxyGuard Handy } \\
\text { Polaris probe }\end{array}$ & $\begin{array}{l}\text { WTW-Cond } 3110 \text { Set } 2 \text { probe or YSI } \\
85 \text { probe }\end{array}$ & OxyGuard Handy Polaris probe & Secchi disk \\
\hline Split Šibenik & SBE 25 Sealogger CTD & SBE 25 Sealogger CTD & Winkler method (Grasshoff, 1976) & Secchi disk \\
\hline Pula Rijeka & SBE 25 Sealogger CTD & SBE 25 Sealogger CTD & Winkler method (Parsons et al., 1984) & Secchi disk \\
\hline Koper & CTD probe (Sea \& Sun Technology GmbH) & $\begin{array}{l}\text { CTD probe (Sea \& Sun Technology } \\
\text { GmbH) }\end{array}$ & CTD probe (Sea \& Sun Technology GmbH) & Secchi disk \\
\hline Trieste & SBE 16plus V2 & SBE 16plus V2 & SBE 16plus V2 & Secchi disk \\
\hline Venice & SBE 19plus V2 & SBE 19plus V2 & SBE 19plus V2 & Secchi disk \\
\hline Ancona & SBE 911plus CTD & SBE 911plus CTD & Not measured & Not measured \\
\hline Bari & SBE 19plus V2 & SBE 19plus V2 & SBE 19plus V2 & Secchi disk \\
\hline
\end{tabular}

Stations were defined as INport $(n=39)$ or OUTport $(n=17)$ according to their location inside or outside the port. Although the distinction was mostly straightforward, stations located on the imaginary line closing the port were considered as OUTport, based on the assumption that they were more affected by coastal processes than by port circulation patterns. Further details on stations are reported in the paper by Kraus et al. (this issue).

Station depth ranged from 3.5 to $57.2 \mathrm{~m}$; accordingly, stations were divided in relation to depth into shallow (3.5-9.9 m), intermediate (10-19.9 m), and deep (20.0-57.2 m).

Sampling frequency varied among ports and in some cases also among stations. The list of sampling dates is reported in Table 2. The seasons were defined as follows: winter (w; 1 December-28 February), spring (sp; 1 March-31 May), summer (su; 1 June-31 August) and autumn (a; 1 September-30 November). Further details are reported in the next section.

\subsection{Data}

Given the heterogeneous sampling frequency, date, station location (INport/OUTport), and depth, the calculation of some average values was felt to enhance comparability, as follows:

"s": a single, average value of all surface data (depth range 0-1.5 m) collected at each INport and OUTport station was calculated for temperature, salinity, total inorganic nitrogen (TIN), orthophosphates $\left(\mathrm{PO}_{4}\right)$, orthosilicates $\left(\mathrm{SiO}_{4}\right)$ and chlorophyll $a(\mathrm{Chl} a)$ for each cruise (Table 2), which usually involved a single day (occasionally two; Suppl. Table 1);

"a": a single, average value of the water column data collected at each INport and OUTport station was calculated for temperature, salinity, transparency, TIN, $\mathrm{PO}_{4}, \mathrm{SiO}_{4}$ and $\mathrm{Chl} a$ for each cruise (Suppl. Table 1).

The approximation of the water column was done as follows: if values were obtained at $0 \mathrm{~m}, 5 \mathrm{~m}$, and $10 \mathrm{~m}$ at a sampling station lying at a depth of $12 \mathrm{~m}$, then the value measured at $0 \mathrm{~m}$ was applied to the $0-2.5 \mathrm{~m}$ layer, the value measured at $5 \mathrm{~m}$ was applied to the $2.5-7.5 \mathrm{~m}$ layer, and the value sampled at $10 \mathrm{~m}$ was applied to the 7.5-12 $\mathrm{m}$ layer.

"a" values were then computed using the formula:

$a=\left(p_{0} \cdot 2.5+p_{5} \cdot 5.0+p_{10} \cdot 4.5\right) / 12$; where $p_{i}$ was the value of $p$ at depth 0,5 , or $10 \mathrm{~m}$;

- "s/a" was the ratio of "s" to "a"

- "sTIN $/ \mathrm{SPO}_{4}$ " in port and in adjacent open water were calculated based on the "sTIN" and "sPO ${ }_{4}$ " values measured in the INport or OUTport stations of each port;

- "aTIN/ $\mathrm{aPO}_{4}$ " and "aSiO 4 /aTIN" in port and in adjacent open water were calculated using the "aTIN", "aPO ${ }_{4}$ " or "aSiO ${ }_{4}$ " values measured in the INport or OUTport stations of each port;

- "Transp" was the ratio of a measured Secchi depth value to station depth (for stations found in shallow water) or to a fixed value of $10 \mathrm{~m}$ irrespective of water column depth (for intermediate and deep sampling stations), expressed as a percentage. A Secchi depth value $>10 \mathrm{~m}$ corresponded to $>100 \%$, i.e. very good transparency.

Table 1b

Methods and instruments used to measure nitrate $\left(\mathrm{NO}_{3}\right)$, nitrite $\left(\mathrm{NO}_{2}\right)$, ammonia $\left(\mathrm{NH}_{4}\right)$, orthophosphate $\left(\mathrm{PO}_{4}\right)$, orthosilicate $\left.(\mathrm{SiO})_{4}\right)$, and total nitrogen $(\mathrm{TIN})$ concentrations in the 12 ports included in the study: Durrës, Bar, Ploče, Split, Šibenik, Pula, Rijeka, Koper, Trieste, Venice, Ancona, and Bari.

\begin{tabular}{|c|c|c|}
\hline \multirow[t]{2}{*}{ Port } & \multicolumn{2}{|l|}{ Nutrients } \\
\hline & Method & Parameter \\
\hline Durrës Ploče & $\begin{array}{l}\text { Spectrophotometry (SECOMAM Uvi Light PC } 2 \text { Nova } \\
\text { Analytics company, Ales) }\end{array}$ & $\begin{array}{l}\mathrm{NO}_{3} \text { (Bower and Holm-Hansen, 1980a), } \mathrm{NH}_{4} \text { (Bower and Holm-Hansen, 1980b), } \mathrm{NO}_{2} \text { and } \mathrm{PO}_{4} \\
\text { (Strickland and Parsons, 1968); } \mathrm{SiO}_{4} \text {, TIN: not determined }\end{array}$ \\
\hline Bar & Spectrophotometry (UV/VIS, Analytic Jena) & $\mathrm{NO}_{3}, \mathrm{NO}_{2}, \mathrm{PO}_{4}, \mathrm{SiO}_{4}$ and TIN (Strickland and Parsons, 1972); $\mathrm{NH}_{4}:$ not determined \\
\hline Split Šibenik & Colorimetry (AutoAnalyzer, Seal Analytical) & $\mathrm{NO}_{3}, \mathrm{NO}_{2}$ and $\mathrm{NH}_{4}, \mathrm{PO}_{4}, \mathrm{SiO}_{4}$ and TIN (Grasshoff, 1976) \\
\hline Pula Rijeka & Spectrophotometry (Shimadzu UV-Mini 1240) & $\mathrm{NO}_{3}, \mathrm{NO}_{2}, \mathrm{PO}_{4}, \mathrm{SiO}_{4}$ (Parsons et al., 1984), $\mathrm{NH}_{4}$ (Ivančić and Degobbis, 1984); TIN: not determined \\
\hline Koper & Colorimetry (Autoanalyzer QuAAtro, Seal Analytical) & $\mathrm{NO}_{3}, \mathrm{NO}_{2}$ and $\mathrm{NH}_{4}, \mathrm{PO}_{4}, \mathrm{SiO}_{4}$ and TIN (Grasshoff et al., 1999) \\
\hline Trieste & $\begin{array}{l}\text { Colorimetry (QuAAtro Continuous Flow Analyzer, Seal } \\
\text { Analytical) }\end{array}$ & $\mathrm{NO}_{3}, \mathrm{NO}_{2}$ and $\mathrm{NH}_{4}, \mathrm{PO}_{4}, \mathrm{SiO}_{4}$ (Hansen and Koroleff, 1999); TIN: not determined \\
\hline Venice & Colorimetry (Flow-Solution III Autoanalyzer OI-Analytical) & $\mathrm{NO}_{3}, \mathrm{NO}_{2}, \mathrm{NH}_{4}$, reactive silicate and phosphorus (Grasshoff et al., 1999); TIN: not determined \\
\hline Ancona & Colorimetry (Axflow QUAATRO autoanalyzer) & $\mathrm{NO}_{3}, \mathrm{NO}_{2}, \mathrm{NH}_{4}, \mathrm{PO}_{4}, \mathrm{SiO}_{4}$ (Parsons et al., 1984); TIN: not determined \\
\hline Bari & Colorimetry (Autoanalyzer 3, Bran + Luebbe, Norderstedt) & $\mathrm{NO}_{3}, \mathrm{NO}_{2}, \mathrm{NH}_{4}, \mathrm{PO}_{4}, \mathrm{SiO}_{4}$ (Bran + Luebbe, 2004), TIN (Grasshoff et al., 1999) \\
\hline
\end{tabular}


Table 1c

Methods and instruments used to measure chlorophyll $a$ as a proxy of phytoplankton biomass in the 12 ports involved in the study. Venice: CTD probe; Bari, Koper, Pula, Rijeka, Split, and Šibenik: fluorometry; Bar and Trieste: spectrofluorometry; Ancona, Durrës and Ploče: not determined. Samples for fluorometric and spectrofluorometric determinations were collected using a $5 \mathrm{~L}$ Niskin bottle and filtered through Whatman GF/F or GF/C glass-fibre filters; filters were stored at $-20^{\circ} \mathrm{C}$ until analysis, when pigments were extracted for $2-8 \mathrm{~h}$ in dark $\left(4^{\circ} \mathrm{C}\right)$ with $90 \%$ acetone prior to measurements.

\begin{tabular}{lll}
\hline Port & Chlorophyll $a$ & \\
\cline { 2 - 3 } & Instrument & Jeffrey et al., 1997 \\
Bar & SF (Analytic Jena spectrophotometer) & Specchiulli et al. (2016), EPA 445.0 (1997) \\
Bari & F (Trilogy LaBoratory Fluorimeter, Turner Designs, V. 1.2) & Holm-Hansen et al. (1965), EPA 445.0 (1997) \\
$\begin{array}{ll}\text { Koper } \\
\text { Pula Rijeka }\end{array}$ & F (Trilogy Fluorometer, Turner Designs) & Parsons et al., 1984 \\
Split Šibenik & F (Farrand F-4 fluorometer) & Lorenzen and Jeffrey, 1980 \\
$\begin{array}{l}\text { Trieste } \\
\text { Venice }\end{array}$ & SF (LaBoratory Fluorometer Turner TD-700) & \\
\hline
\end{tabular}

F: fluorometry; SF: spectrofluorometry.

The difference in water density due to temperature and salinity was arbitrarily chosen to quantify the barrier effect, if any, exerted by the two parameters on HAOP spread from INport to OUTport areas, as follows:

$\mathrm{d}_{\text {INs }} ; \mathrm{d}_{\text {OUTs }}$ : average surface density calculations in a month at INport and OUTport stations.

$\mathrm{d}_{\text {INa; }}$; $\mathrm{d}_{\text {OUTa }}$ : average of the density averages (see the definition of "a") calculated for each metre of the water column over a month at INport and OUTport stations.

$\left(\mathrm{d}_{\text {Ins }}-\mathrm{d}_{\text {OUTs }}\right) \leq-1$ and $\left(\mathrm{d}_{\text {Ins }}-\mathrm{d}_{\text {OUTs }}\right) \geq 1$ corresponded to a barrier effect occurring between INport and OUTport stations on the surface layer.

$\left(\mathrm{d}_{\text {Ina }}-\mathrm{d}_{\text {OUTa }}\right) \leq-1$ and $\left(\mathrm{d}_{\text {Ina }}-\mathrm{d}_{\text {OUTa }}\right) \geq 1$ corresponded to a barrier effect occurring between INport and OUTport stations throughout the water column.

Hourly weather report records and model reconstructions were used to obtain seasonal average wind intensity and direction information for the period from January 1980 to December 2016 (WeatherSpark.com, accessed on 19 July 2018).

\subsection{Numerical modelling}

Sea currents were measured synchronically using an Acoustic Doppler Current Profiler (ADCP) at the main entrances to KRB for 12 months, to evaluate inflow/outflow dynamics in the bay (Fig. 1). These data provided a framework to evaluate water residence time and a benchmark for the numerical model estimates.

Measurements were taken from September/October 2014 to September/October 2015. Sampling frequency was $15 \mathrm{~min}$; vertical resolution was $1 \mathrm{~m}$ or $2 \mathrm{~m}$, depending on station depth. Temperature and salinity, sampled with a Conductivity-Temperature-Depth (CTD) probe at the same time frequency, allowed calculating bottom water density.

A numerical simulation of the Adriatic Sea circulation was performed based on realistic atmospheric forcing data provided at $3 \mathrm{~h}$ intervals by the ALADIN operational model of the Croatian Meteorological Service and on daily Mediterranean model boundary conditions. This system is based on the ROMS model, which provides a horizontal resolution of $2 \mathrm{~km}$ and 20 vertical levels (Janeković et al., 2010) with additional nested high-resolution sub-domains of $500 \mathrm{~m}$ resolution for KRB and the mid-Adriatic region (Figs. 2-4). The model was integrated from October 2014 to November 2015, providing a year of 3D modelled fields that were saved every $3 \mathrm{~h}$. The mean circulation for all modelling domains was computed based on season: winter (1 December-28 February), spring (1 March-31 May), summer (1 June-31 August) and autumn (1 September-30 November).

The ROMS model output on the 3 grids was combined and interpolated on unstructured grids covering the Adriatic. HAOP spread was simulated using tracers that mimic species spread (Figs. 5-15) and modelled based on surface currents and currents at a depth of $25 \mathrm{~m}$. The unstructured grid model used the N-scheme for advection and a Tomaich diffusion scheme for diffusion. Preliminary data analysis demonstrated that diffusion did not significantly affect spread. The run was from 2014-07-01 to 2015-06-01. Due to technical difficulties, spread simulations were not performed for the port of Šibenik. The tracers were continuously released at a location in or near the port over the whole range of the run. For each cruise, the analysis regarded the maximum tracer concentration in a 30-day period, 15 days before and 15 days after the cruise. Despite continuous release, the tracer did not accumulate and was eventually absorbed at the boundary.

\section{Results}

\subsection{Port environment}

To gain insight into the environmental conditions found in ports (INport stations) and in adjacent open sea areas (OUTport stations), averaged seasonal values were calculated for the main oceanographic parameters (Table 3). The complete dataset is reported in Supplementary Table 1.

The temperature was generally higher at INport than OUTport stations except in winter, when the INport surface layer was colder. In autumn, the surface temperature was similar to the average temperature of the water column, indicating that in this season the water column was mixed both at INport and OUTport stations. The surface layer was colder than the average water column temperature in winter in port and warmer in spring and summer in open sea areas, whereas the water column was mixed in winter in OUTport areas and in spring and summer in INport areas. Salinity was lower in port at all times; moreover, in winter and summer it was lower in the surface layer than in the entire water column, whereas in spring and autumn the water column was mixed at all stations.

Nutrient concentrations were generally higher in port at all times and were highest in the surface layer. However, a high P-limitation was found throughout the study area (TIN/ $\mathrm{PO}_{4}>16$ ): in the surface layer, it was more marked at OUTport than INport stations, whereas in the water column it was higher in spring, summer, and autumn in INport areas and higher in winter in OUTport areas. The Si-limitation was confined to the port area in winter and, especially, spring $\left(\mathrm{SiO}_{4} /\right.$ TIN < 1). Phytoplankton biomass production, estimated as Chl $a$ concentration, was higher in winter, spring, and summer in port, and higher in the surface layer than in the water column. In autumn, surface production was higher outside the port, whereas production in the water column was still higher in port. 
Table 2

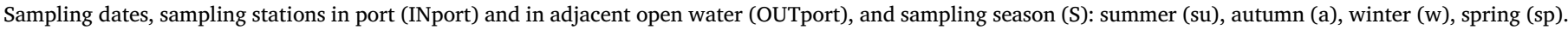

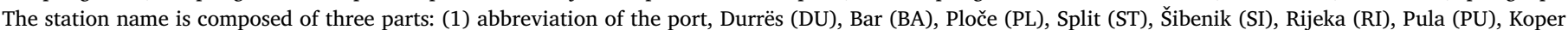

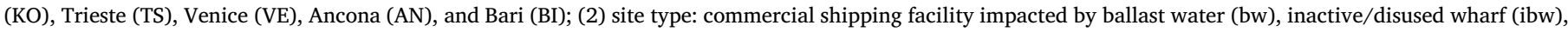

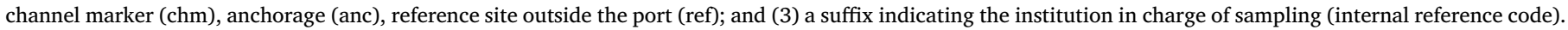
n.a. = not available.

\begin{tabular}{|c|c|c|c|c|c|c|c|c|c|c|}
\hline \multirow[t]{3}{*}{ Port } & \multicolumn{8}{|c|}{ Sampling dates } & \multicolumn{2}{|c|}{ Sampling stations } \\
\hline & \multicolumn{4}{|c|}{ INport } & \multicolumn{4}{|c|}{ OUTport } & \multirow[t]{2}{*}{ INport } & \multirow[t]{2}{*}{ OUTport } \\
\hline & $\mathrm{S}$ & $\mathrm{d}$ & $\mathrm{m}$ & $\mathrm{y}$ & $\mathrm{S}$ & $\mathrm{d}$ & $\mathrm{m}$ & $\mathrm{y}$ & & \\
\hline \multirow[t]{3}{*}{ Durrës } & su & 7 & 6 & 2014 & su & n.a. & n.a. & n.a. & DUbw1 & n.a. \\
\hline & $\mathrm{a}$ & 8 & 11 & 2014 & $\mathrm{a}$ & n.a. & n.a. & n.a. & DUbw2 & \\
\hline & $\mathrm{a}$ & 13 & 9 & 2016 & $\mathrm{a}$ & n.a. & n.a. & n.a. & DUbw3 & \\
\hline \multirow[t]{4}{*}{ Bar } & $\mathrm{w}$ & 11 & 2 & 2015 & $\mathrm{w}$ & 11 & 2 & 2015 & BAbw1 & BAref \\
\hline & $\mathrm{sp}$ & 15 & 4 & 2015 & $\mathrm{sp}$ & 15 & 4 & 2015 & BAbw2 & \\
\hline & su & 23 & 6 & 2015 & su & 23 & 6 & 2015 & BAibw3 & \\
\hline & $\mathrm{a}$ & 26 & 10 & 2015 & $\mathrm{a}$ & 26 & 10 & 2015 & & \\
\hline \multirow[t]{4}{*}{ Ploče } & $\mathrm{sp}$ & 13 & 5 & 2011 & $\mathrm{sp}$ & n.a. & n.a. & n.a. & PLbwKV & n.a. \\
\hline & su & 21 & 7 & 2011 & su & n.a. & n.a. & n.a. & PLbw1 & \\
\hline & $\mathrm{a}$ & 11 & 10 & 2011 & $\mathrm{a}$ & n.a. & n.a. & n.a. & PLbw3 & \\
\hline & $\mathrm{sp}$ & 18 & 5 & 2016 & $\mathrm{sp}$ & n.a. & n.a. & n.a. & PLbw5 & \\
\hline \multirow[t]{5}{*}{ Split } & $\mathrm{sp}$ & 28 & 4 & 2011 & $\mathrm{sp}$ & n.a. & n.a. & n.a. & STbwJ1 & n.a. \\
\hline & su & 12 & 7 & 2011 & su & n.a. & n.a. & n.a. & STbwK1 & \\
\hline & $\mathrm{a}$ & 5 & 10 & 2011 & $\mathrm{a}$ & n.a. & n.a. & n.a. & STbwL1 & \\
\hline & $\mathrm{sp}$ & 23 & 4 & 2014 & $\mathrm{sp}$ & n.a. & n.a. & n.a. & STbwL2 & \\
\hline & su & 24 & 8 & 2014 & su & n.a. & n.a. & n.a. & & \\
\hline \multirow[t]{4}{*}{ Šibenik } & w & 18 & 12 & 2013 & w & n.a. & n.a. & n.a. & SIbw1 & n.a. \\
\hline & $\mathrm{sp}$ & 24 & 4 & 2014 & $\mathrm{sp}$ & n.a. & n.a. & n.a. & SIbw2 & \\
\hline & su & 26 & 8 & 2014 & su & n.a. & n.a. & n.a. & SIbw3 & \\
\hline & $\mathrm{w}$ & 12 & 12 & 2014 & $\mathrm{w}$ & n.a. & n.a. & n.a. & & \\
\hline \multirow[t]{6}{*}{ Rijeka } & $\mathrm{a}$ & 11 & 9 & 2014 & $\mathrm{a}$ & 10,11 & 9 & 2014 & RIbwB & RIref \\
\hline & $\mathrm{w}$ & 20 & 12 & 2014 & $\mathrm{w}$ & 19,20 & 12 & 2014 & RIbwS & RIchm \\
\hline & $\mathrm{w}$ & 13 & 2 & 2015 & $\mathrm{w}$ & 12,13 & 2 & 2015 & & \\
\hline & $\mathrm{sp}$ & 24 & 4 & 2015 & $\mathrm{sp}$ & 23,24 & 4 & 2015 & & \\
\hline & su & 14 & 7 & 2015 & su & 14 & 7 & 2015 & & \\
\hline & $\mathrm{a}$ & 11 & 11 & 2015 & $\mathrm{a}$ & 10,11 & 11 & 2015 & & \\
\hline \multirow[t]{6}{*}{ Pula } & $\mathrm{a}$ & 9 & 9 & 2014 & $\mathrm{a}$ & 9 & 9 & 2014 & PUbwC & PUref \\
\hline & $\mathrm{w}$ & 18 & 12 & 2014 & $\mathrm{w}$ & 18 & 12 & 2014 & PUbwS & \\
\hline & w & 11 & 2 & 2015 & w & 11 & 2 & 2015 & PUchm & \\
\hline & $\mathrm{sp}$ & 6 & 5 & 2015 & $\mathrm{sp}$ & 6 & 5 & 2015 & & \\
\hline & su & 16 & 7 & 2015 & su & 16 & 7 & 2015 & & \\
\hline & $\mathrm{a}$ & 9 & 11 & 2015 & $\mathrm{a}$ & 9 & 11 & 2015 & & \\
\hline Koper & $\mathrm{sp}$ & 9 & 5 & 2014 & $\mathrm{sp}$ & 9 & 5 & 2014 & KObw1 & KOanc4 \\
\hline & su & 28 & 7 & 2014 & su & 28 & 7 & 2014 & KObw2 & \\
\hline & $\mathrm{a}$ & 17 & 11 & 2014 & $\mathrm{a}$ & 17 & 11 & 2014 & KObw3 & \\
\hline & w & 9 & 2 & 2015 & w & 9 & 2 & 2015 & & \\
\hline Trieste & $\mathrm{sp}$ & 12 & 5 & 2014 & $\mathrm{sp}$ & 12,15 & 5 & 2014 & TSbw1 & TSchm7 \\
\hline & su & 30 & 6 & 2014 & su & 12,30 & 6 & 2014 & TSbw2 & TSrefC1 \\
\hline & $\mathrm{a}$ & 23 & 9 & 2014 & $\mathrm{a}$ & 18,23 & 9 & 2014 & TSbw3 & \\
\hline & $\mathrm{w}$ & 27 & 1 & 2015 & w & 19,27 & 1 & 2015 & TSbw4 & \\
\hline & & & & & & & & & TSbwM & \\
\hline Venice & $\mathrm{sp}$ & 25 & 3 & 2014 & $\mathrm{sp}$ & 25 & 3 & 2014 & VEbw7M & VEancPTF \\
\hline & $\mathrm{sp}$ & 20 & 5 & 2014 & $\mathrm{sp}$ & 20 & 5 & 2014 & VEbwIN & VErefS1 \\
\hline & su & 8 & 8 & 2014 & su & 8 & 8 & 2014 & VEbwP1 & VErefS2 \\
\hline & $\mathrm{a}$ & 21 & 10 & 2014 & $\mathrm{a}$ & 21 & 10 & 2014 & VEbwW2 & VErefW4 \\
\hline & $\mathrm{w}$ & 11 & 2 & 2015 & $\mathrm{w}$ & 11 & 2 & 2015 & VEbwW3 & \\
\hline Ancona & $\mathrm{sp}$ & 28 & 3 & 2014 & $\mathrm{sp}$ & 18 & 3 & 2014 & ANbwDS & ANancAPI \\
\hline & sp & 8 & 5 & 2014 & $\mathrm{sp}$ & 24 & 5 & 2014 & ANbwLR & ANancMB \\
\hline & su & 27 & 8 & 2014 & su & 22 & 8 & 2014 & & ANrefSL1 \\
\hline & $\mathrm{a}$ & 27 & 10 & 2014 & $\mathrm{a}$ & 29 & 10 & 2014 & & ANrefSL2 \\
\hline & $\mathrm{w}$ & 17 & 2 & 2015 & $\mathrm{w}$ & 13 & 2 & 2015 & & \\
\hline Bari & $\mathrm{sp}$ & 20 & 3 & 2014 & $\mathrm{sp}$ & 20 & 3 & 2014 & BIbw1 & BIref4 \\
\hline & $\mathrm{sp}$ & 26 & 5 & 2014 & sp & 26 & 5 & 2014 & BIbw2 & BIref8 \\
\hline & su & 5 & 8 & 2014 & $\mathrm{a}$ & 10 & 9 & 2014 & & \\
\hline & $\mathrm{a}$ & 5 & 11 & 2014 & $\mathrm{a}$ & 4 & 11 & 2014 & & \\
\hline & w & 19 & 2 & 2015 & w & 19 & 2 & 2015 & & \\
\hline
\end{tabular}




\subsection{Ports and adjacent open sea}

HAOP were assumed to be holoplankton species, such as bacterioplankton, phytoplankton, zooplankton, and meroplankton in early life stages (eggs and larvae), which are predominantly spread by currents and water circulation. The investigation of the potential HAOP spread from ports to the adjacent open sea was based on multiple types of information which included facts, estimations, and measured data. Notably, the lack of port data (e.g. currents, diffusion and sedimentation rates), which would have allowed drawing reliable conclusions or at least scientifically supported assumptions, involved that possible scenarios could be sketched only based on the educated guess principle. The following facts were entered: geographic position of the port (deep inland in a narrow bay versus coastline location), depth of the sampling station (Suppl. Table 1), and port openness (closed ports being those with long enclosing breakwaters or natural barriers like the Venetian lagoon). Estimations included the type of basin ("dilution" or "concentration", involving the spread of surface or bottom water from the port to the open sea, respectively) and the barrier effect between port and open sea based on temperature and salinity. Measured data included the average intensity and direction of the prevailing winds. Detailed geographic position and openness data are reported in the paper by Kraus et al. (this issue).

As regards the type of port, a simple concept based on surface salinity was adopted to characterise ports as dilution or concentration basins. When water salinity is lower in the INport area than outside, low-salinity surface water flows out of the basin and is compensated for by an inflow of deep layer water, giving rise to a dilution basin; when salinity is lower in the open sea, the inflow of less saline water is on the surface and the outflow is in the bottom layer, a phenomenon that gives rise to a concentration basin. An arbitrary value of 0.1 was adopted to distinguish "same" from "different" salinity values. Out of 38 situations analysed in the study period in 8 ports, there were 28 cases of a dilution basin, only 9 of a concentration basin, and a single "neutral" situation (Table 4). The ports of Koper and Venice were dilution basins, whereas Ancona, Bar, Bari, Pula, Rijeka, and Trieste were always mixed-type basins. None of the ports were concentration basins in all cases. The widest salinity difference (from -9.89 to 1.57 ) was determined in Rijeka. The highest salinity difference, indicating a dilution basin event, was measured in Rijeka (-9.89) in winter and the one indicating a concentration basin was seen in Ancona (3.31) in spring. The ranges observed in concentration basins were 0.14-1.13 in winter, 1.03-3.31 in spring, and 0.18-1.57 in autumn (a single measurement was taken in summer, 2.17), whereas those measured in dilution basins were 0.43-9.89 in winter, 0.32-4.98 in spring, 0.33-6.49 in summer, and $0.24-3.39$ in autumn.

The assessment of the presence/absence of a barrier effect between an INport and an OUTport station was based on the difference in water density, i.e. the difference in temperature and salinity, between them (Table 5). The absence of a barrier effect involves the probable outflow and mixing of port and open sea water, therefore HAOP are less likely to be retained in port; in contrast, the presence of a barrier effect involves a longer retention of HAOP in port due to a pronounced density difference between port and open sea water. The density difference was calculated in each season both in the surface layer and in the whole water column. In Bar, the barrier effect seemed to be absent, whereas in Venice it was consistently present in the surface layer, the water column, or both.

According to the average seasonal intensity and direction of the winds - based on a statistical analysis of historical hourly weather reports and model reconstructions from January 1980 to December 2016 - wind intensity is lower (5-7 mph) in the ports of Koper, Trieste, and Venice and higher in those of Ancona and Bari (up to $12 \mathrm{mph}$ ). Whereas easterly winds are predominant in most ports, in Ancona, Bari, and Durrës they come from other directions (Table 6).

Assessment of the potential spread of HAOP was based on the facts, measurements, and estimations described above. Analysis of these data allowed to outline the following scenarios.

The port of Durrës is moderately deep $(8-10 \mathrm{~m})$ and is enclosed by breakwaters; its connection with the open sea is in the south-eastern area, and it is fairly narrow. The lack of data for this port involved that only wind information was available. In this port the winds are characterized by a variable direction and intensity. In autumn, winter, and spring, moderate to strong southerly and easterly winds very likely favour water inflow from the open sea and downwelling of surface water, which result in HAOP retention and sinking in port. In contrast, the westerly summer winds may determine surface outflow; their low intensity may be insufficient to induce outflow, but they can favour mild mixing of the surface layer and HAOP retention.

In the port of Bar, which is moderately deep (10-12 m) and enclosed by breakwaters, the fairly narrow connection with the open sea is in the northern area. The prevailing winds are easterly. The water column was stratified in winter (colder surface layer) as well as in spring and summer (warmer surface layer), whereas in autumn it was both mixed and stratified due to a warmer or a cooler surface layer. No barrier effect was present in any season. In spring, the basin was of the concentration type, favouring sinking; therefore, moderate winds are likely to induce HAOP retention if the surface layer undergoes mixing. In autumn, winter, and summer, the basin was of the dilution type, favouring outflow. Moderate winds in autumn and weak winds in summer are likely to induce surface outflow, whereas in winter the cold surface water, which is probably further cooled by strong winds, is even more likely to induce surface outflow.

The stations established in the port of Ploče lay along the narrow canal and in the bay, which hamper the connection to the open sea. The port is moderately deep (9-15 m). Again, the scenario was based only on the winds, which are predominantly easterly and likely to induce water outflow, albeit indirectly. The water column was mixed or showed a warmer surface layer in spring (data for the other seasons are not available). In winter and spring, when the water column is mixed, strong winds are likely to favour vertical mixing and HAOP retention. In summer, the stratified water column and weak winds probably induce slight mixing of the surface layer and HAOP retention. In autumn, when the water column is very likely mixed or slight stratified, moderately intense winds may induce surface outflow and HAOP spread from the port. However, given the configuration of the port, the outflow is probably limited.

The port of Split is moderately deep (10-17 m). Since it is open, the sampling stations were established around the bay. Due to lack of data, the information available to sketch the scenario regarded only the (mostly easterly) winds. In autumn, the water column was mixed (as it most probably was in winter), and in strong wind conditions it may determine vertical mixing and HAOP sinking. In spring and summer, the water column was stratified. In spring, strong winds probably favour surface outflow; in summer, low-intensity winds may only induce surface mixing (and HAOP retention).

The port of Šibenik is deep (15-33 m) and lies in a narrow bay deep inland. Only wind data were available for this port. Winds are mostly easterly except in summer, when northerly winds also blow. In autumn, the water column is probably mixed, and strong easterly winds probably favour further vertical mixing and HAOP retention and sinking. In winter, the water column was stratified, due to a colder surface layer, and very strong easterly winds may determine surface water outflow towards the sea. In spring and summer the water column was stratified, due to a warmer surface. In spring, strong easterly wind can cool the surface and induce vertical mixing and HAOP retention and sinking. In summer, the low-intensity easterly and northerly winds involve that HAOP probably remain in the bay.

The port of Rijeka consists of two shallow areas (7-9 m), both enclosed by breakwaters; its connections with the open sea are in the western area, and are fairly narrow. It is characterized by low-moderate easterly winds, which blow the water out to sea. In autumn, when the 


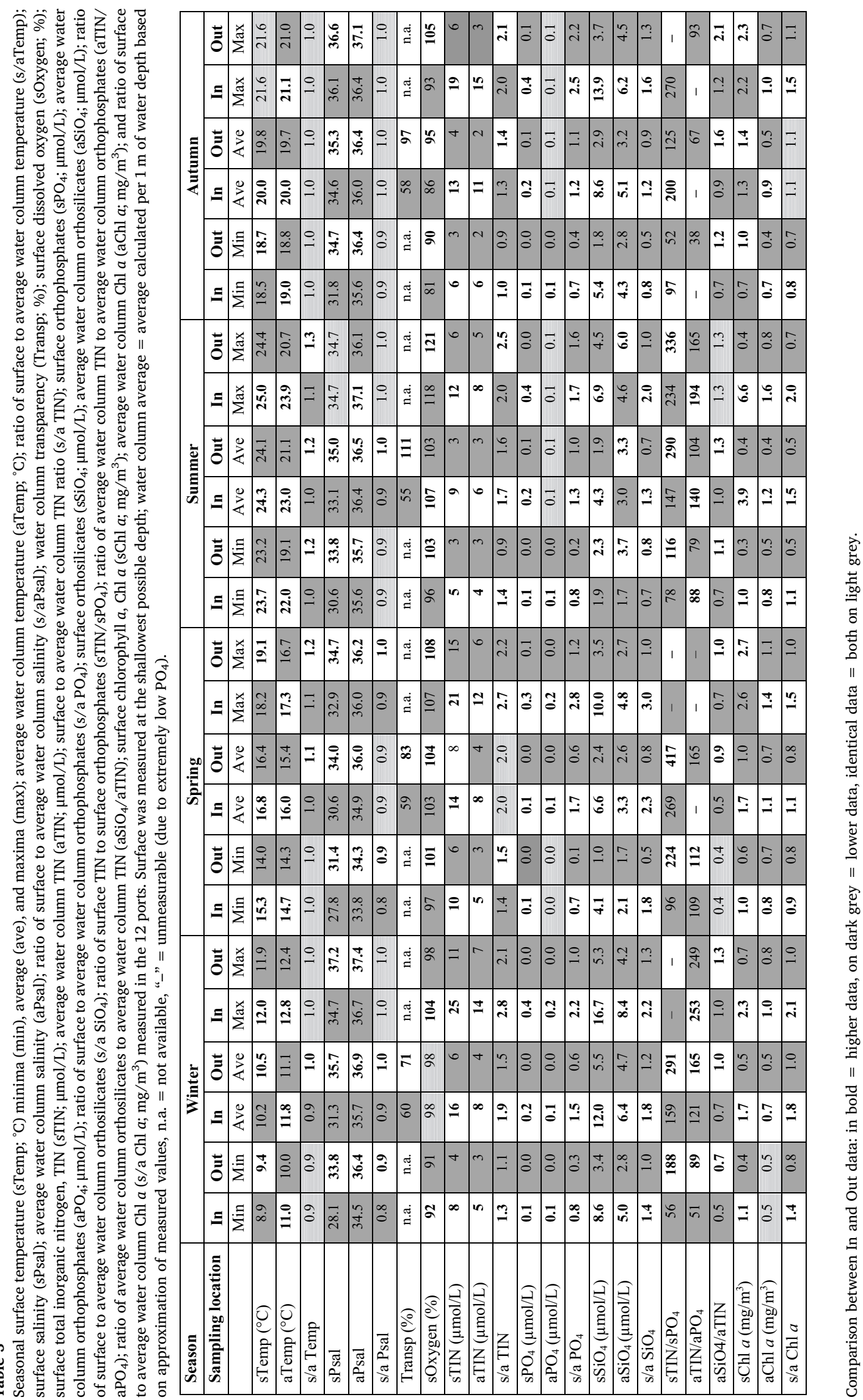


Table 4

Average INport and OUTport surface temperature (INsurfT and OUTsurfT; ${ }^{\circ} \mathrm{C}$ ) and salinity (INportS and OUTsurfS) measured at the shallowest possible depth (S. depth) in eight ports (Bar, Rijeka, Pula, Koper, Trieste, Venice, Ancona, and Bari); difference in salinity values between INport and OUTport station (surfSdiff); and basin type, i.e. dilution (D, white lines), concentration (C, grey lines), and undetermined (“-”, dark grey line).

\begin{tabular}{|c|c|c|c|c|c|c|c|c|c|c|c|c|c|}
\hline Port & Day & Month & Year & Season & S. depth (m) & Temp. $\left({ }^{\circ} \mathrm{C}\right)$ & Salinity & INsurfT & OUTsurfT & INsurfS & OUTsurfS & surfSdiff & Basin type \\
\hline Bar & 26 & 10 & 2015 & $\mathrm{a}$ & 0.5 & 20.60 & 31.70 & 21.07 & 21.00 & 32.17 & 32.70 & -0.53 & $\mathrm{D}$ \\
\hline Bar & 15 & 4 & 2015 & $\mathrm{sp}$ & 0.5 & 16.30 & 36.80 & 17.30 & 16.20 & 36.43 & 35.40 & 1.03 & $\mathrm{C}$ \\
\hline Bar & 23 & 6 & 2015 & su & 0.5 & 22.20 & 36.50 & 22.20 & 23.30 & 36.77 & 37.10 & -0.33 & $\mathrm{D}$ \\
\hline Bar & 11 & 2 & 2015 & $\mathrm{w}$ & 0.5 & 11.60 & 31.90 & 11.53 & 11.70 & 32.27 & 32.70 & -0.43 & $\mathrm{D}$ \\
\hline Rijeka & 11 & 9 & 2014 & $\mathrm{a}$ & 0.0 & 19.01 & 33.48 & 17.41 & 19.86 & 34.15 & 32.58 & 1.57 & $\mathrm{C}$ \\
\hline Rijeka & 11 & 11 & 2015 & $\mathrm{a}$ & 0.0 & 13.54 & 33.22 & 13.22 & 15.31 & 30.83 & 33.95 & -3.12 & $\mathrm{D}$ \\
\hline Rijeka & 24 & 4 & 2015 & $\mathrm{sp}$ & 0.0 & 13.15 & 36.24 & 12.67 & 13.89 & 35.98 & 36.30 & 0.32 & $\mathrm{D}$ \\
\hline Rijeka & 14 & 7 & 2015 & su & 0.0 & 20.29 & 35.30 & 19.63 & 23.43 & 32.29 & 36.45 & -4.17 & $\mathrm{D}$ \\
\hline Rijeka & 13 & 2 & 2015 & $\mathrm{~W}$ & 0.0 & 9.46 & 31.58 & 9.23 & 11.13 & 27.23 & 37.11 & -9.89 & $\mathrm{D}$ \\
\hline Rijeka & 20 & 12 & 2014 & $\mathrm{w}$ & 0.0 & 13.06 & 31.45 & 12.45 & 13.10 & 27.86 & 32.82 & -4.96 & $\mathrm{D}$ \\
\hline Pula & 9 & 9 & 2014 & $\mathrm{a}$ & 0.0 & 23.39 & 36.94 & 23.67 & 22.31 & 36.83 & 37.40 & -0.57 & $\mathrm{D}$ \\
\hline Pula & 9 & 11 & 2015 & $\mathrm{a}$ & 0.0 & 17.31 & 37.60 & 17.21 & 17.57 & 37.60 & 38.21 & -0.61 & $\mathrm{D}$ \\
\hline Pula & 6 & 5 & 2015 & $\mathrm{sp}$ & 0.0 & 15.48 & 37.47 & 15.65 & 15.27 & 37.31 & 37.66 & -0.35 & $\mathrm{D}$ \\
\hline Pula & 16 & 7 & 2015 & $\mathrm{su}$ & 0.0 & 26.63 & 36.98 & 26.67 & 25.61 & 36.89 & 36.83 & 0.06 & - \\
\hline Pula & 11 & 2 & 2015 & w & 0.0 & 10.34 & 36.41 & 10.09 & 10.34 & 36.06 & 37.65 & -1.59 & D \\
\hline Pula & 18 & 12 & 2014 & w & 0.0 & 13.50 & 33.98 & 14.67 & 15.61 & 36.07 & 37.46 & -1.39 & $\mathrm{D}$ \\
\hline Koper & 17 & 11 & 2014 & $a$ & 0.0 & 18.10 & 36.82 & 17.10 & 17.00 & 32.17 & 35.56 & -3.39 & $\mathrm{D}$ \\
\hline Koper & 9 & 5 & 2014 & $\mathrm{sp}$ & 0.0 & 18.50 & 31.83 & 18.40 & 17.40 & 29.97 & 31.98 & -2.01 & $\mathrm{D}$ \\
\hline Koper & 28 & 7 & 2014 & su & 0.0 & 24.10 & 34.07 & 23.43 & 24.40 & 32.01 & 33.89 & -1.88 & $\mathrm{D}$ \\
\hline Koper & 9 & 2 & 2015 & $\mathrm{~W}$ & 0.0 & 8.90 & 37.31 & 8.60 & 8.80 & 34.61 & 37.28 & -2.67 & $\mathrm{D}$ \\
\hline Trieste & 23 & 9 & 2014 & $\mathrm{a}$ & 0.0 & 21.29 & 36.86 & 21.29 & 21.73 & 36.78 & 37.05 & -0.27 & $\mathrm{D}$ \\
\hline Trieste & 12 & 5 & 2014 & $\mathrm{sp}$ & 0.0 & 18.26 & 32.92 & 18.65 & 18.32 & 32.74 & 30.69 & 2.05 & $\mathrm{C}$ \\
\hline Trieste & 30 & 6 & 2014 & su & 0.0 & 23.36 & 32.58 & 23.47 & 22.87 & 32.65 & 33.18 & -0.53 & $\mathrm{D}$ \\
\hline Trieste & 27 & 1 & 2015 & $\mathrm{~W}$ & 0.0 & 9.80 & 36.90 & 9.43 & 9.86 & 37.03 & 36.89 & 0.14 & $\mathrm{C}$ \\
\hline Venice & 21 & 10 & 2014 & $\mathrm{a}$ & 0.0 & 21.13 & 32.26 & 22.94 & 20.86 & 31.84 & 34.04 & -2.20 & $\mathrm{D}$ \\
\hline Venice & 25 & 3 & 2014 & $\mathrm{sp}$ & 0.0 & 12.34 & 32.50 & 14.78 & 12.50 & 31.58 & 33.93 & -2.35 & $\mathrm{D}$ \\
\hline Venice & 20 & 5 & 2014 & $\mathrm{sp}$ & 0.0 & 19.70 & 29.02 & 21.64 & 20.44 & 27.59 & 30.04 & -2.45 & $\mathrm{D}$ \\
\hline Venice & 8 & 8 & 2014 & su & 0.0 & 27.50 & 27.11 & 27.58 & 24.02 & 28.17 & 34.65 & -6.49 & $\mathrm{D}$ \\
\hline Venice & 11 & 2 & 2015 & W & 0.0 & 6.23 & 32.09 & 8.31 & 7.92 & 30.51 & 36.08 & -5.57 & D \\
\hline Ancona & 27 & 10 & 2014 & $\mathrm{a}$ & 1.0 & 17.14 & 36.60 & 17.33 & 18.73 & 35.91 & 36.15 & -0.24 & $\mathrm{D}$ \\
\hline Ancona & 28 & 3 & 2014 & $\mathrm{sp}$ & 1.0 & 12.64 & 35.77 & 12.80 & 13.43 & 36.03 & 32.72 & 3.31 & $\mathrm{C}$ \\
\hline Ancona & 8 & 5 & 2014 & $\mathrm{sp}$ & 1.0 & 16.30 & 33.43 & 16.29 & 19.32 & 33.57 & 34.95 & -1.38 & $\mathrm{D}$ \\
\hline Ancona & 27 & 8 & 2014 & su & 1.5 & 26.30 & 35.29 & 26.38 & 25.13 & 35.22 & 33.04 & 2.17 & $\mathrm{C}$ \\
\hline Ancona & 17 & 2 & 2015 & w & 0.5 & 10.45 & 36.39 & 10.94 & 9.51 & 33.60 & 35.17 & -1.56 & D \\
\hline Bari & 5 & 11 & 2014 & $\mathrm{a}$ & 0.5 & 18.58 & 37.17 & 18.47 & 18.88 & 36.80 & 36.62 & 0.18 & $\mathrm{C}$ \\
\hline Bari & 20 & 3 & 2014 & $\mathrm{sp}$ & 0.6 & 13.95 & 33.98 & 14.80 & 13.98 & 30.54 & 35.52 & -4.98 & $\mathrm{D}$ \\
\hline Bari & 26 & 5 & 2014 & $\mathrm{sp}$ & 0.5 & 21.87 & 35.27 & 22.06 & 21.12 & 35.22 & 32.44 & 2.79 & $\mathrm{C}$ \\
\hline Bari & 19 & 2 & 2015 & $\mathrm{~W}$ & 0.5 & 11.26 & 33.47 & 11.34 & 10.92 & 35.81 & 34.68 & 1.13 & $\mathrm{C}$ \\
\hline
\end{tabular}

Table 5

Presence of the barrier effect between INport and OUTport stations (black dot on a grey field) in the eight ports where water density was assayed (Bar, Rijeka, Pula, Koper, Trieste, Venice, Ancona and Bari) in the surface layer and in the whole water column. n.a. = not available.

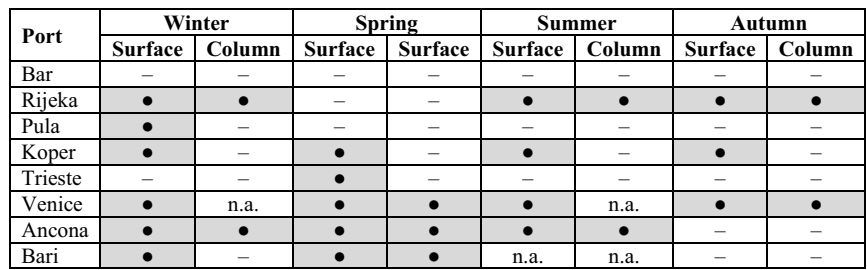

water column is stratified, a barrier effect is present; a concentration and a dilution basin were recorded on two separate occasions. Weak wind conditions probably induce either HAOP retention in the surface layer and surface outflow, presumably in relation to wind intensity. In winter, there was a stratified water column with a colder and less saline surface layer and a barrier effect throughout the water column; the dilution basin favours surface outflow and moderate wind may induce further surface cooling, hence water mixing with HAOP retention. In spring, the absence of a barrier effect and the dilution basin favoured surface outflow; weak wind may result in HAOP surface spread out of the port. In summer, despite the dilution basin - which favours surface outflow - the barrier effect, a colder surface layer, and weak wind may induce surface layer mixing and HAOP retention.

The port of Pula lies in a wide bay of shallow to moderate depth
Table 6

Average seasonal wind intensity (in $\mathrm{mph}$ ) and predominant wind direction in the 12 ports included in the study from January 1980 to December 2016. Source: WeatherSpark.com, accessed on 19 July 2018.

\begin{tabular}{|c|c|c|c|c|c|c|c|c|}
\hline \multirow[t]{2}{*}{ Port } & \multicolumn{2}{|c|}{ Winter } & \multicolumn{2}{|c|}{ Spring } & \multicolumn{2}{|c|}{ Summer } & \multicolumn{2}{|c|}{ Autumn } \\
\hline & $\mathrm{mph}$ & Direction & $\mathrm{mph}$ & Direction & $\mathrm{mph}$ & Direction & $\mathrm{mph}$ & Direction \\
\hline Durrës & 10 & $\mathrm{E}$ & 8 & $S$ & 7 & $\mathrm{~W}$ & 8 & $S, E$ \\
\hline Bar & 10 & $\mathrm{E}$ & 8 & $\mathrm{E}$ & 6 & $\mathrm{E}$ & 8 & $\mathrm{E}$ \\
\hline Ploče & 10 & $\mathrm{E}$ & 9 & $\mathrm{E}$ & 7 & $\mathrm{E}$ & 8 & $\mathrm{E}$ \\
\hline Split & 10 & $\mathrm{E}$ & 9 & $\mathrm{E}$ & 7 & $\mathrm{E}$ & 9 & $\mathrm{E}$ \\
\hline Šibenik & 11 & $\mathrm{E}$ & 9 & $\mathrm{E}$ & 7 & $\mathrm{E}, \mathrm{N}$ & 9 & $\mathrm{E}$ \\
\hline Rijeka & 8 & $\mathrm{E}$ & 6 & $\mathrm{E}$ & 5 & E & 6 & $\mathrm{E}$ \\
\hline Pula & 12 & $\mathrm{E}$ & 9 & $\mathrm{E}$ & 7 & E & 10 & $\mathrm{E}$ \\
\hline Koper & 8 & $\mathrm{E}$ & 7 & $\mathrm{E}$ & 6 & $\mathrm{E}$ & 7 & $\mathrm{E}$ \\
\hline Trieste & 7 & $\mathrm{E}$ & 6 & $\mathrm{E}$ & 5 & $\mathrm{E}$ & 7 & $\mathrm{E}$ \\
\hline Venice & 7 & $\mathrm{E}$ & 7 & $\mathrm{E}$ & 6 & $\mathrm{E}$ & 7 & $\mathrm{E}$ \\
\hline Ancona & 11 & $\mathrm{~N}$ & 9 & W & 8 & $\mathrm{~N}$ & 9 & $\mathrm{~N}$ \\
\hline Bari & 12 & $\mathrm{~N}$ & 10 & $\mathrm{~N}, \mathrm{~S}$ & 9 & $\mathrm{~N}$ & 10 & $\mathrm{~N}, \mathrm{~S}$ \\
\hline
\end{tabular}

(6-13 m) enclosed by a long breakwater. It was a dilution basin in all seasons, which is in line with the prevailing easterly winds. Strong winds likely induce surface water outflow in autumn, when the water column is stratified and surface salinity is lower (no barrier effect). Water outflow may also occur in winter, when the surface layer both in and out of the port is colder than the average water column temperature and the barrier effect is limited to the surface layer (the rest of the water column is homogenous in and out of port); very strong winds may 
therefore favour surface water outflow (dilution basin). In spring, when the barrier effect is absent and the surface layer is warmer, strong winds may favour vertical mixing due to probable cooling of the surface layer, thus leading to organism retention and ultimately sinking. In summer, the stratified water column (no barrier effect) probably remains stable in weak wind conditions, which most probably induce limited surface mixing and HAOP retention in the surface layer.

The port of Koper is moderately deep $(11-20 \mathrm{~m})$ and is open towards the sea. During the study it was of the dilution type, favouring HAOP spread. The prevailing easterly winds blow the water out to the open sea. In autumn and winter, the water column was mixed or stratified due to a colder surface layer (barrier effect). The weak autumn and moderate winter winds probably induce surface water and HAOP outflow, whereas in spring and summer the water column is stratified due to a warmer surface layer (barrier effect). Weak easterly winds may favour slow surface spread, or they may be so weak as to induce mere surface mixing (HAOP retention).

The port of Trieste is moderately deep (14-19 m) and is located in an open bay partially enclosed by breakwaters. Since the prevailing winds are easterly and of low intensity, the water moves most likely towards the open sea. In autumn and winter there seems to be no barrier effect. In autumn, a stratified water column and a probable dilution basin favour water, and probably HAOP outflow towards the open sea, enhanced by weak winds. In winter, the mixed water column and the concentration basin suggest HAOP sinking, the low wind probably contributing to this effect. In spring, the water column was stratified and a barrier seemed to form in the surface layer; the concentration basin involves sinking, and weak winds likely confine the water with HAOP in port. In summer, the water column was stratified; the dilution basin favours outflow (no barrier effect), and weak winds probably favour HAOP outflow from the port.

The port of Venice is located in a wide lagoon; it is characterized by shallow to moderate depth (5-12 m) and is naturally separated from the open sea. A continuous barrier effect and weak easterly winds favour water inflow into the port and generally the lagoon, whereas the basin is of the dilution type, favouring outflow. The likeliest scenario involves both surface outflow and water retention in the port, with HAOP sinking; both processes are of low intensity.

In the port of Ancona, which is characterized by moderate depth $(5-10 \mathrm{~m})$ and is enclosed by breakwaters, the connection with the open sea is in the north-western area and is fairly narrow. The water column was generally mixed. In autumn the basin was of the dilution type, i.e. it
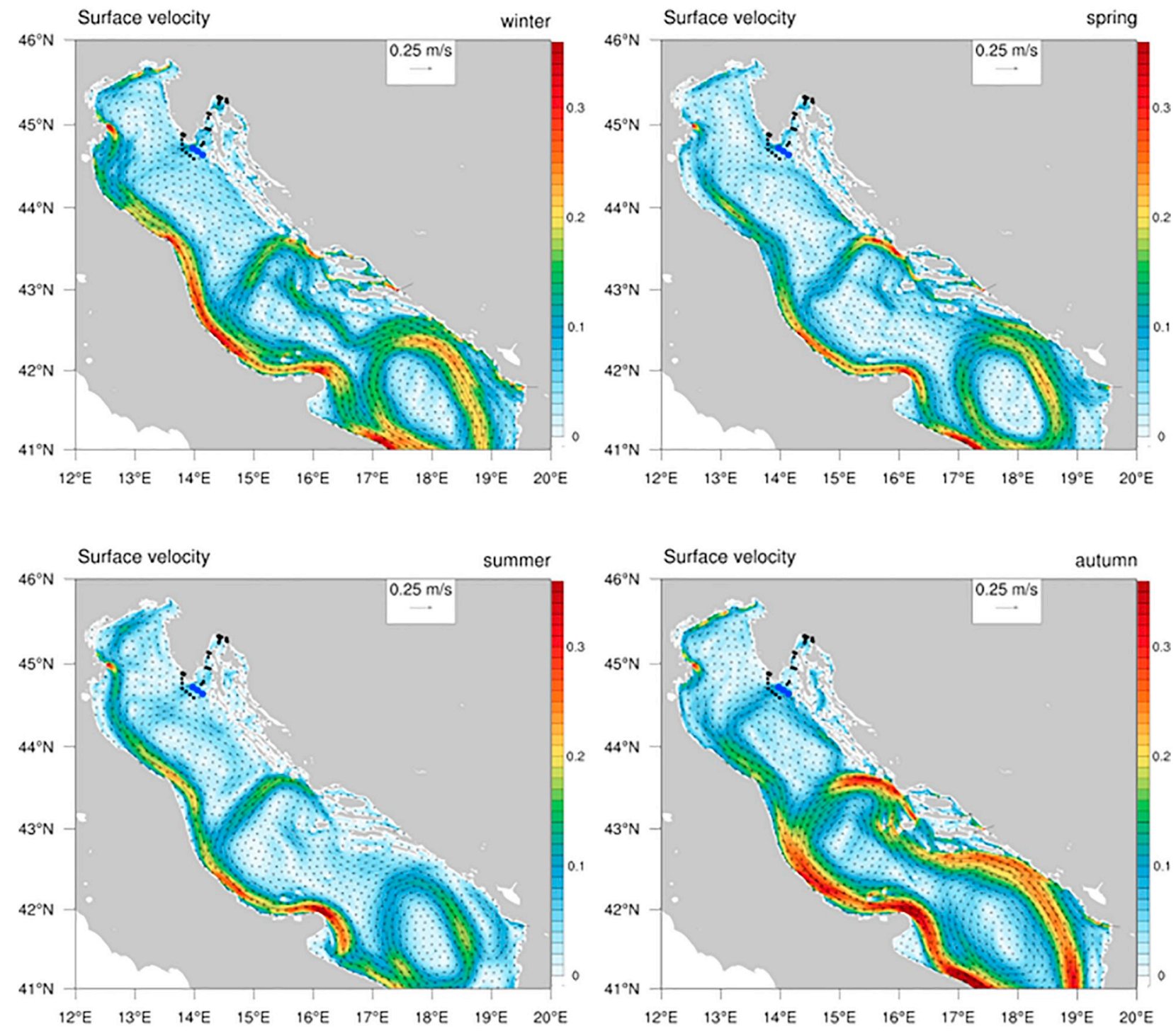

Fig. 2. Adriatic surface circulation (current, $\mathrm{m} / \mathrm{s}$ ) in winter (top left), spring (top right), summer (bottom left), and autumn (bottom right). Blue dots: Acoustic Doppler Current Profiler (ADCP) sampling sites; black dots: Conductivity-Temperature-Depth probe (CTD) sampling sites. (For interpretation of the references to color in this figure legend, the reader is referred to the web version of this article.) 
favoured HAOP outflow (no barrier effect); in contrast, the action of strong northerly winds probably induced vertical mixing and HAOP retention and sinking in port. In winter, a barrier effect was present throughout the water column; very strong northerly winds likely determined even more intense vertical mixing (and HAOP retention). In spring, the barrier effect was present throughout the water column; on one occasion the basin was found to be of the concentration type and on another day to be of the dilution type, which favour sinking and outflow, respectively. Strong westerly winds are likely to favour water inflow, resulting in HAOP retention and possible sinking during intense vertical mixing events. In summer, the basin was of the concentration type, favouring sinking, and the barrier effect was present throughout the water column. Moderate northerly winds probably induce

Surface velocity
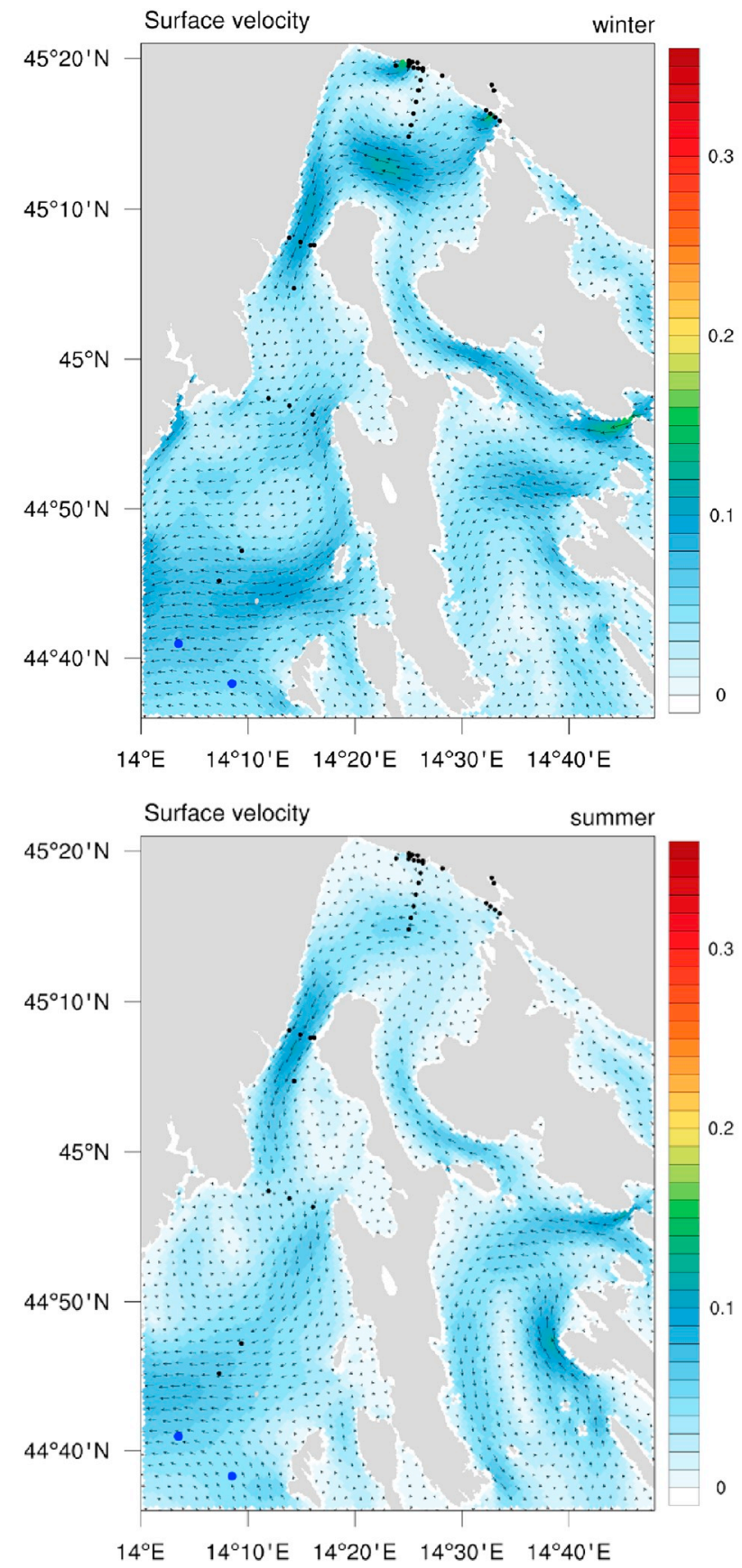

downwelling, which results in HAOP retention and sinking, in the southern area of the port.

The port of Bari is shallow to moderately deep (4-12 m) and is enclosed by breakwaters; the connection with the open sea is in the northern area and is fairly narrow. The water column was well mixed in autumn, winter, and spring (data for summer are not available). In addition, the basin was of the concentration type (favouring sinking) in autumn, winter, and spring, although a situation of dilution basin (favouring surface spread) was detected in spring. The mostly strong and northerly winds likely induce inflow of surface water and HAOP retention and sinking along potential downwelling areas on the southern side of the port. In winter, the most likely process in presence of very intense winds is vertical mixing (involving HAOP retention and
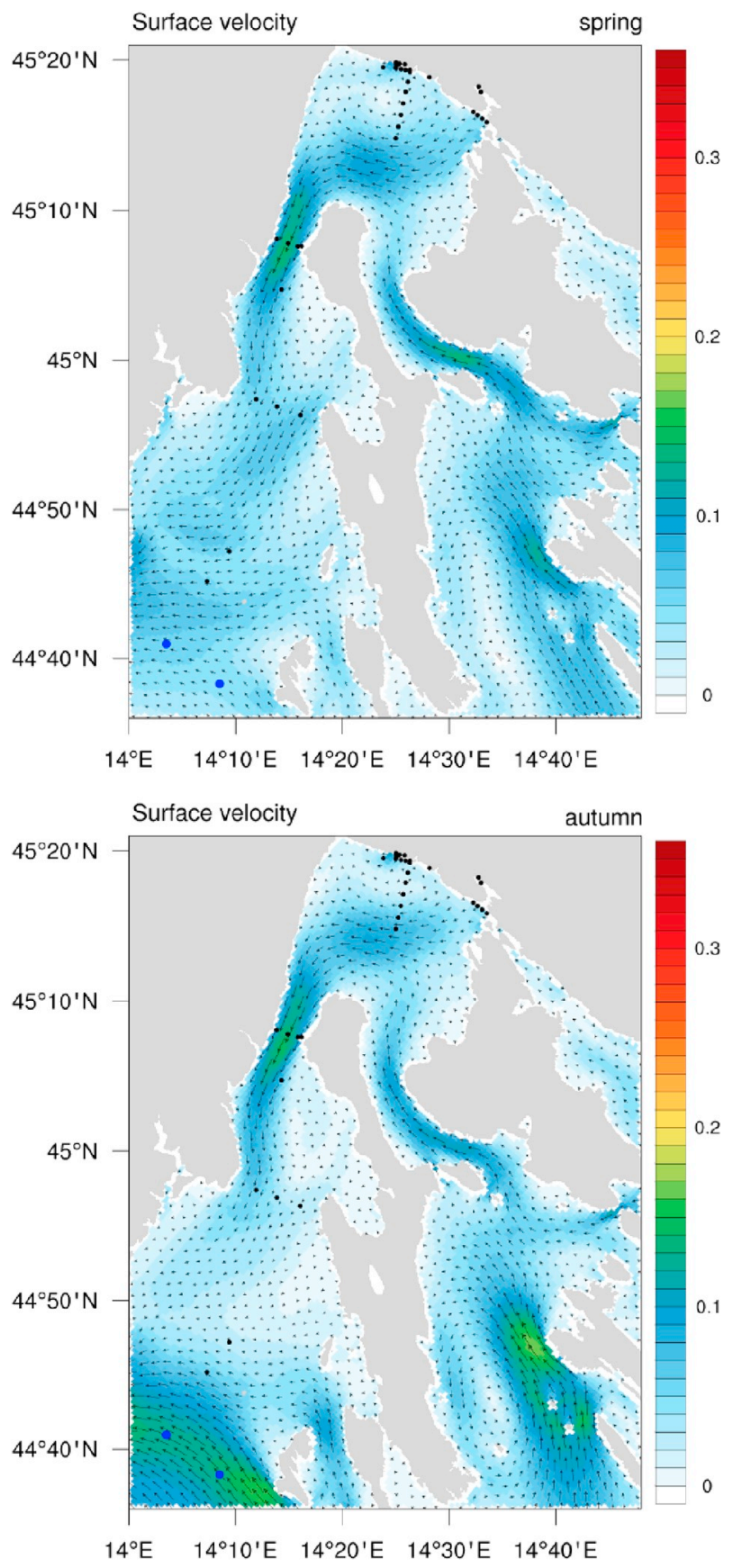

Fig. 3. Surface currents in Kvarner and Rijeka Bay in winter (top left), spring (top right), summer (bottom left), and autumn (bottom right). Blue dots: Acoustic Doppler Current Profiler (ADCP) sampling sites; black dots: Conductivity-Temperature-Depth probe (CTD) sampling sites. (For interpretation of the references to color in this figure legend, the reader is referred to the web version of this article.) 
sinking), despite the barrier effect, which is limited to the surface layer. The situation is probably similar in summer, for which the only available information was the presence of strong winds. In autumn and spring, the port is characterized by strong northerly and southerly winds. The barrier effect is present in spring and absent in autumn. Northerly winds probably result in HAOP sinking and retention, whereas southerly winds may blow surface water and HAOP out to sea, especially in autumn (no barrier effect). In spring, the barrier effect is present throughout the water column; southerly winds may induce vertical mixing and HAOP retention and sinking in the port, especially when the basin is of the concentration type.

Occasional and sometimes very strong winds probably induce HAOP resuspension from sediment, particularly in conditions of mixed water column and in the shallower ports, i.e. Ancona, Bari, and Pula in spring and autumn and Ancona, Durrës, and Pula in winter. The same effect may occur in ports characterized by generally low to moderate winds, like Rijeka, and in moderately deep basins, such as Split and Šibenik during occasional episodes of very strong wind, like for instance the strong Bora event that was recorded in February 2015 (Fig. 16).
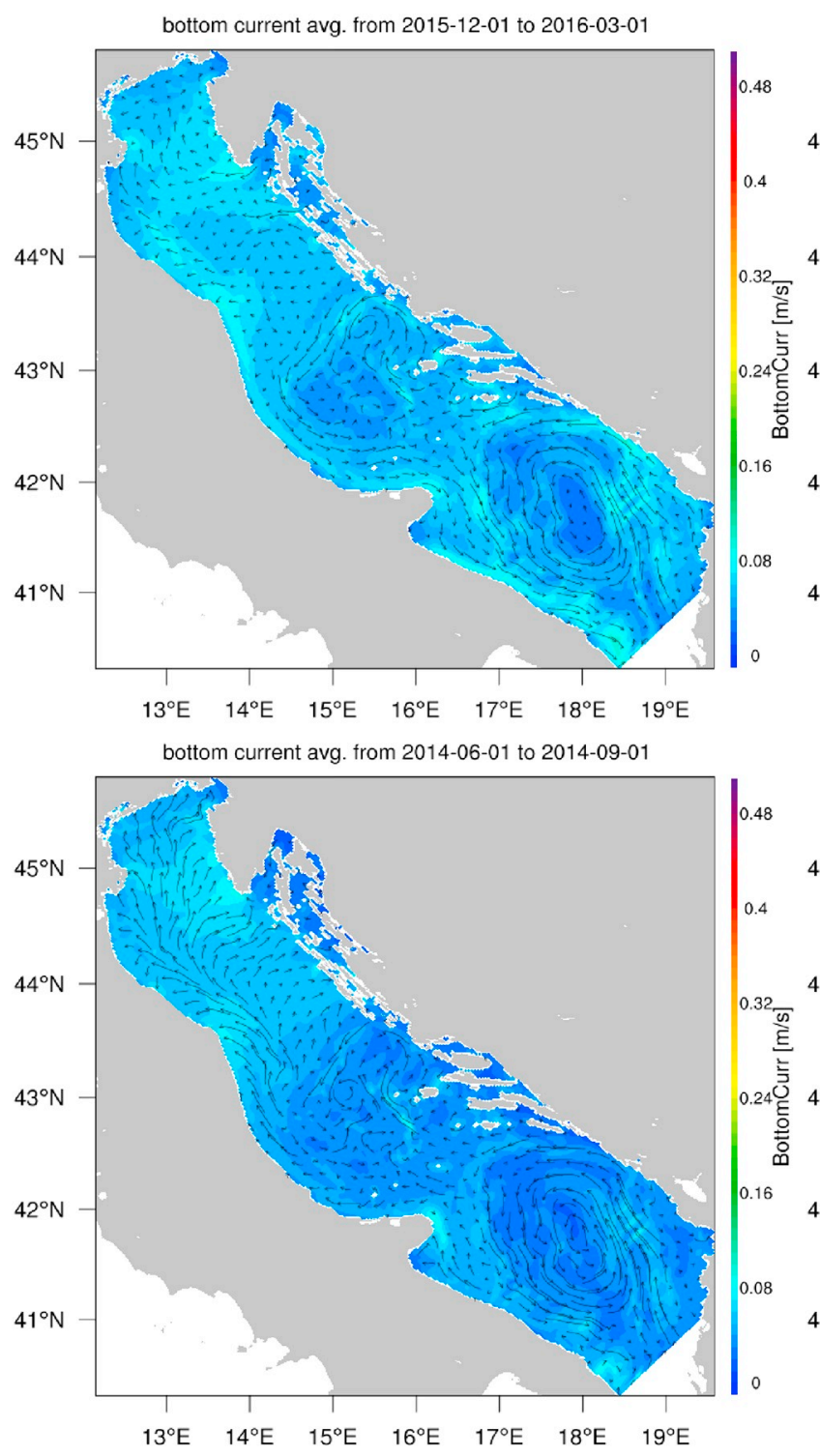

\subsection{Seasonal circulation dynamics}

\subsubsection{Winter circulation}

In winter, the Adriatic surface circulation shows a well-known cyclonic pattern (Fig. 2, top left) with two strong cyclonic gyres - a northern gyre around JP and a southern gyre around the SAP - while the Eastern Adriatic Current (EAC) flows along the Croatian coast. The EAC carries warmer and saltier water from the southern Adriatic to the cooler north-eastern Adriatic, weakening as it approaches the northern Adriatic and Istria. On the western side of the Adriatic, the WAC flows close to the coast due to the presence of areas characterized by homogeneous water density, with freshwater inputs from the River Po, and flows towards the Otranto strait and out of the Adriatic. The transverse westward water moving from the KRB entrance (Fig. 1) reaches the western side, where it becomes part of a large cyclonic gyre that includes the WAC, approximatively south of $44.7^{\circ} \mathrm{N}$. In the northernmost part of the Adriatic, another surface cyclonic gyre, which eventually becomes part of the WAC, induces intense water movements along the coast, starting from the Gulf of Trieste.

The nested model provides a greater resolution for the intensely

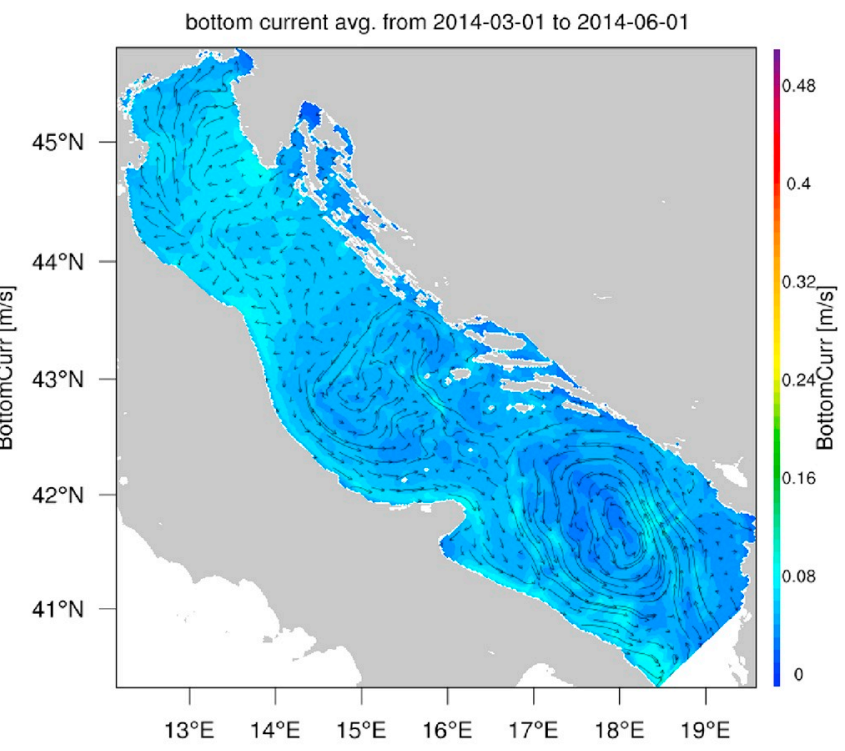

bottom current avg. from 2014-09-01 to 2014-12-01

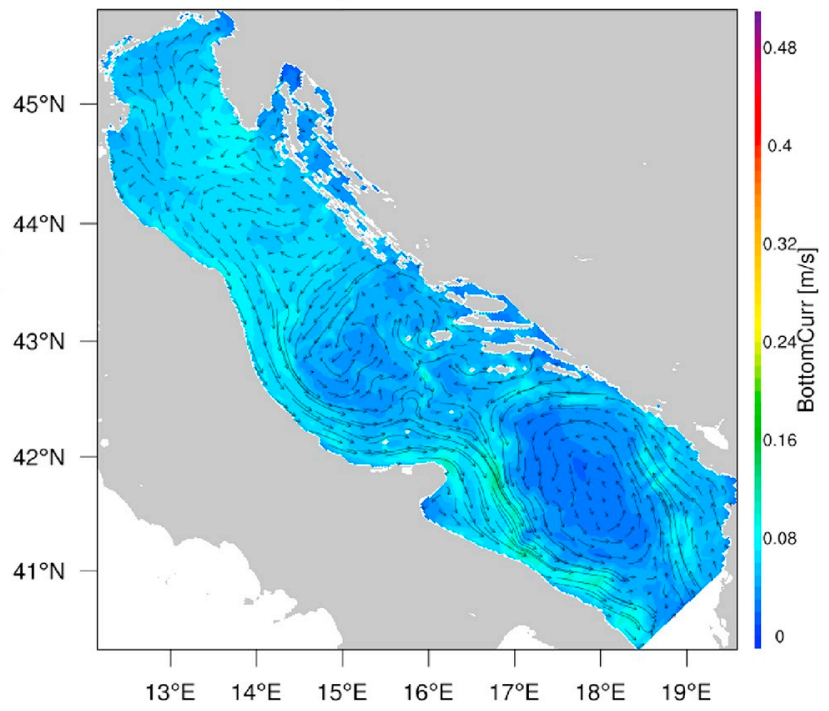

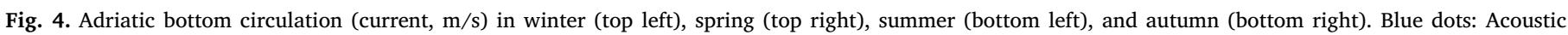

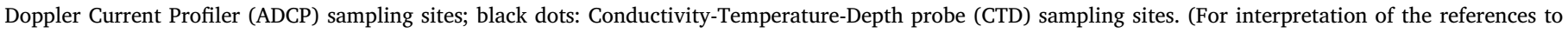
color in this figure legend, the reader is referred to the web version of this article.) 
investigated KRB area (Fig. 1), which exhibits a complex dynamics (Fig. 3, top left). Cyclonic patterns form due to wind shear, because high mountains and narrow passages modify wind flows. Currents are slowest in the central region of Rijeka Bay and stronger in the narrow straits. Based on the modelling results, Rijeka Bay is characterized by inflowing surface water between Krk and Cres islands (Fig. 3, top left) and by an outflowing current between the eastern Istrian coast and Cres Island.

Along the western Istrian coast (not shown), surface currents are generally weak and parallel to the coast, with a more intense flow in the northern area due to the influence of the River Mirna. On the southern tip of Istria, an outflow from KRB was also captured by the ADCP.

The bottom currents south of Palagruža Sill (around $43.5^{\circ} \mathrm{N}$ ) were similar to the surface currents but, interestingly, those north of $43.5^{\circ} \mathrm{N}$ were quite different from those on the surface (Fig. 4, top left). In fact, unlike the intense surface WAC flowing down the western Adriatic coast towards Otranto, they mostly flowed in NW direction, together with water from KRB that was also diverted northward. The bottom currents seemed to be weakest in winter, especially in the northern area.

During the December 2014 cruise, surface temperature ranged from $13^{\circ} \mathrm{C}$ in the Velebit Channel to $17-18^{\circ} \mathrm{C}$ at the KRB entrance (Suppl. Fig. 1, top left). Comparison with satellite sea surface temperature (Suppl. Fig. 1, top right) demonstrated that the model data were accurate.

\subsubsection{Spring circulation}

In spring, the Adriatic surface circulation was similar to the winter circulation (Fig. 2, top right). Currents were slightly weaker in the southern and middle Adriatic and more intense along the western coast of Istria (not shown). Water from KRB (Fig. 2, top right) flowed on the surface in western direction, as in winter. Coastal water movements among the Gulf of Trieste, the River Po delta, and the WAC were less intense than in winter. The formation of a large anticyclonic gyre west of the Po delta was accompanied by intensification of water movements in NE direction close to the Istrian coast (Istrian Coastal Countercurrent, ICCC). The distribution of geostrophic currents and density distribution analysis (not shown) pointed to a large anticyclone around the lower density pool at the KRB entrance.

In KRB (Fig. 3, top right), surface currents were similar to those of winter, albeit without the narrow, pronounced jets due to the strong winter Bora winds. Before the intense summer heat, CTD sampling showed that surface temperature in the bay was still homogeneous. Comparison with satellite data yielded similar values and showed a small anticyclonic gyre (Suppl. Fig. 1, bottom).

The bottom circulation (Fig. 4, top right) was similar to the surface circulation except in the western area (north of $44^{\circ} \mathrm{N}$ ), which is characterized by strong NW movements. The anticyclonic gyre off the Po delta seemed to extend from surface to bottom. The bottom circulation intensified during spring.

\subsubsection{Summer circulation}

In the summer of 2015, the surface currents (Fig. 2, bottom left) were less strong than in winter and spring. The WAC was not flowing close to the western coast, since the River Po freshwater spread through the North Adriatic; here, the eastern portion of a cyclonic gyre, detected north of the River Po delta, contributed to the coastal circulation along the western Istrian coast. Interestingly, a counter current flowing close to the coast of Istria was detected above Lim Bay as part of the small anticyclonic eddy, and could be seen even in the summer 3 monthaveraged field (not shown).

A large anticyclonic gyre detected in the open sea, southwest of the tip of Istria, carried water from the KRB southwards (not shown). The circulation in the northernmost area was not discernible, except for the ICCC, which was very pronounced and extended from the Gulf of Trieste in southward direction. The gyres typical of the northernmost part of the Adriatic, the cyclonic gyre north of the River Po delta, and an anticyclone in the open sea west of Rovinj and Pula were not detectable. An anticyclonic gyre encompassing the entire area may form north of $43-44^{\circ} \mathrm{N}$ both in the surface and the bottom layer. Water movements in NW direction were especially marked in the western part of the area north of $43-44^{\circ} \mathrm{N}$, whereas at the same latitude SW movements were predominant on the eastern side. The large anticyclonic gyre around the lower density pool at the KRB entrance was observed, as in spring, both in geostrophic fields and in the summer model (not shown).

In KRB (Fig. 3, bottom left) the surface currents showed the same direction as in winter and spring, although in summer they were weakest, with an average speed $<10 \mathrm{~cm} \mathrm{~s}^{-1}$.

The bottom circulation (Fig. 4, bottom left) was generally similar to the surface circulation seen north of the central Adriatic cyclonic gyres. Interestingly, the bottom currents moved in northward direction, but in the vicinity of the western coast they moved in NW direction, whereas near the eastern coast they had a NE-E direction. The bottom circulation was most intense in summer.

\subsubsection{Autumn circulation}

After a relatively low-energy summer period, the autumn atmospheric forcing brings energy to the area, mostly through stronger winds, resulting in a stronger circulation (Fig. 2, bottom right). The WAC was most pronounced in autumn. The North Adriatic cyclonic gyre was still present, whereas the EAC turned towards the KRB entrance. Along the western Istrian coast, currents were weak in the southern part and stronger, northbound, in the northern area (not shown).

The currents flowing westward from the KRB entrance reached far on the other side of the Adriatic, where they split into northbound and southbound currents both on the surface and near the bottom. Some surface and near-bottom water from KRB flowed northwards along the Istrian tip. The gyre at the KRB entrance was not detected in the geostrophic currents fields.

In KRB (Fig. 3, bottom right) the currents became stronger, showing patterns similar to those of spring. In the narrow straits between the eastern Istrian coast and Cres Island, a strong outflow from KRB showed a speed up to $20 \mathrm{~cm} \mathrm{~s}^{-1}$.

The bottom layer circulation (Fig. 4, bottom right) was largely similar to the surface circulation except in the northernmost area, west of Istria, and in the Gulf of Trieste, where it showed a northern direction. In general, the circulation was moderately intense; the bottom WAC was strongest in autumn, similar to the situation seen on the surface.

The current velocity measured at the KRB entrance over four seasons reached values up to $74 \mathrm{~cm} \mathrm{~s}^{-1}$; this peak was recorded during a strong Bora wind event in the first half of February 2015, which involved the entire water column from the surface down to $-40 \mathrm{~m}$ and presumably reached the bottom (Fig. 16). The outflow along the transect was predominant during the whole period, with several episodes of stronger currents involving the entire water column.

\subsection{Tracer data}

The data regarding tracer spread on the surface layer by advection, supplied by the model, provided information on the intensity and the most probable direction of the spread of marine particles and species in 2014-2015, from the grid point closest to each port towards the open sea. These data indicate that the coastal areas in the vicinity of all 12 ports were likely to be affected by organisms released within the port or in nearby open sea areas (Figs. 5-15).

In the port of Durrës (Fig. 5), tracer spread was intense from January to May and showed a S-SW direction; in August and September it was sparser and showed a reduced intensity in S-SW direction and a high intensity in N-NW direction; and in November-January it was mainly in N-NW direction and generally showed the lowest intensity. 
In the port of Bar (Fig. 6), tracer spread was always in NW direction except in January-March and August-September, when it also showed a S-SW direction. It was most intense in January-March (both NW and $\mathrm{S}$-SW), less intense in NW direction in March-May, and weakest in August and September.

Since these two ports have no natural barriers towards the open sea, HAOP spreading from Durrës and Bar may join the general circulation.

In the port of Ploče (Fig. 7), tracer spread was sparse in NW-W-SW direction in August-September, it was more intense in March-May and November-January, and peaked in January-March, especially in NW direction. Due to the configuration of the coast and nearby islands, water spreading from the port is likely to remain confined in the area.

Spread from the port of Split (Fig. 8) was usually intense and in S-
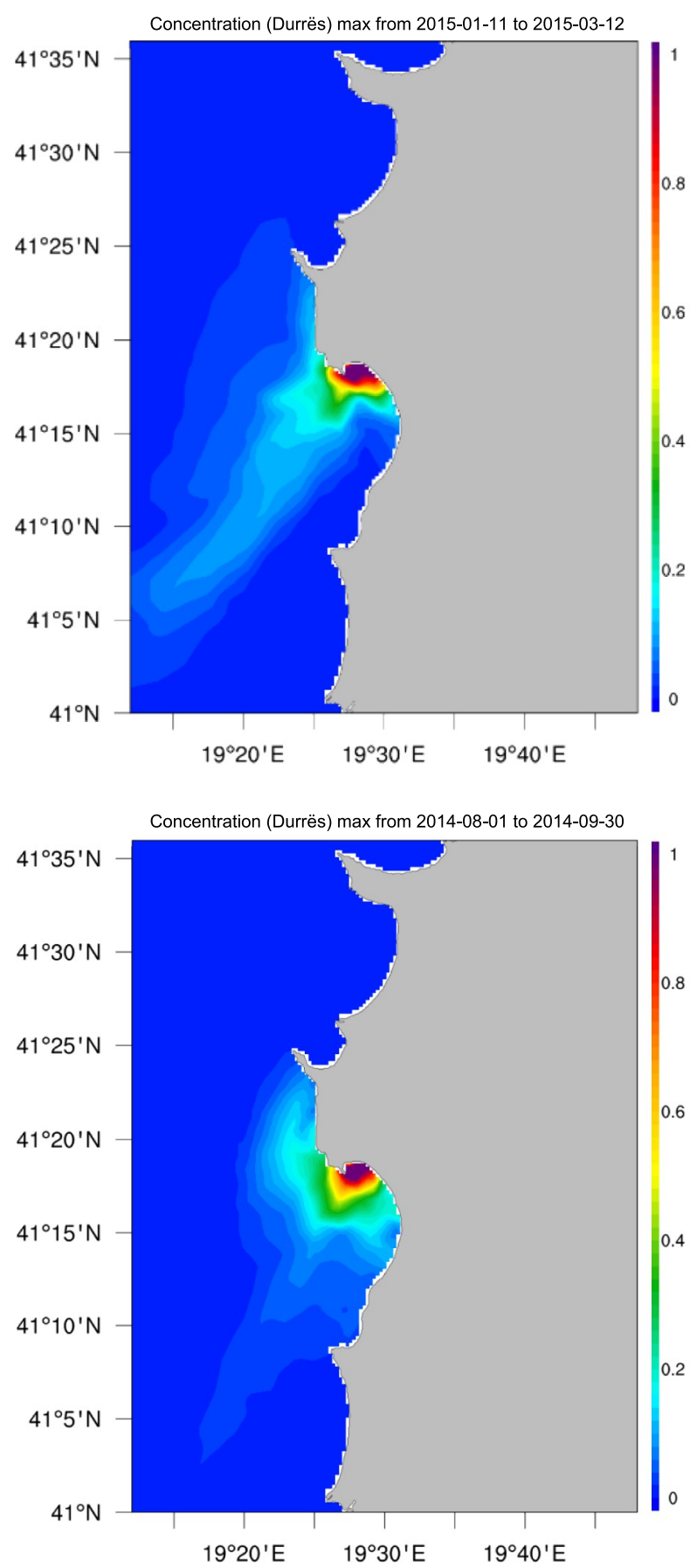

SW direction. In January-March and, especially, March-May and August-September, it was westward along the coast; in summer it was also detected over a wider area enclosed by islands, towards the open coast.

In the port of Rijeka (Fig. 9), tracer spread from November to May in two directions: NW along the coastline (decreasing in intensity) and SW (peak intensity in January-March, when it reached the KRB islands, which limited further spread). In August-September, moderately intense spread was seen only in SW direction. These data indicate that organisms can leave the bay, except in March-May.

Tracer spread from the port of Pula (Fig. 10) from November to March was intense in SW and W direction, towards the open sea. In March-May it was especially weak and limited, whereas in August-September it intensified and involved a wider area, especially
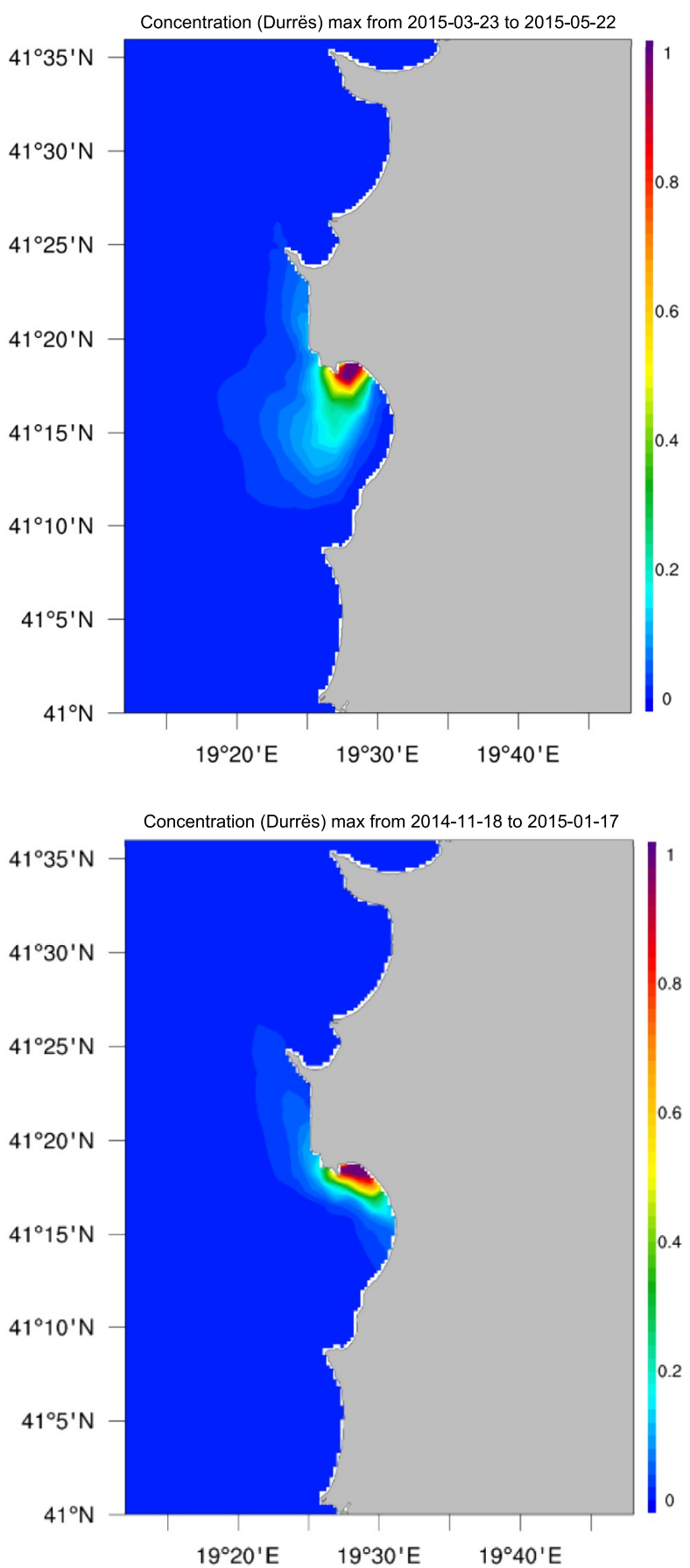

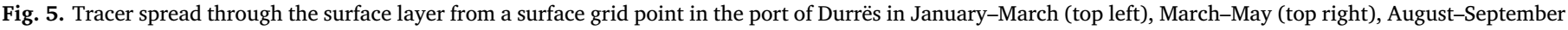
(bottom left), and November-January (bottom right). 

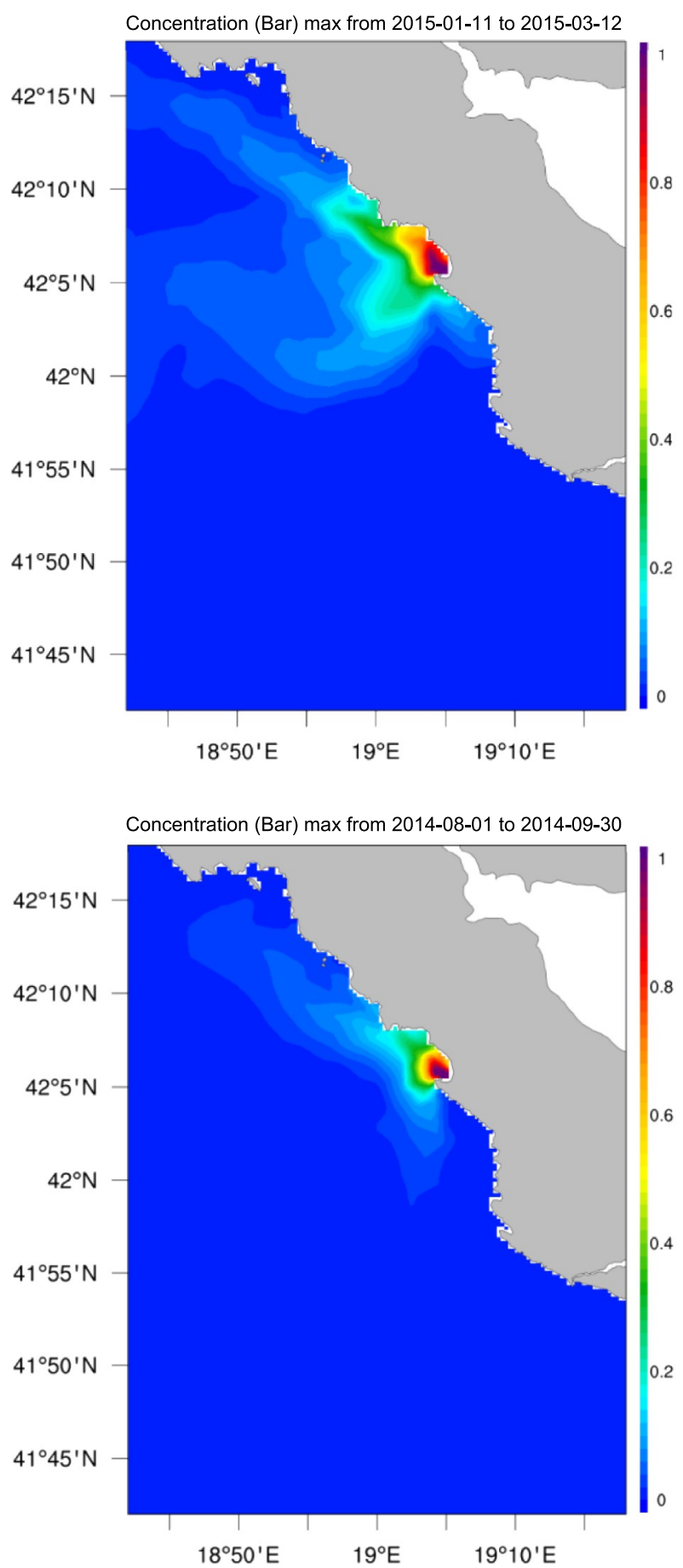

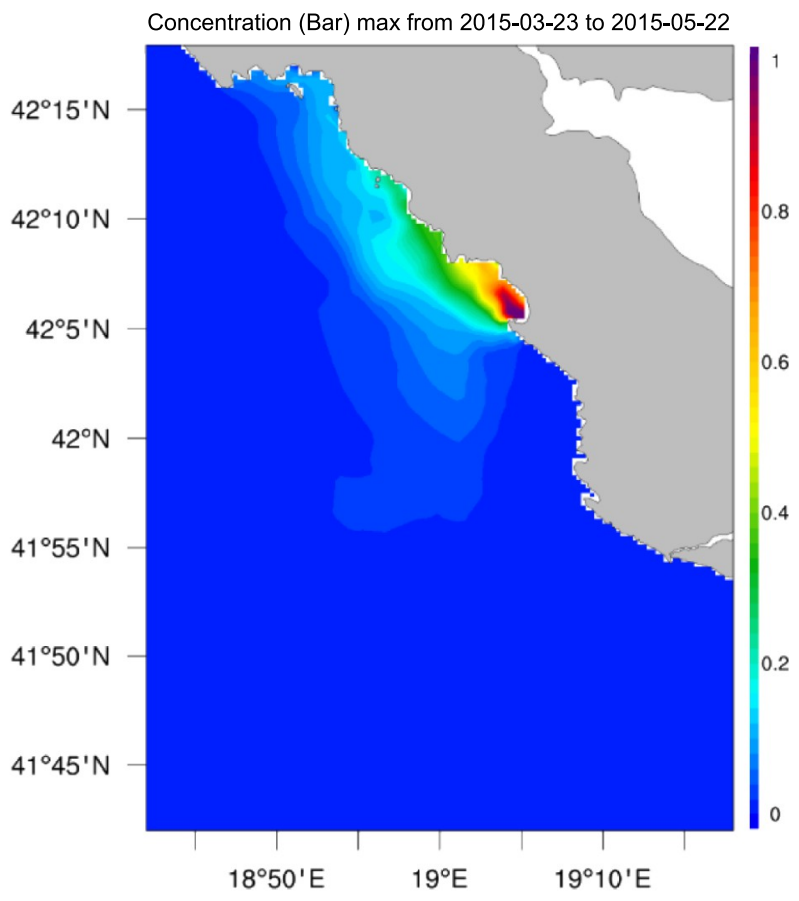

Concentration (Bar) max from 2014-11-18 to 2015-01-17

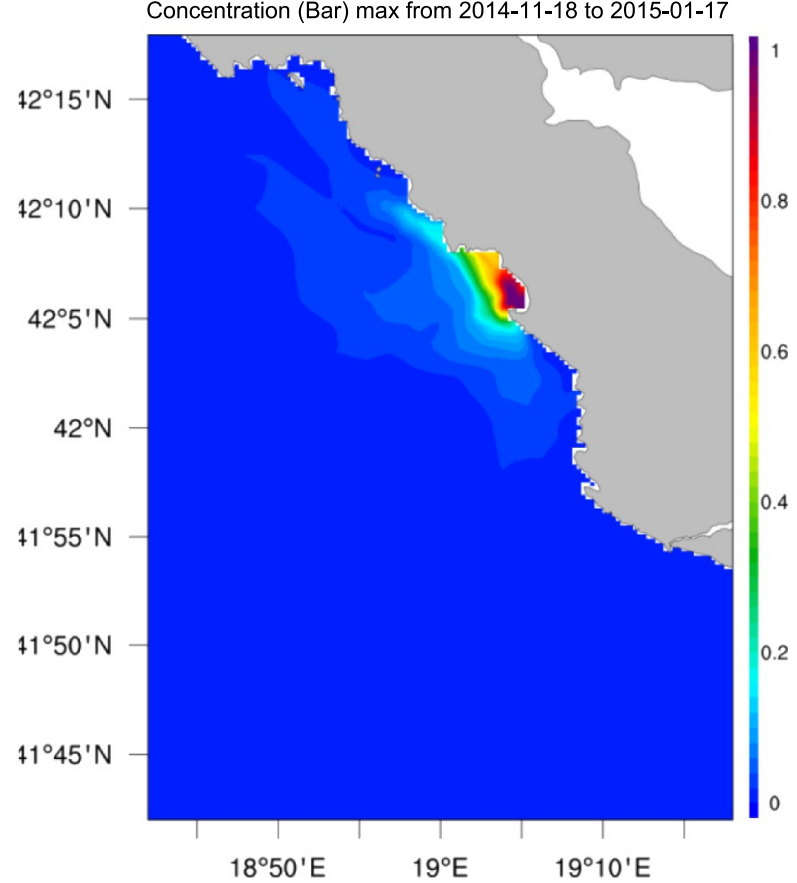

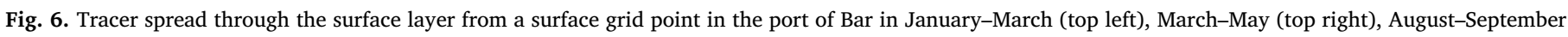
(bottom left), and November-January (bottom right).

southwards along the coastline towards the open sea.

Due to the location of the port of Koper (Fig. 11), tracer spread was always in NW direction, towards the open waters of the Gulf of Trieste; its intensity increased from March-May, when it was lowest, to August-September and November-January, peaking in January-March, when the tracer may have reached the open waters of the Gulf of Trieste.

Similarly, the location of the port of Trieste (Fig. 12) involved that the tracer also spread towards the open waters of the Gulf of Trieste. In November-May it was directed along the coast in NW and SW direction, whereas in January-March and August-September the tracer spread westwards, directly into the open waters of the Gulf, although with less intensity. The intensity trough was in March-May, the only period when spread failed to reach the open waters of the Gulf.

Since the connection of the port of Venice (Fig. 13) with the open sea is limited to three narrow inlets, the tracer can spread outwards only if it is highly intense and follows an eastern direction. Spread was intense in November-January (localized to one inlet), strongest in January-March (outflow through all inlets), and lowest in March-May and August-September. Patterns inside the lagoon were similar.

The ports of Ancona and Bari lie on the coast and have no natural barriers separating them from the open sea. Tracer spread from Ancona 

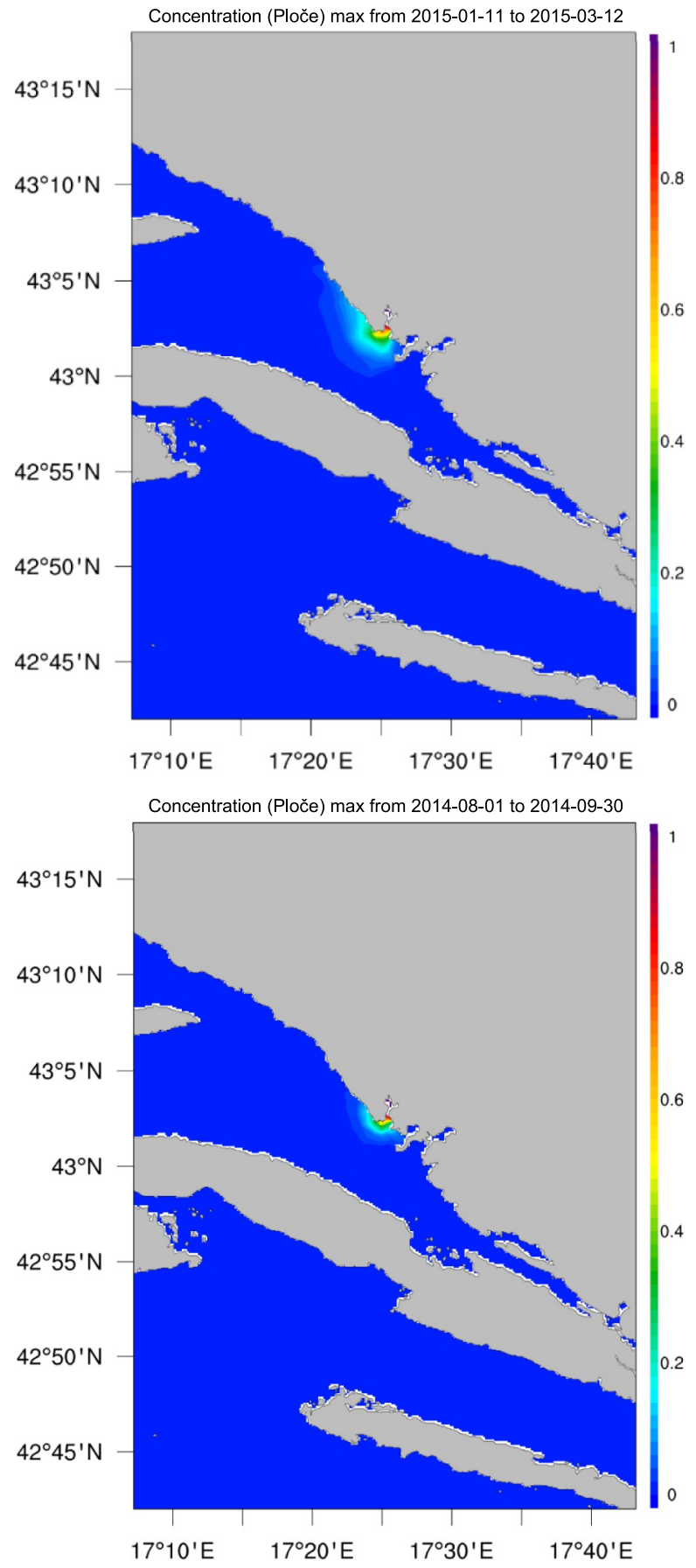
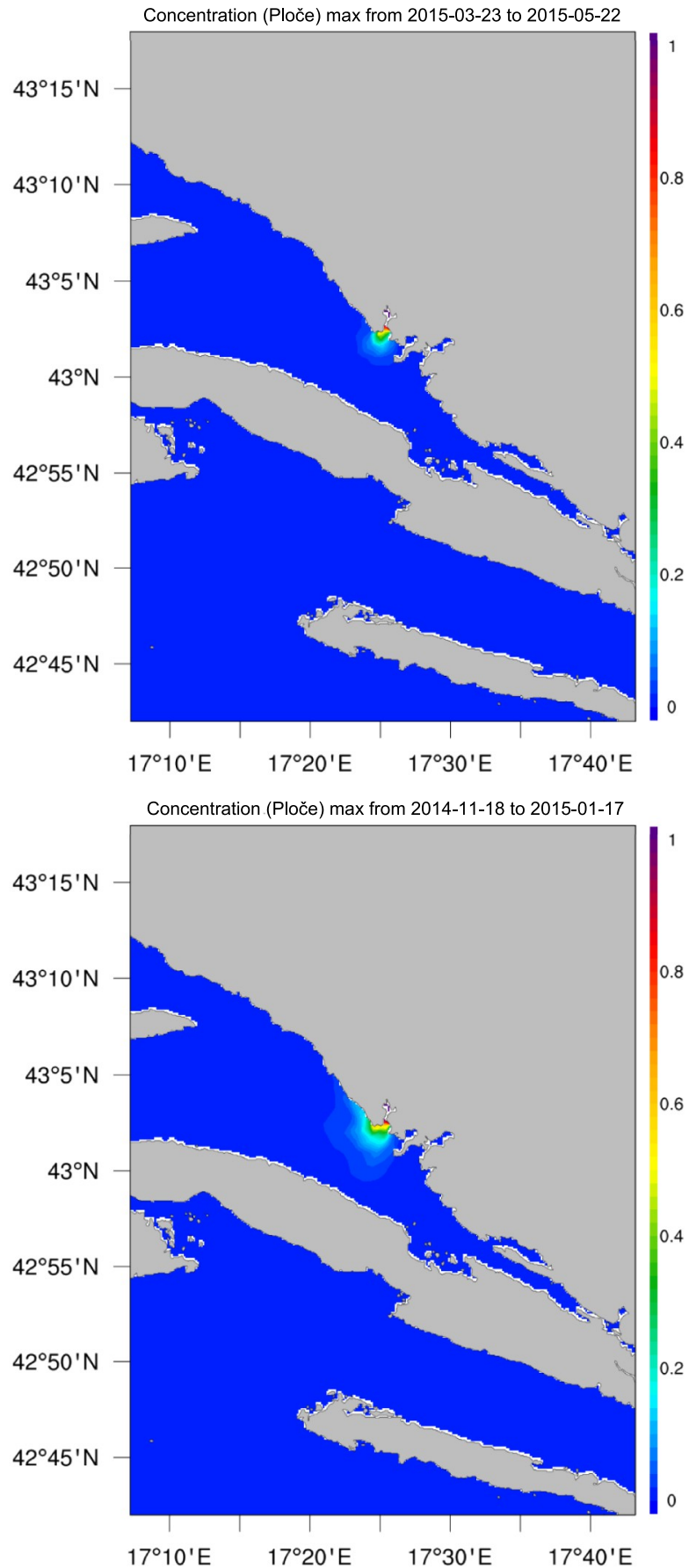

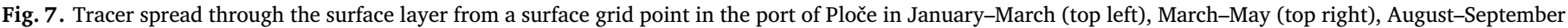
(bottom left) and November-January (bottom right).

(Fig. 14) was predominantly directed along the coast, both in N-NW and S-SE direction; it showed a predominant N-NW direction in November-January, when it was least intense, and in March-May and August-September, when it was more intense. Intensity peaked in January-March (both directions).

Tracer spread from the port of Bari (Fig. 15) was also only along the coast, both in N-NW and S-SE direction. It was most intense in January-March (SE direction) and less intense in March-May (main direction, NW), August-September, and November-January (main direction, SE).

\section{Discussion}

NIS are found in coastal waters everywhere in Europe. Some habitats, such as ports and lagoons, act as 'hubs' for their introduction, and some areas have a larger NIS array than others (Paavola et al., 2005; Lotze et al., 2006; Zaiko et al., 2011). Therefore, monitoring port water abiotic parameters is an important part of the study of seawater exchanges between port and open sea and is essential for a greater understanding of the natural dispersal of HAOP. However, the main factors affecting natural dispersal from the sites of release are currents and circulation patterns.

The study of natural HAOP dispersal from the 12 ports assessed in this investigation highlighted differences between surface and bottom 


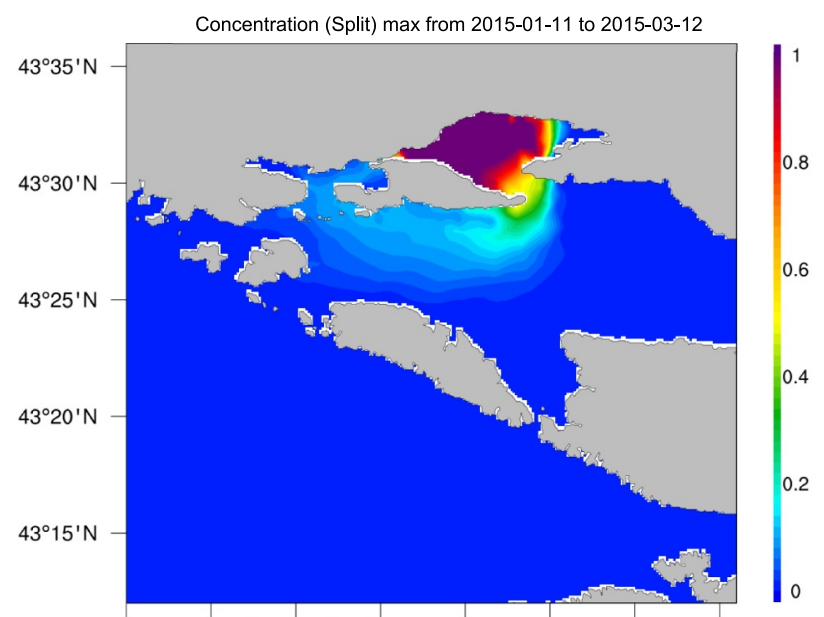

$16^{\circ} \mathrm{E} \quad 16^{\circ} 5^{\prime} \mathrm{E} 16^{\circ} 10^{\prime} \mathrm{E} 16^{\circ} 15^{\prime} \mathrm{E} 16^{\circ} 20^{\prime} \mathrm{E} 16^{\circ} 25^{\prime} \mathrm{E} 16^{\circ} 30^{\prime} \mathrm{E} 16^{\circ} 35^{\prime} \mathrm{E}$

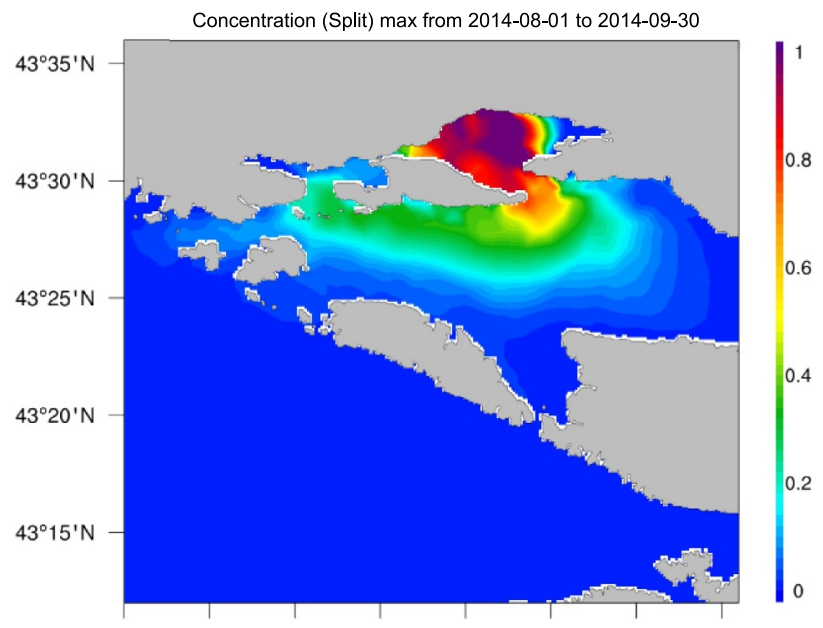

$16^{\circ} \mathrm{E} \quad 16^{\circ} 5^{\prime} \mathrm{E} 16^{\circ} 10^{\prime} \mathrm{E} 16^{\circ} 15^{\prime} \mathrm{E} 16^{\circ} 20^{\prime} \mathrm{E} 16^{\circ} 25^{\prime} \mathrm{E} 16^{\circ} 30^{\prime} \mathrm{E} 16^{\circ} 35^{\prime} \mathrm{E}$

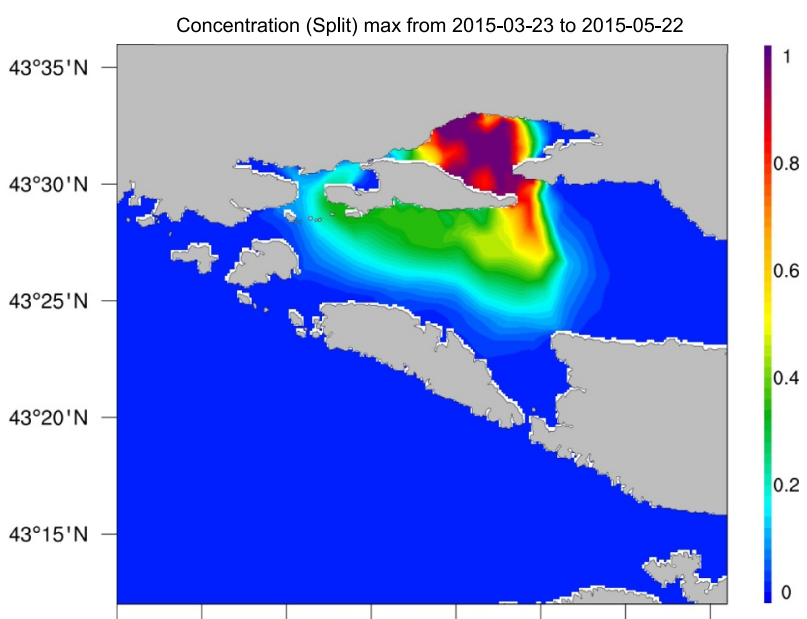

$16^{\circ} \mathrm{E} \quad 16^{\circ} 5^{\prime} \mathrm{E} 16^{\circ} 10^{\prime} \mathrm{E} 16^{\circ} 15^{\prime} \mathrm{E} 16^{\circ} 20^{\prime} \mathrm{E} 16^{\circ} 25^{\prime} \mathrm{E} 16^{\circ} 30^{\prime} \mathrm{E} 16^{\circ} 35^{\prime} \mathrm{E}$

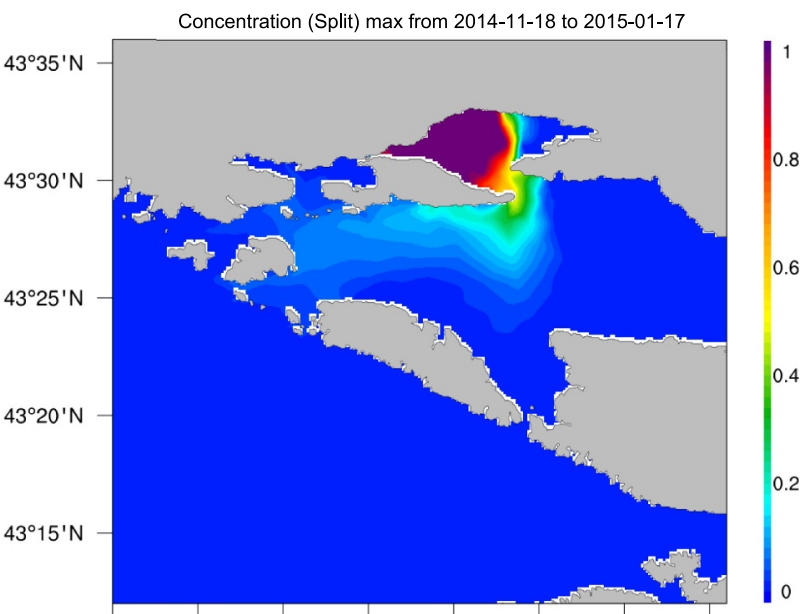

$16^{\circ} \mathrm{E} \quad 16^{\circ} 5^{\prime} \mathrm{E} 16^{\circ} 10^{\prime} \mathrm{E} 16^{\circ} 15^{\prime} \mathrm{E} 16^{\circ} 20^{\prime} \mathrm{E} 16^{\circ} 25^{\prime} \mathrm{E} 16^{\circ} 30^{\prime} \mathrm{E} 16^{\circ} 35^{\prime} \mathrm{E}$

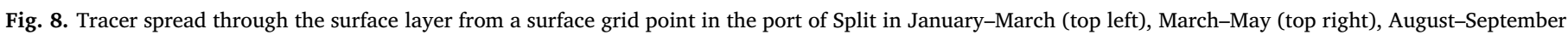
(bottom left), and November-January (bottom right).

as well as among seasons. Retention seems more likely in winter, spring and summer, whereas in autumn both retention and outflow seem to be equally probable. According to the present data, the HAOP released in the ports of Ancona, Bari, Durrës, Ploče, Split and Šibenik are likely to have remained largely confined to the basin, ultimately sinking to the bottom. The conclusions drawn for the port of Bari are in line with those of studies reporting that the local circulation pattern seems to be separate from the open sea circulation, indicating very limited exchange between the port and the open sea (Ben Meftah et al., 2011). The ports where retention is least likely seem to be Bar and Koper. In the ports of Pula, Rijeka, and Trieste, outflow of surface water appears to take place in two seasons, whereas HAOP retention seems to be likelier in the remaining months. The scenario hypothesized for the port of Venice was the least clear, since spread and retention seemed to be equally likely. Indeed, in the Venetian lagoon dispersal has been detected both within and outwards (Ferrarin et al., 2010). According to this study, Moreover, the present findings suggest that HAOP dispersal by diffusion, especially during tides, should be also considered. Our data indicate that future work should evaluate surface and bottom circulation, grain size, circulation modelling in ports, and response to strong winds and tides, like earlier research conducted in the Venetian lagoon. The contribution of abiotic factors, i.e. differences in nutrient concentrations and nutrient limitations in port and adjacent open water, to the barrier effect is difficult to estimate and is therefore not included in the HAOP spread scenarios presented above.
Data analysis showed that the 12 ports were most often dilution basins, where surface water outflow is compensated for by near-bottom water inflow. Particles floating in the surface layer are therefore likely to be carried around and/or outside the port, whereas non-floating particles should sink and be retained, due to the inflow of bottom water. Organic and inorganic particles are thus expected to accumulate in the deeper water layers and at the bottom, also with a contribution from the winds. In particular, Bora winds are capable of inducing strong water inflow in the bottom layers of dilution ports in the eastern Adriatic. In Rijeka, dinoflagellate cysts have been collected first near the port and later inside it, possibly due to displacement by bottom currents. In contrast, in situations where ports act as concentration basins, floating particles are more likely to circulate inside the basin, while material found in the bottom layers flows out. The present data document this process, which was detected mostly in spring in Ancona (where it also occurred in summer), Bar, Bari (where it also took place in autumn and winter), and Trieste (also in winter), whereas in the port of Rijeka it was observed only in autumn. These findings stress the importance of sediment monitoring, where HAOP can accumulate and eventually spread to the open sea through the bottom layer.

Unlike the southern Adriatic area (south of JP), where the circulation seemed to show limited seasonal changes, the patterns in the northern Adriatic showed a clear dependence on season. However, the marked year-to-year variation documented in the northern Adriatic suggests that the patterns recorded in the present study may differ 


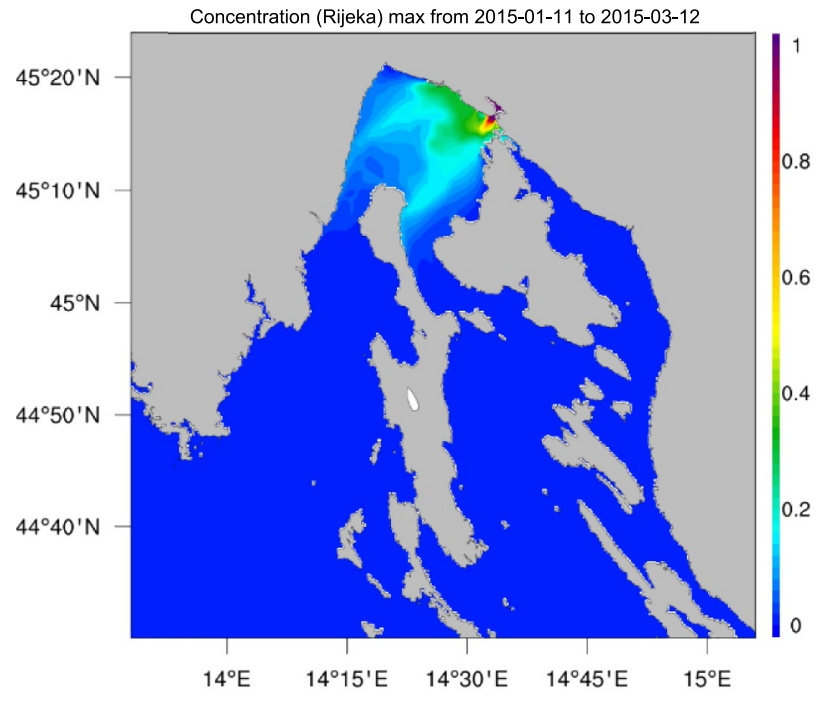

Concentration (Rijeka) max from 2014-08-01 to 2014-09-30

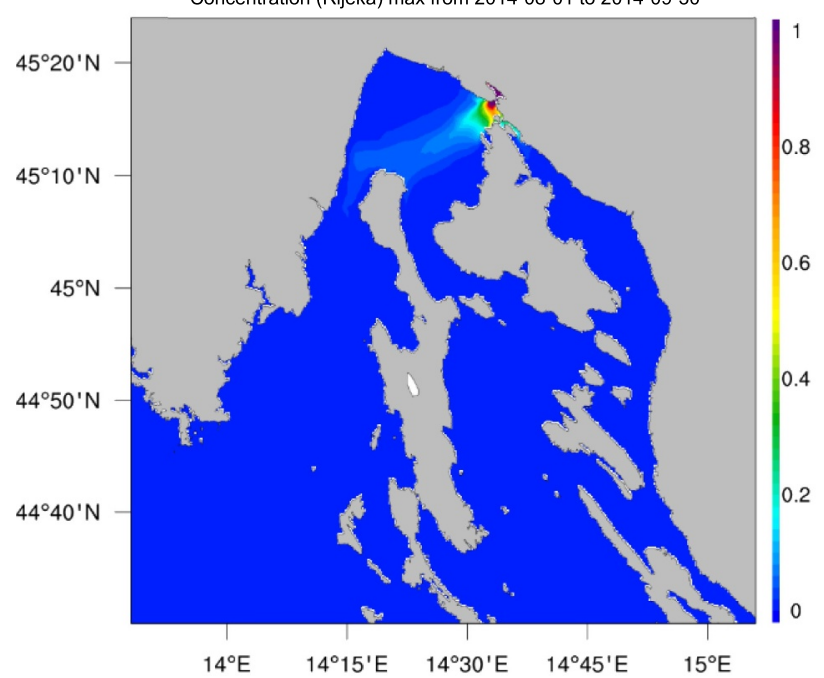

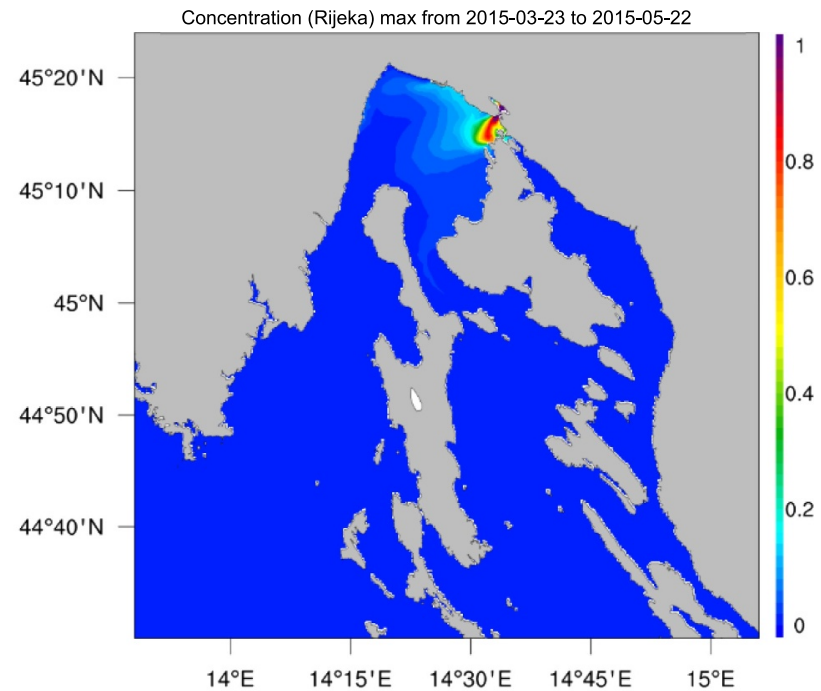

Concentration (Rijeka) max from 2014-11-18 to 2015-01-17

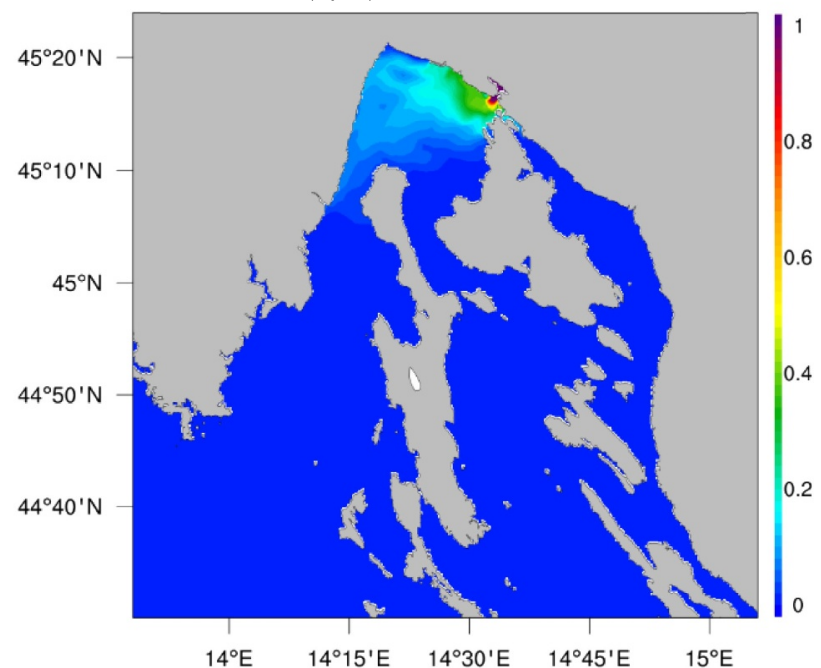

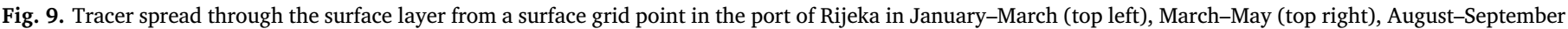
(bottom left), and November-January (bottom right).

significantly from those of other years (e.g. Supić et al., 2012).

During the study period, winter in the northern Adriatic began with a cyclonic surface circulation (which drew water westwards from KRB) and with intense coastal currents in the western area of the basin, beginning in the northernmost part (Gulf of Trieste; WAC), whereas in the deeper layers the currents moved mostly in NW direction.

In spring, a similar circulation pattern was characterized by the displacement of water masses from the KRB entrance in westward (surface) or northward (bottom) direction, weakening of the cyclonic currents and the WAC, and formation of anticyclonic currents, including the SE-bound ICCC, in the northernmost part of the region, off the Po delta. In spring, a large anticyclonic gyre formed for the first time at the KRB entrance (Suppl. Fig. 1, bottom).

In summer the large northern anticyclonic gyre, which encompassed the whole water column, involved the entire region north of JP, drawing water from KRB in SE direction. Although seasonal averaging prevented visualization of smaller gyres, a smaller anticyclonic gyre off Istria, a more northern cyclonic gyre in the north Adriatic basin, and an anticyclonic gyre at the KRB entrance were probably also present. Gyres of different extensions and durations in the north Adriatic basin and $\mathrm{KRB}$, which are typical of the warmer months, may provide a major contribution to HAOP dispersion, especially resting stages like dinoflagellate cysts, as noted in the stagnant areas of gyres, where species are more likely to reproduce and multiply. In autumn, the cyclonic circulation resumed, flowing from KRB in westward direction and near the western coast in NW and SE direction.

In anticyclonic gyres, downwelling may result in accumulation of cysts and other organisms in deeper and bottom layers, while the material found in cyclonic gyres (e.g. cysts, other organisms, pollutants) can be brought up to the surface from such layers.

The results of the present investigation suggest that HAOP released in port (with ballast water) may either be retained or flow out and potentially be caught up by the general Adriatic circulation. The following scenarios may be sketched. In winter, HAOP released in the northern Adriatic ports (Koper, Trieste, and Venice) would spread southwards along the western Adriatic coast, carried by the strong WAC; HAOP from the port of Trieste would be those least likely to spread, due to retention. The WAC would also be able to carry HAOP from the ports of Ancona and Bari (albeit their retention in port would be far more likely) right down to the SAP cyclonic gyre; the latter may facilitate a further eastward spread to the eastern coast, most probably skipping Albania and Montenegro - which are characterized by weak currents close to the coast - but reaching the south Croatian coast. Interestingly, HAOP released into the ports of Durrës (albeit retention may be likelier) and Bar might be carried northwards along the eastern coast, but also westwards and then down the southern Italian coast by 

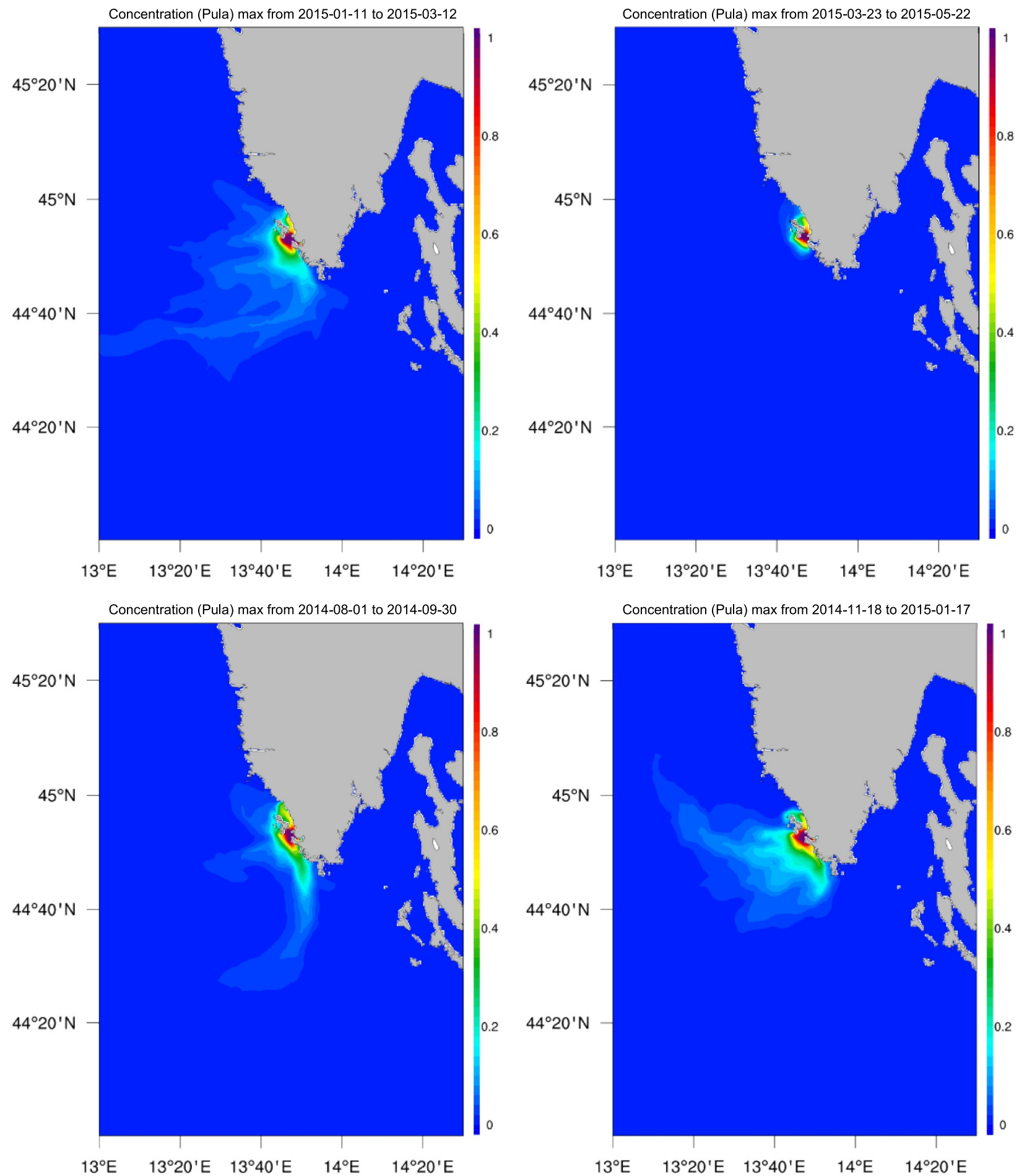

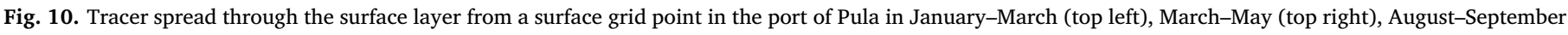
(bottom left), and November-January (bottom right).

the cyclonic gyre in the central area of the eastern coast (JP). HAOP from the ports of Ploče, Split, and Šibenik would also be able to be carried westwards to the central Italian coast by the same gyre, rather than spread northwards along the Croatian coast, because the northward EAC current is weaker. However, data analysis indicated that in the ports of Ploče and Split retention was more probable. From Pula and Rijeka (although in the latter retention seems more probable), a westward spread to the Italian coast would be much more likely, especially under intense Bora winds, than a northward spread along the Istrian coast and into the Gulf of Trieste. Here, the ports of Trieste and Koper would be more prone to influences from the eastern coast in winter than in spring, when they would be more susceptible to spread from the port of Venice (even though, as noted above, spread from this port is fairly improbable); in all the other situations the spring pattern would be similar to the one of winter, with variations related to retention/outflow in some ports. In spring, HAOP spread from the ports of Rijeka and Split seems more probable than retention, whereas retention seems likely in Bar, Koper, Pula, and Šibenik, and possibly also in Bari and Koper. The main difference in summer compared with winter and spring should regard the central Adriatic, where eastward spread, 


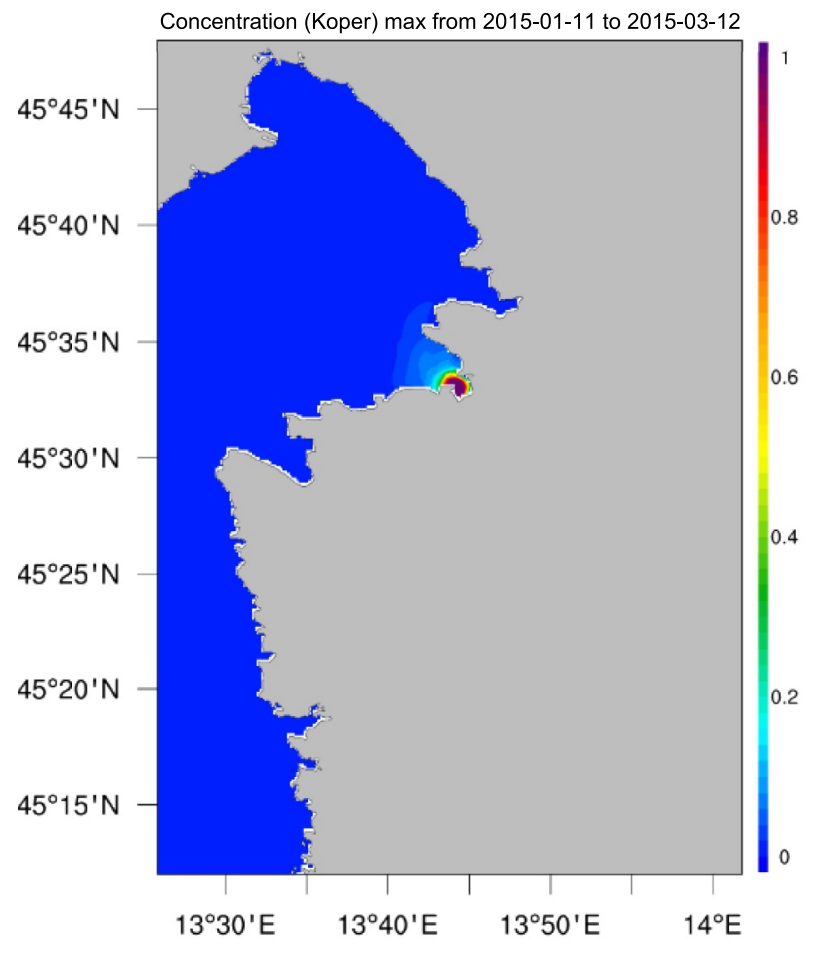

Concentration (Koper) max from 2014-08-01 to 2014-09-30

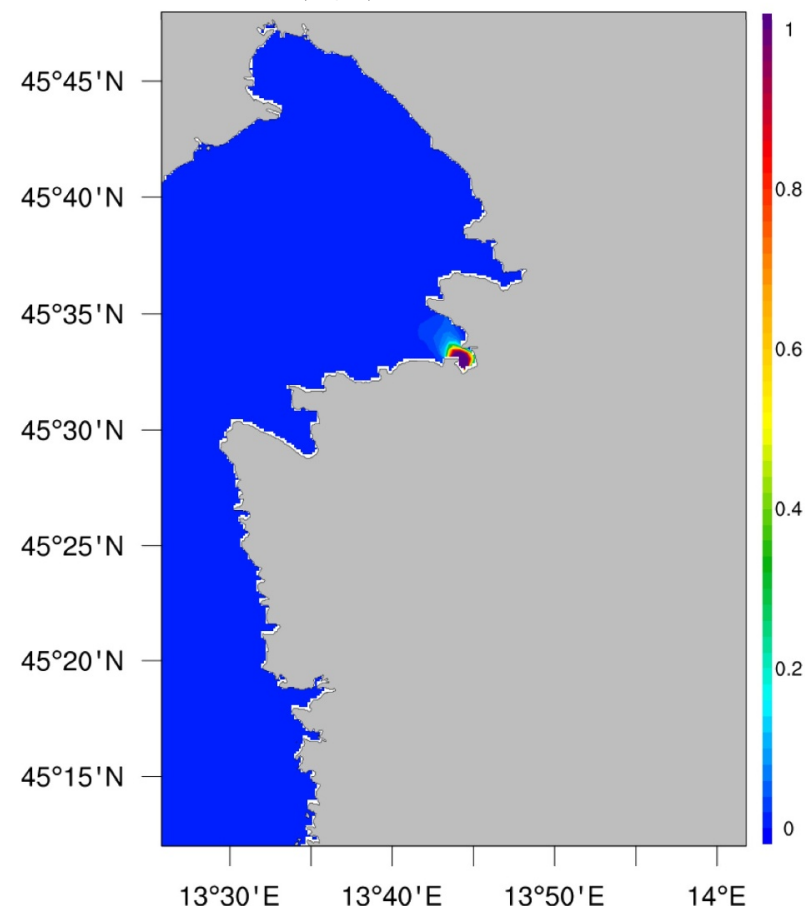

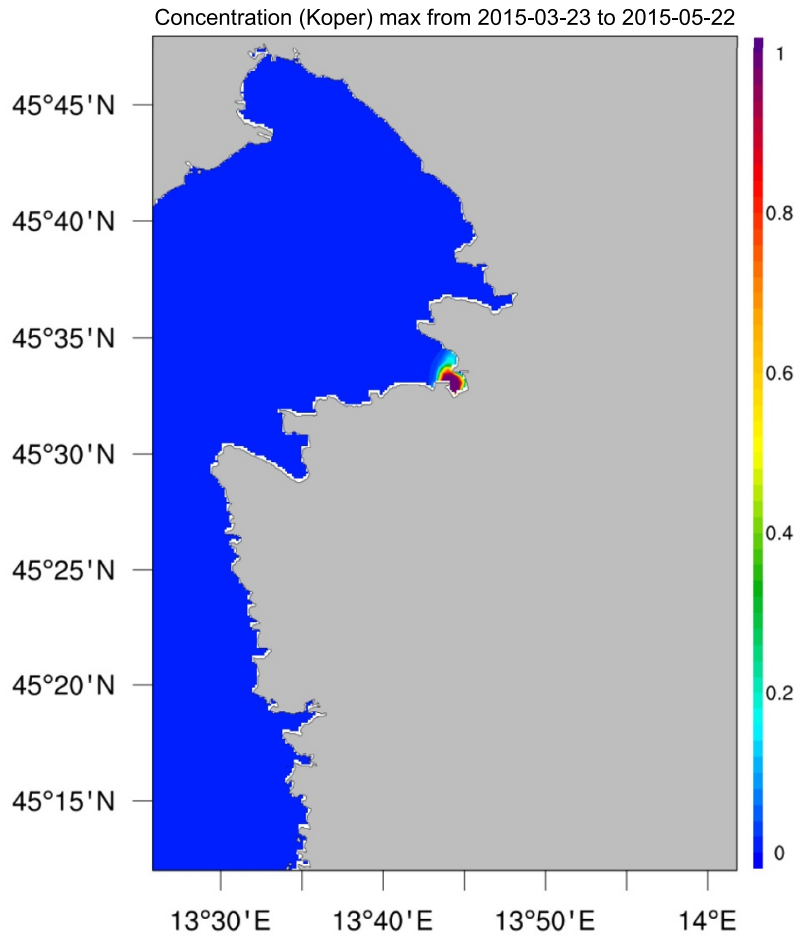

Concentration (Koper) max from 2014-11-18 to 2015-01-17

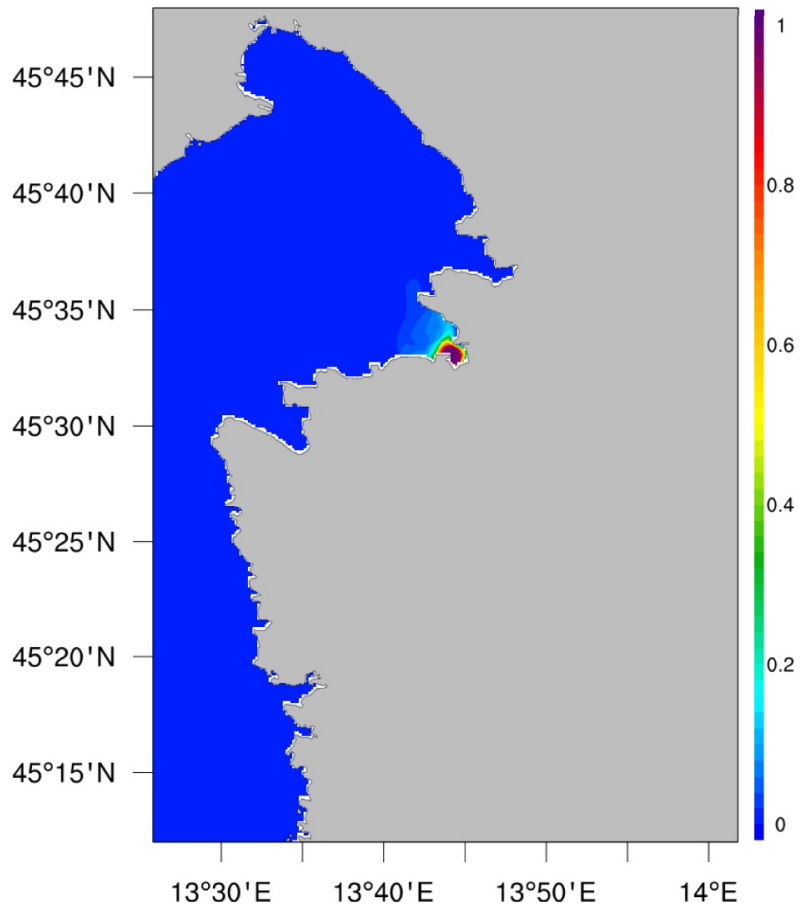

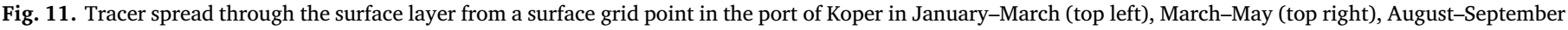
(bottom left), and November-January (bottom right).

together with the much more intense westward spread, is also a possibility; this would result in a potential two-way spread between Italy and Croatia. However, data analysis indicates that in summer HAOP retention is likeliest in most ports, whereas spread would be likely only from Bar and Trieste and possibly from Durrës, Koper, and Venice. HAOP spread from the largest number of ports (Bar, Bari, Koper, Ploče, Pula, Rijeka, Trieste, and Venice) should occur in autumn. From the Italian ports (Bari, Trieste, and Venice), HAOP might spread quite far, since they would be carried south along the western coast by the WAC, be caught up in the SAP gyre, then pushed eastward and later northwards (including HAOP from Bar and Ploče) up towards the central Adriatic. There, they would most probably be redirected back to the western coast by the JP gyre, and then again southwards. HAOP from the port of Koper would probably spread over the northern Adriatic coastal area, whereas the westward spread from Pula and Rijeka towards the Italian coast would be most pronounced in autumn.

In strong wind conditions, particle displacement would be different and faster. The possibility of eastward spread from the port of Rijeka to 

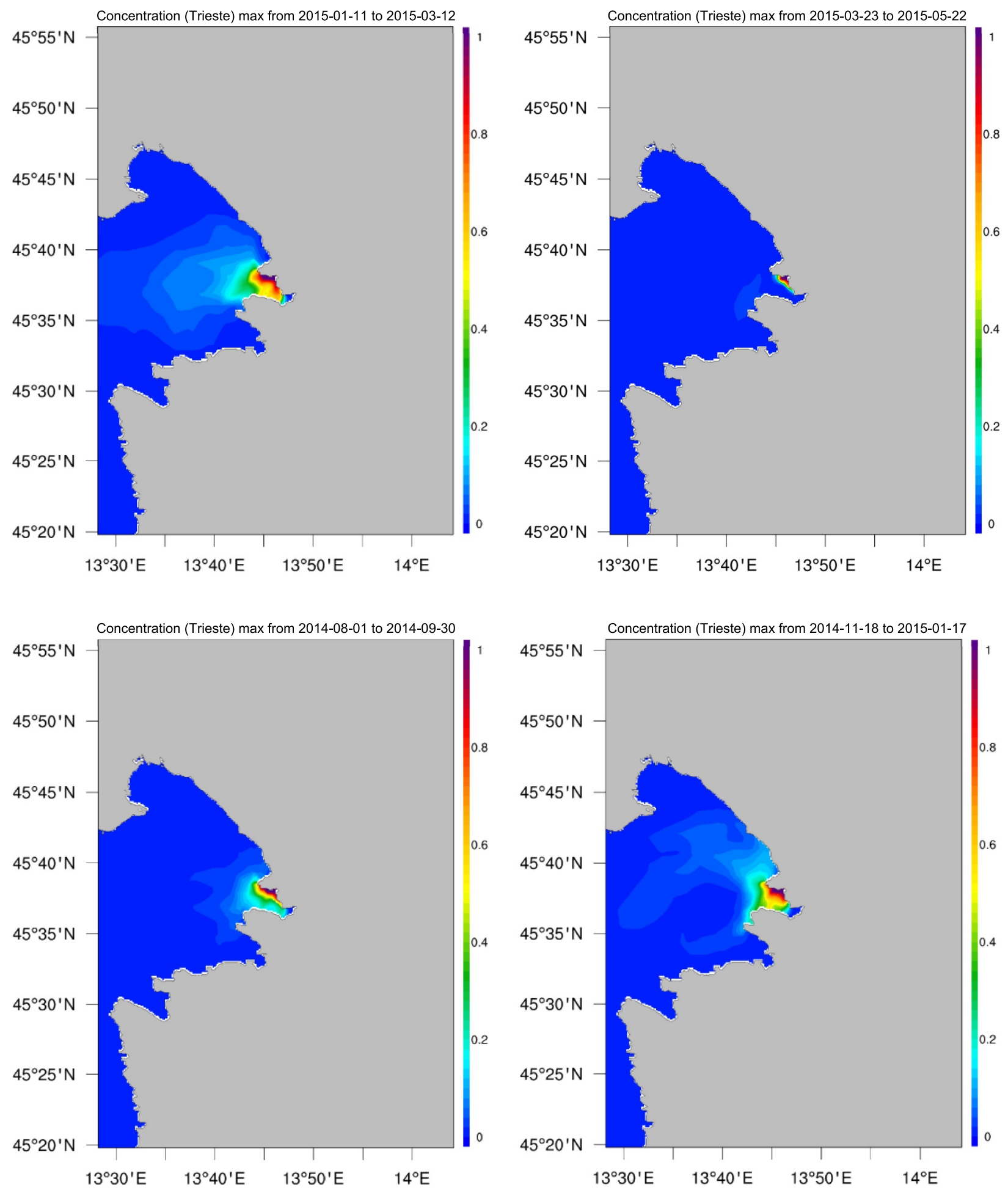

Fig. 12. Tracer spread through the surface layer from a surface grid point in the port of Trieste in January-March (top left), March-May (top right), August-September (bottom left), and November-January (bottom right).

the Italian coast, or even only out of the port into the wider Adriatic circulation during intense Bora episodes, has been suggested by a meteorological model during Bora peaks in September 2002 (Boldrin et al., 2009). Notably, during the most intense Bora events the bottom layers are also affected throughout the Italian coast, with maxima around and south of the Po delta. According to the measurements taken at the KRB entrance, currents induced by strong Bora winds can affect the entire water column, from surface to bottom in all seasons; being outflow currents they can induce massive spread of particles lying at all levels of the water column, even in sediment, towards the northern and/or central Adriatic.

Though simpler, the spread pattern modelled for the bottom layer shows some unexpected features. A similar circulation pattern would be seen in autumn, winter, and spring (weakest in winter). HAOP introduced in any of the northern Adriatic ports (Venice, Trieste, Koper, Pula, and Rijeka) would remain in the area because the anticyclonic 


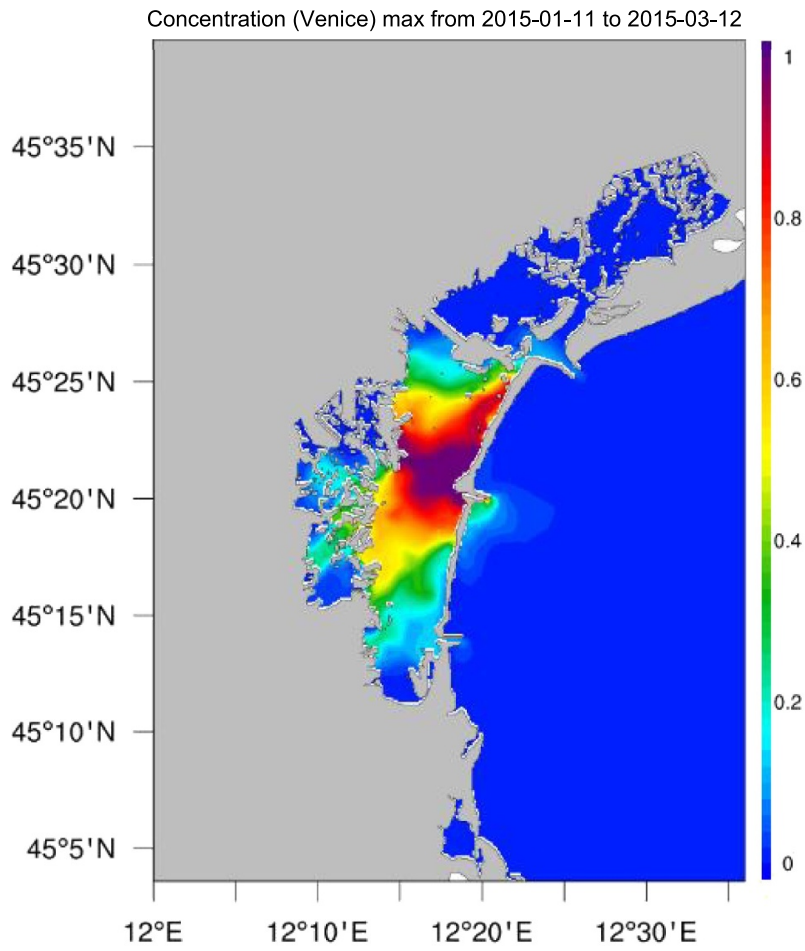

Concentration (Venice) max from 2014-08-01 to 2014-09-30

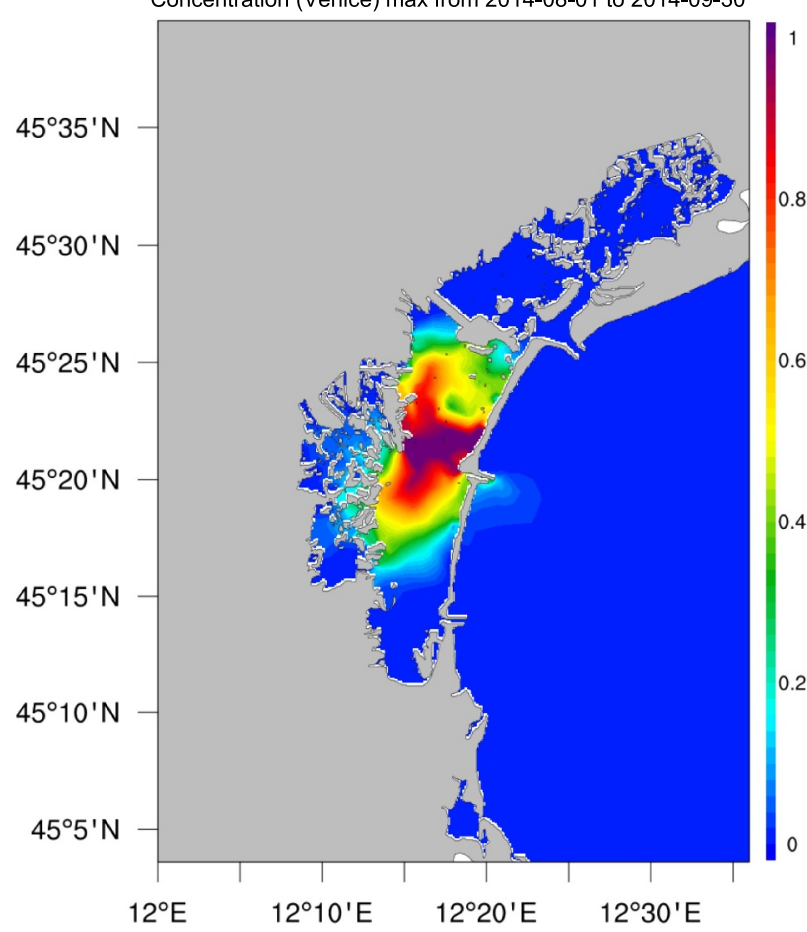

Concentration (Venice) max from 2015-03-23 to 2015-05-22

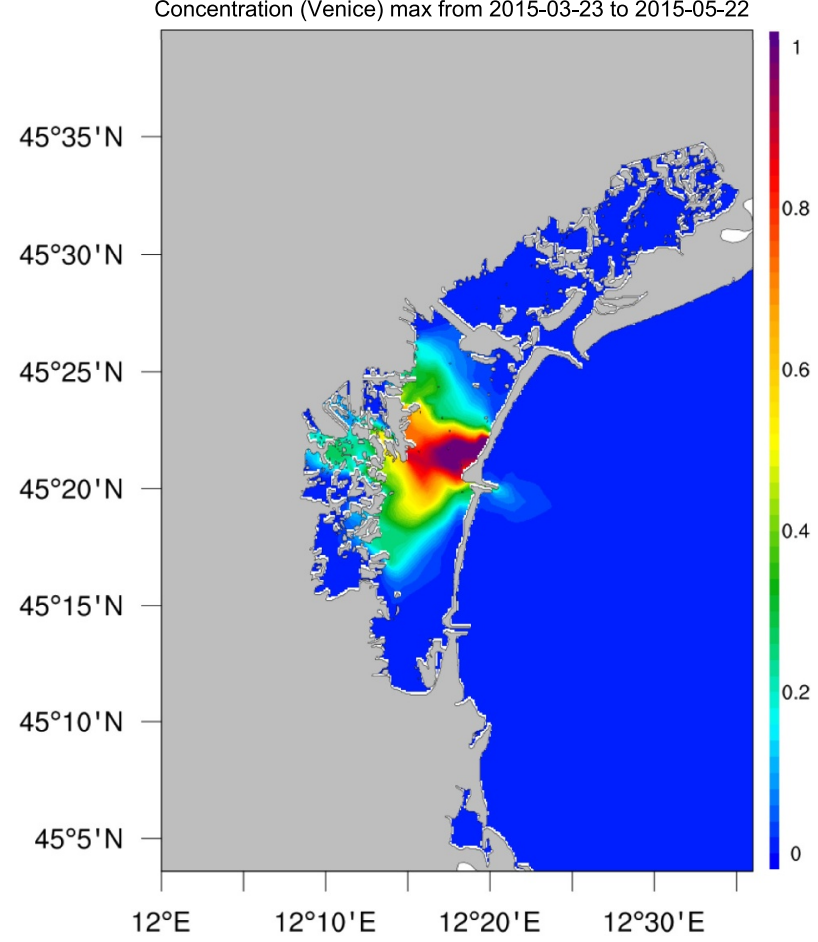

Concentration (Venice) max from 2014-11-18 to 2015-01-17

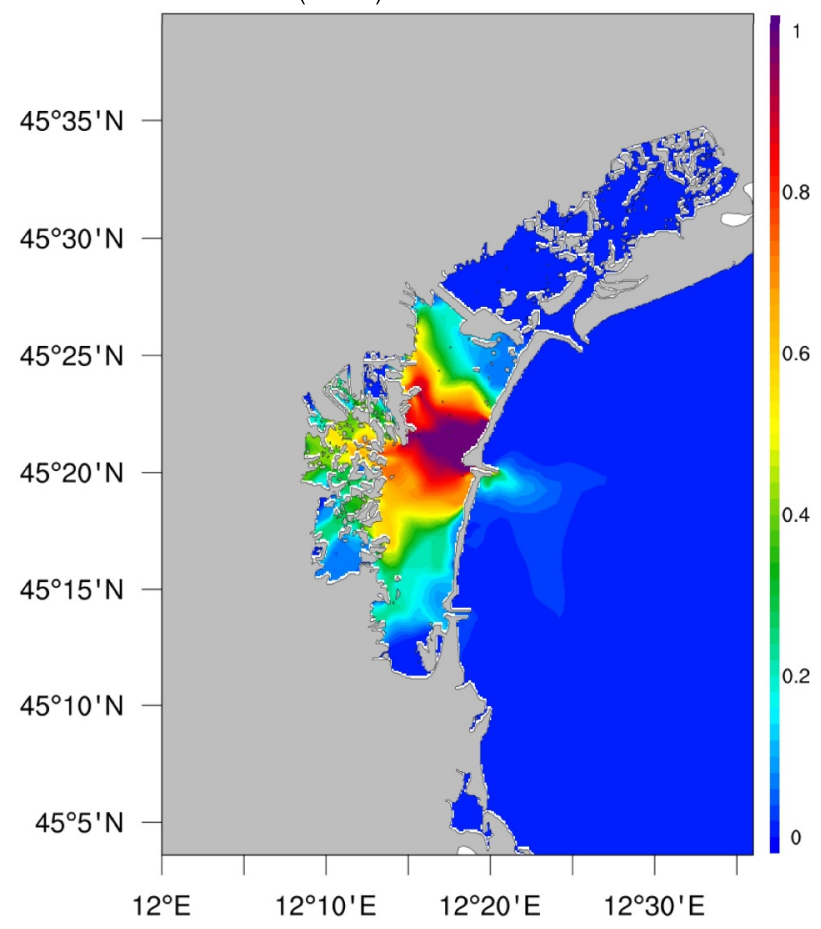

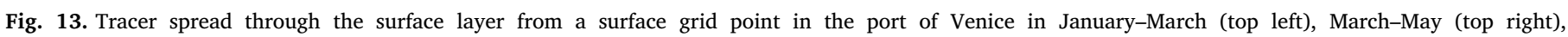
August-September (bottom left), and November-January (bottom right).

pattern would induce spread from KRB and the Istrian coast over to the western coast, then northwards, including to some degree the Gulf of Trieste. Material from the eastern ports (Durrës, Bar, Ploče, Split, and Šibenik) would be carried northwards to the central Adriatic, where it would be redirected westwards to the central Italian coast by the JP cyclonic gyre. In summer, the pattern in the central and southern Adriatic would be expected to remain unchanged. However, the study showed that north of the JP gyre the circulation was northward in the western half of the northern Adriatic, and eastward in the eastern half, suggesting that in summer the Adriatic bottom circulation in the northern and southern areas is divided, and that particles can spread from the western coast to the northern and eastern side of the Adriatic.

It is well documented that resuspension of fine sediments plays a key role in sediment-water interactions and in metal, nutrient, and organic pollutant cycles (Sondergaard, 1990; Horowitz, 1991; Salomons, 1995; Martino et al., 2002; Huettel et al., 2003; Cozar et al., 

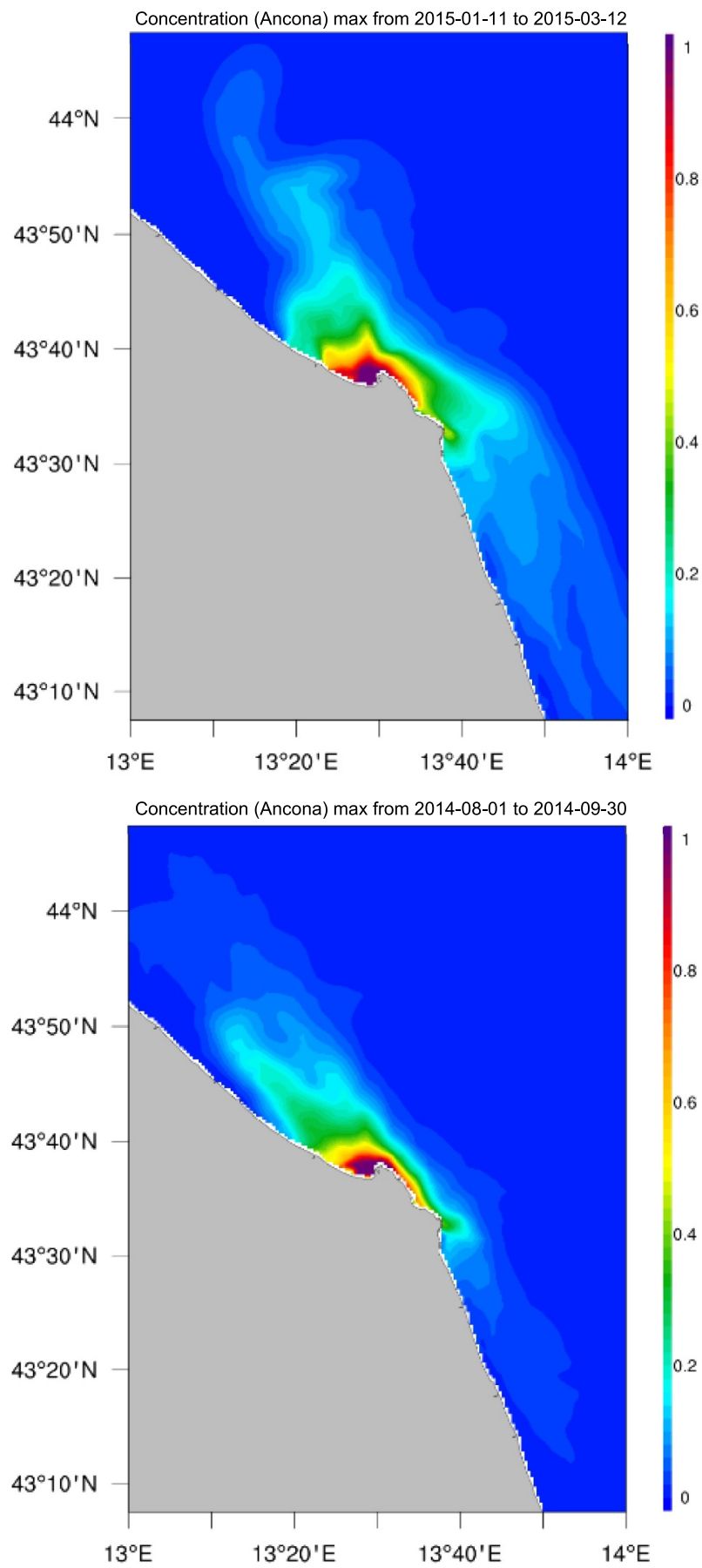
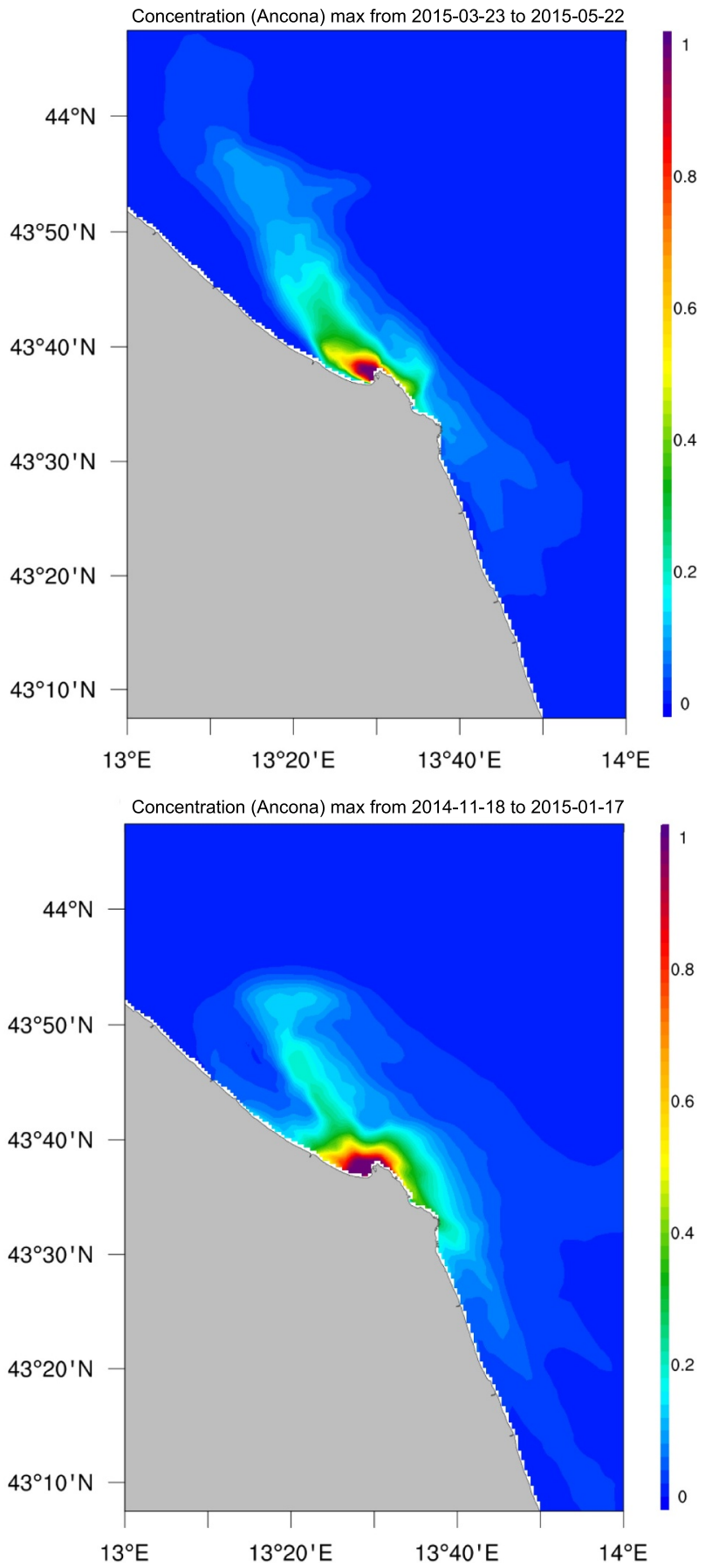

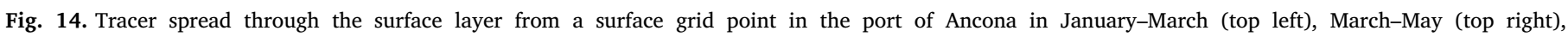
August-September (bottom left), and November-January (bottom right).

2005). At times of high shear stress, fine particles are also transported with the water masses (Hakanson and Jansson, 1983). Besides natural causes, such as strong winds, tidal currents, and bioperturbation (Bengtsson and Hellström, 1992; Graf and Rosenberg, 1997; Linge, 2008), resuspension can be triggered by activities in port areas, such as manoeuvring of large vessels, which can have significant impacts, especially in relatively shallow basins (Mali et al., 2017).

The transport of particles trapped in sediment usually depends on grain size. The Hjulström diagram is generally applied to determine the relationship between grain size and velocity for erosion, transportation, deposition, and settling velocity. For example, in Rijeka Bay sandy sediments prevail along the coast and fine-grained sediments are predominant in the central part (Juračić et al., 1999). According to our interpretation of the Hjulström diagram, the mud $(<0.063 \mathrm{~mm})$ and sand $(0.063-2 \mathrm{~mm})$ particles found in the central and coastal areas of Rijeka Bay would be eroded by bottom currents of around $1 \mathrm{~ms}^{-1}$, similar to those observed after strong wind events at the KRB entrance. Sediment transport across the port entrance warrants further investigation, given the possible adverse consequences of HAOP dispersal, which are most likely to occur in strong current and tide conditions, especially in shallow areas. The present data indicate that the role of HAOP transport from bottom sediments to the open sea may have significant implications which may have been underestimated by previous research. The impact of shipping on bottom sediment erosion in the Gulf of Trieste has already been evaluated (Perkovič et al., 2011), and a strong correlation has been reported between manoeuvring of 

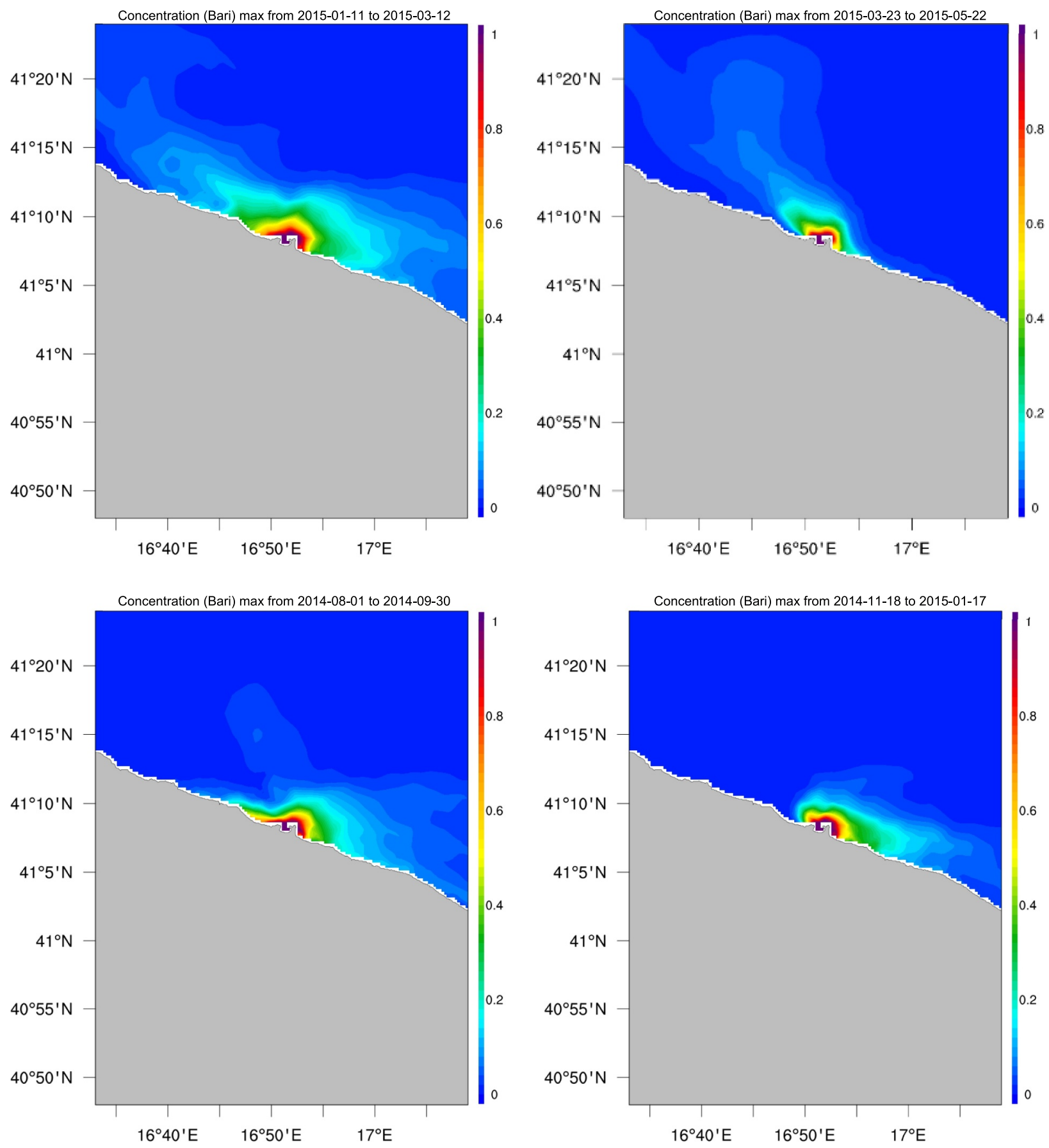

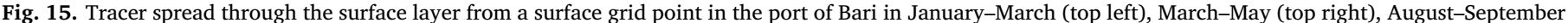
(bottom left), and November-January (bottom right).

large ships and turbidity peaks (Malačič et al., 2010); such peaks were higher than any of those measured in high wind conditions. The influence of shipping on sediment transport and resuspension in the northern Adriatic should thus be addressed in combination with the impact of wind-induced currents and waves (Žagar et al., 2014). These considerations warrant a thorough investigation of water circulation patterns in ports (e.g. Ben Meftah et al., 2011; Mali et al., 2017).

\section{Conclusion}

Our study indicates that the secondary spread of HAOP from ports to adjacent sea areas after their release in ballast water varies between seasons and can occur either through the surface circulation and, after sinking and accumulation of the organisms in port, through the bottom circulation. Factors that seem to favour HAOP spread include the geographic position of the port on the open coast, the lack of breakwaters and other barriers like a narrow opening, a shallow bottom, and winds blowing towards the port opening. Frequent, significant differences in nutrient concentrations and limitations, detected between port and adjacent open sea areas, are likely to affect phytoplankton biomass production; however, further work is required to establish whether and to what extent they contribute to the barrier effect. Notably, port information such as data on currents and diffusion and sedimentation rates are held to be indispensable in understanding HAOP spread from port. Investigation of their surface and bottom spread from 12 Adriatic ports highlighted some differences and seasonal variations. In 

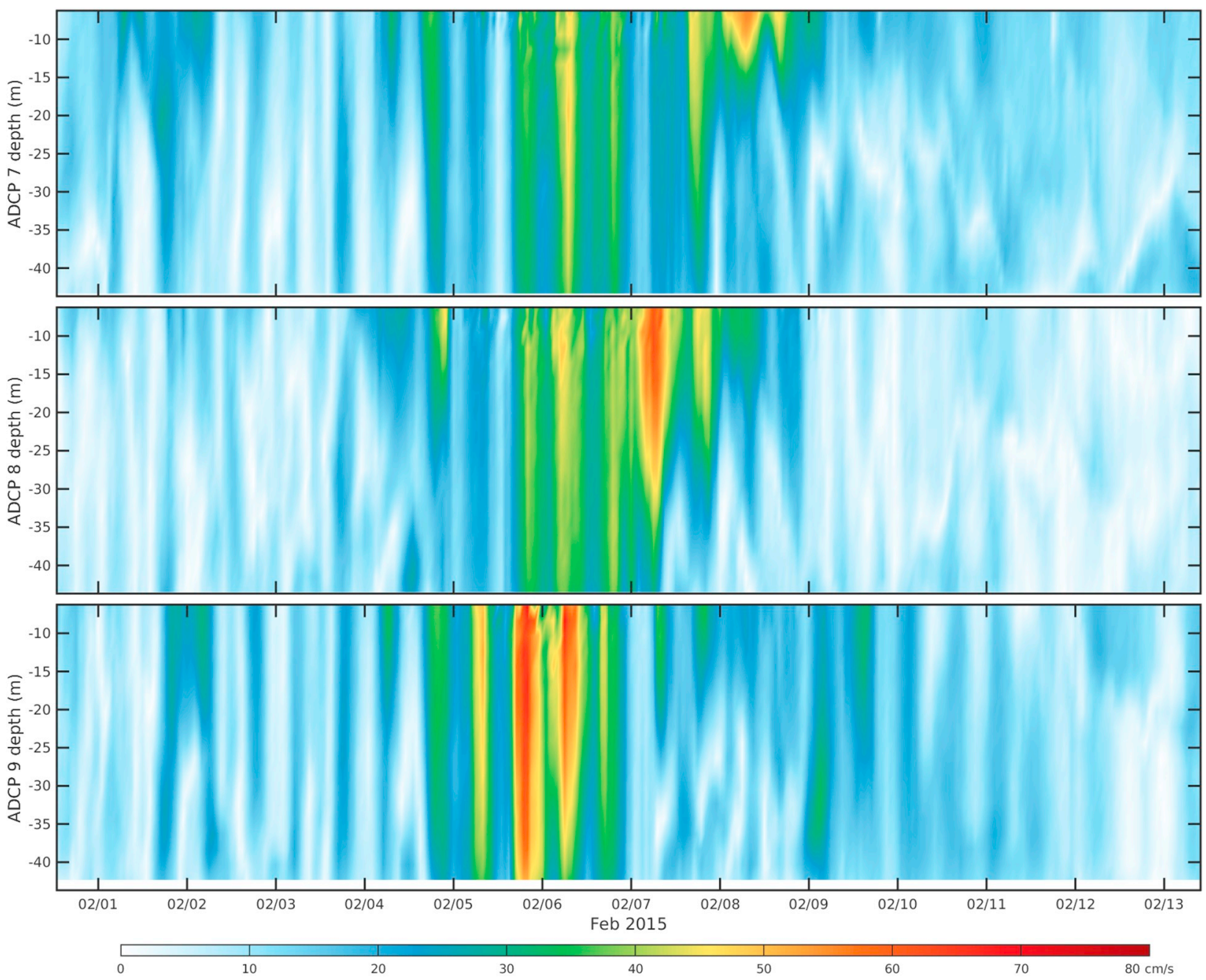

Fig. 16. Current speed $\left(\mathrm{cm} \mathrm{s}^{-1}\right)$ at the three Acoustic Doppler Current Profiler (ADCP) sampling sites during the strong Bora event in February 2015.

particular, transverse spread due to the action of the JP and SAP cyclonic gyres, a westward spread from the KRB entrance over to the Italian coast induced by strong Bora episodes, and the EAC circulation northward along the eastern coast and southward along the western coast - contribute to secondary HAOP spread in the Adriatic. The data presented above indicate that the establishment of regular port monitoring and of an early warning system would provide for effective management of ballast water.

Supplementary data to this article can be found online at https:// doi.org/10.1016/j.marpolbul.2018.10.062.

\section{Acknowledgements}

This publication has been produced with the financial assistance of the IPA Adriatic Cross-Border Cooperation Programme - strategic project Ballast Water Management System for Adriatic Sea Protection (BALMAS). The contents of this publication are the sole responsibility of authors and can under no circumstances be regarded as reflecting the position of the IPA Adriatic Cross-Border Cooperation Programme Authorities. The study has been additionally supported by the Croatian Science Foundation under the Projects EcoRENA (IP-2016-06-4764) and ADAM-ADRIA (IP-2013-11-5928).

We highly appreciate reviewer's valuable and insightful comments and suggestions that greatly improved our manuscript.

\section{References}

Artegiani, A., Bregant, D., Paschini, E., Pinardi, N., Raicich, F., Russo, A., 1997. The Adriatic Sea general circulation. Part I. Air-sea interactions and water mass structure. J. Phys. Oceanogr. 27, 1492-1514. https://doi.org/10.1175/1520-0485(1997) $027<1492:$ TASGCP > 2.0.CO;2.

Ben Meftah, M., Damiani, L., De Serio, F., Mossa, M., Petrillo, A.F., 2011. Analysis of current circulation in the Port of Bari. Geo-eco-marina 17, 5-12. https://doi.org/10. 5281/zenodo.56884.

Bengtsson, L., Hellström, T., 1992. Wind-induced resuspension in a small shallow lake. Hydrobiologia 24, 163-172. https://doi.org/10.1007/BF00028639.

Boldrin, A., Carniel, S., Giani, M., Marini, M., Aubry, F.B., Campanelli, A., Grilli, F., Russo, A., 2009. Effects of bora wind on physical and biogeochemical properties of stratified waters in the northern Adriatic. J. Geophys. Res. Oceans 114, C08S92. https://doi. org/10.1029/2008JC004837.

Bower, C.E., Holm-Hansen, T., 1980a. A simplified hydrazine-reduction method for determining high concentrations of nitrate in recirculated seawater. Aquaculture 21, 281-286. https://doi.org/10.1016/0044-8486(80)90137-4.

Bower, C.E., Holm-Hansen, T., 1980b. Salicylate-hypochlorite method for determining ammonia in seawater. Can. J. Fish. Aquat. Sci. 37, 794-798. https://doi.org/10. 1139/f80-106.

Bran + Luebbe, 2004. Nutrients in Water and Seawater. Bran + Luebbe, Norderstedt, Germany.

Brooks, M.L., 1999. Habitat invasibility and dominance by alien annual plants in the Western Mojave Desert. Biol. Invasions 1, 325-337. https://doi.org/10.1023/ A:1010057726056

Cardeccia, A., Marchini, A., Occhipinti-Ambrogi, A., Galil, B.S., Gollasch, S., Minchin, D., Narscius, A., Olenin, S., Ojaveer, H., 2016. Assessing biological invasions in European seas: biological traits of the most widespread non-indigenous species. Estuar. Coast. Shelf Sci. 201, 17-28. https://doi.org/10.1016/j.ecss.2016.02.014.

Catford, J.A., Vesk, P.A., Richardson, D.M., Pyšek, P., 2012. Quantifying levels of biological invasion: towards the objective classification of invaded and invasible ecosystems. Glob. Chang. Biol. 18, 44-62. https://doi.org/10.1111/j.1365-2486.2011 02549.x. 
Colautti, R.I., Grigorovich, I.A., MacIsaac, H.J., 2006. Propagule pressure: a null model for biological invasions. Biol. Invasions 8, 1023-1037. https://doi.org/10.1007/ s10530-005-3735-y.

Cozar, A., Galvez, J.A., Hull, V., Garcia, C.M., Loiselle, S.A., 2005. Sediment resuspension by wind in a shallow lake of Esteros del Ibera (Argentina): a model based on turbidity. Ecol. Model. 186, 63-76. https://doi.org/10.1016/j.ecolmodel.2005.01.020.

Cozzi, S., Giani, M., 2011. River water and nutrient discharges in the Northern Adriatic Sea: current importance and long term changes. Cont. Shelf Res. 31, 1881-1893. https://doi.org/10.1016/j.csr.2011.08.010.

Cushman-Roisin, B., Gačić, M., Poulain, P., Artegiani, A., 2001. Physical Oceanography of the Adriatic Sea: Past, Present and Future. Kluwer Academic Publishers, Dordrecht, Boston, London. https://doi.org/10.1007/978-94-015-9819-4. 245 pp.

David, M., Gollasch, S., Leppäkoski, E., 2013. Risk assessment for exemptions from ballast water management - the Baltic Sea case study. Mar. Pollut. Bull. 75, 205-217.

Davis, M.A., Grime, J.P., Thompson, K., 2000. Fluctuating resources in plant communities: a general theory of invasibility. J. Ecol. 88, 528-534. https://doi.org/10. 1046/j.1365-2745.2000.00473.x.

Djakovac, T., Degobbis, D., Supić, N., Precali, R., 2012. Marked reduction of eutrophication pressure in the northeastern Adriatic in the period 2000-2009. Estuar. Coast. Shelf Sci. 115, 25-32. https://doi.org/10.1016/j.ecss.2012.03.029.

Djakovac, T., Supić, N., Bernardi Aubry, F., Degobbis, D., Giani, M., 2015. Mechanisms of hypoxia frequency changes in the northern Adriatic Sea during the period 1972-2012. J. Mar. Syst. 141, 179-189. https://doi.org/10.1016/j.jmarsys.2014.08. 001.

EPA Method 445.0, 1997. In vitro determination of chlorophyll a and phephytin a in marine and freshwater Algae by fluorescence. National Exposure Research Laboratory, Office of Research and Development, U.S. Envirom. Protection Ag., Cincinnati, Ohio, pp. 22

Ferrarin, C., Cucco, A., Umgiesser, G., Bellafiore, D., Amos, C.L., 2010. Modelling fluxes of water and sediment between Venice Lagoon and the sea. Cont. Shelf Res. 30, 904-914. https://doi.org/10.1016/j.csr.2009.08.014.

Galil, B.S., 2009. Taking stock: inventory of alien species in the Mediterranean sea. Biol. Invasions 11, 359-372. https://doi.org/10.1007/s10530-008-9253-y.

Galil, B.S., Marchini, A., Occhipinti-Ambrogi, A., Minchin, D., Narščius, A., Ojaveer, H., Olenin, S., 2014. International arrivals: widespread bioinvasions in European seas. Ethol. Ecol. Evol. 26, 152-171. https://doi.org/10.1080/03949370.2014.897651.

GISP, 2008. Global Invasive Species Programme. Marine Biofouling: An Assessment of Risks and Management Initiatives. Compiled by Lynn Jackson on Behalf of the Global Invasive Species Programme and the UNEP Regional Seas Programme. (68 pp.).

Gollasch, S., Minchin, D., David, M., 2015. The transfer of harmful aquatic organisms and pathogens with ballast water and their impacts. In: David, M., Gollasch, S. (Eds.), Global Maritime Transport and Ballast Water Management. Invading Nature-Springer Series in Invasion Ecology 8. pp. 35-58. https://doi.org/10.1007/978-94-017-936743.

Graf, G., Rosenberg, R., 1997. Bioresuspension and biodeposition: a review. J. Mar. Syst. 11, 269-278. https://doi.org/10.1016/S0924-7963(96)00126-1.

Grasshoff, K., 1976. Methods of Seawater Analysis. Verlag Chemie, Weinheim, pp. 307.

Grasshoff, K., Kremlingl, K., Ehrhardt, M. (Eds.), 1999. Methods of Seawater Analysis, 3rd completely revised and extended edition. Wiley-VCH, Weinheim (600 pp.).

Hakanson, L., Jansson, M., 1983. Principles of Lake Sedimentology. Springer-Verlag, New York, pp. 148.

Hansen, H.P., Koroleff, F., 1999. Determination of nutrients. In: Grasshoff, K., Kremling, K., Ehrhardt, M. (Eds.), Methods of Seawater Analysis. Wiley-VCH Verlag GmbH, Weinheim, Germany, pp. 203-205. https://doi.org/10.1002/9783527613984.ch10.

Herbold, B., Moyle, P.B., 1986. Introduced species and vacant niches. Am. Nat. 128, $751-760$.

Holm-Hansen, O., Lorenzen, C.J., Holmes, R.W., Strickland, J.D.H., 1965. Fluorometric determination of chlorophyll. J. Cons. Int. Explor. Mer 30, 3-15. https://doi.org/10 1093/icesjms/30.1.3.

Hopkins, T.S., Artegiani, A., Bignami, F., Russo, A., 1999. Water-mass modification in the Northern Adriatic: a preliminary assessment from the ELNA data set. In: Ecosystem Research Report 32, The Adriatic Sea, pp. 3-29.

Horowitz, A.J., 1991. A Primer on Sediment-Trace Element Chemistry, 2nd ed. Lewis Publishers, Inc., Chelsea, MI (136 pp.).

Huettel, M., Roy, H., Precht, E., Ehrenhauss, S., 2003. Hydrodynamical impact on biogeochemical processes in aquatic sediments. Hydrobiology 494, 231-236. https:// doi.org/10.1023/A:1025426601773.

IMO, 2004. International Convention for the Control and Management of Ships' Ballast Water and Sediments. International Maritime Organization, London, UK 13 February 2004. (36 pp.)

IMO, 2005. Guidelines for Ballast Water Management and Development of Ballast Water Management Plan (G4). Marine Environment Protection Committee, Resolution MEPC. 127(53) International Maritime Organization, London, UK 22 July 2005 (16 pp.).

Ivančić, I., Degobbis, D., 1984. An optimal manual procedure for ammonia analysis in natural waters by the indophenol blue method. Water Res. 18, 1143-1147. https:// doi.org/10.1016/0043-1354(84)90230-6.

Janeković, I., Dutour Sikirić, M., Tomažić, I., Kuzmić, M., 2010. Hindcasting the Adriatic Sea surface temperature and salinity: a recent modeling experience. Geofizika 27, 85-100.

Janeković, I., Mihanović, H., Vilibić, I., Tudor, M., 2014. Extreme cooling and dense water formation estimates in open and coastal regions of the Adriatic Sea during the winter of 2012. J. Geophys. Res. Oceans 119, 3200-3218. https://doi.org/10.1002/ 2014JC009865.

Jeffrey, S.W., Mantoura, R.F.C., Wright, S.W., 1997. Phytoplankton Pigments in Oceanography. UNESCO, Paris (661 pp.).
Jeffries, M.A., Lee, C.M., 2007. A climatology of the northern Adriatic Sea's response to bora and river forcing. J. Geophys. Res. 118, C03S02. https://doi.org/10.1029/ 2006JC003664.

Juračić, M., Benac, Č., Crmarić, R., 1999. Seabed and Surface Sediment Map of the Kvarner Region, Adriatic Sea, Croatia. Geologia Croat. 52, 131-140.

Katsanevakis, S., Zenetos, A., Belchior, C., Cardoso, A.C., 2013. Invading European seas: assessing pathways of introduction of marine aliens. Ocean Coast. Manag. 76, 64-74. https://doi.org/10.1016/j.ocecoaman.2013.02.024.

Kraus, R., Supić, N., 2011. Impact of circulation on high phytoplankton blooms and fish catch in the northern Adriatic (1990-2004). Estuar. Coast. Shelf Sci. 91, 198-210. https://doi.org/10.1016/j.ecss.2010.10.021.

Kraus, R., Ninčević-Gladan, Ž., Auriemma, R., Bastianini, M., Bolognini, L., Cabrini, M., Cara, M., Čalić, M., Campanelli, A., Cvitković, I., Despalatović, M., Drakulović, D., Flander-Putrle, V., Grati, F., Grego, M., Grilli, F., Jaklin, A., Janeković, I., Kolitari, J., Lipej, L., Magaletti, E., Marini, M., Mavrič, B., Mikus, J., Mozetič, P., Orlando-Bonaca, M., Petović, S., Precali, R., Supić, N., Trabucco, B., Travizi, A., Žuljević, A., 2018. Strategy of Port Baseline Survey (PBS) in the Adriatic Sea. (This issue).

Linge, K.L., 2008. Methods for investigating trace element binding in sediments. Crit. Rev. Environ. Sci. Technol. 38, 165-196. https://doi.org/10.1080/10643380601174780.

Lipizer, M., Partescano, E., Rabitti, A., Giorgetti, A., Crise, A., 2014. Qualified temperature, salinity and dissolved oxygen climatologies in a changing Adriatic Sea. Ocean Sci. 10, 771-797. https://doi.org/10.5194/os-10-771-2014.

Lorenzen, C.J., Jeffrey, S., 1980. Determination of chlorophyll in seawater. SCORUNESCO. UNESCO Tech. Pap. Mar. Sci. 35, 1-20.

Lotze, H.K., Lenihan, H.S., Bourque, B.J., Bradbury, R.H., Cooke, R.G., Kay, M.C., Kidwell, S.M., Kirby, M.X., Peterson, C.H., Jackson, J.B.C., 2006. Depletion, degradation, and recovery potential of estuaries and coastal seas. Science 312, 1806-1809. https://doi. org/10.1126/science.1128035.

Lyons, D.M., Supić, N., Smodlaka, N., 2007. Geostrophic circulation patterns in the northeastern Adriatic Sea and the effects of air-sea coupling: May-September 2003. J. Geophys. Res. 112, C03S08. https://doi.org/10.1029/2005JC003100.

Malačič, V., Petelin, B., Žagar, D., Bajt, O., Ramšak, A., Vodopivec, M., Čermelj, B., 2010. Circulation and environmental state in the Koper Bay and Port Koper (in Slovenian). 35 National Institute of Biology, Marine Biology Station, Report 120.

Mali, M., De Serio, F., Dell'Anna, M.M., Mastrorilli, P., Damiani, L., Mossa, M., 2017. Enhancing the performance of hazard indexes in assessing hot spots of harbour areas by considering hydrodynamic parameters. Ecol. Indic. 73, 38-45. https://doi.org/10. 1016/j.ecolind.2016.09.028.

Marić, D., Kraus, R., Godrijan, J., Supić, N., Dakovac, T., Precali, R., 2012. Phytoplankton response to climatic and anthropogenic influences in the north-eastern Adriatic during the last four decades. Estuar. Coast. Shelf Sci. 115, 98-112. https://doi.org/ 10.1016/j.ecss.2012.02.003.

Marini, M., Jones, B.H., Campanelli, A., Grilli, F., Lee, C.M., 2008. Seasonal variability and Po River plume influence on biochemical properties along western Adriatic coast. J. Geophys. Res. 113, C05S90. https://doi.org/10.1029/2007JC004370.

Martino, M., Turner, A., Nimmo, M., Millward, G.E., 2002. Resuspension, reactivity and cycling of trace metals in the Mersey Estuary, UK. Mar. Chem. 77, 171-186. https:// doi.org/10.1016/S0304-4203(01)00086-X.

Minton, M.S., Verling, E., Whitman Miller, A., Ruiz, G.M., 2005. Reducing propagule supply and coastal invasions via ships: effects of emerging strategies. Front. Ecol. Environ. 3, 304-308. https://doi.org/10.1890/1540-9295(2005)003[0304:RPSACI] 2.0.CO;2.

Molnar, J.L., Gamboa, R.L., Revenga, C., Spalding, M.D., 2008. Assessing the global threat of invasive species to marine biodiversity. Front. Ecol. Environ. 6, 485-492. https:// doi.org/10.1890/070064.

Mozetič, P., Solidoro, C., Cossarini, G., Socal, G., Precali, R., Francé, J., Bianchi, F., De Vittor, C., Smodlaka, N., Fonda Umani, S., 2010. Recent trends towards oligotrophication of the Northern Adriatic: evidence from chlorophyll a time series. Estuar. Coasts 33, 362-375. https://doi.org/10.1007/s12237-009-9191-7.

Nehring, S., 2002. Biological invasions into German waters: an evaluation of the im portance of different humanmediated vectors for nonindigenous macrozoobenthic species. In: Leppäkoski, E., Gollasch, S., Olenin, S. (Eds.), Invasive Aquatic Species of Europe. Distribution, Impacts and Management. Kluwer Academic Publishers, Dordrecht, Boston, London, pp. 374-384.

Nilsson, N.A., 1984. The niche concept and the introduction of exotics. EIFAC Tech. Pap. 42, 496-509.

Ninčević Gladan, Ž., Magaletti, E., Scarpato, A., Azzurro, E., Bacci, T., Berto, D., Dulčić, J., Gennaro, P., Marusso, V., Penna, M., Rampazzo, F., Rende, F.S., Romanelli, G., Vidjak, O., Trabucco, B., Žuljević, A., 2014. BALMAS Port Baseline Survey Protocol. Protocol. BALMAS Project. Work Package 5.1. (28 pp.).

Paavola, M., Olenin, S., Leppäkoski, E., 2005. Are invasive species most successful in habitats of low native species richness across European brackish water seas? Estuar. Coast. Shelf Sci. 64, 738-750. https://doi.org/10.1016/j.ecss.2005.03.021.

Parsons, T.R., Maita, Y., Lalli, C.M., 1984. A Manual of Chemical and Biological Methods for Seawater Analysis. Pergamon Press, Oxford, New York, Toronto, Sydney and Frankfurt (173 pp.).

Perkovič, M., Batista, M., Jankowski, S., 2011. Vpliv predvidenega povečanja ladijskega prometa na varnost in okolje Tržaškega zaliva (in Slovenian). Faculty of maritime studies and transport, Report.

Ruiz, G.M., Hewitt, C.L., 2002. Toward understanding patters of coastal marine invasions: a prospectus. In: Leppäkoski, E., Gollasch, S., Olenin, S. (Eds.), Invasive Aquatic Species of Europe. Distribution, Impacts and Management. Kluwer Academic Publishers, Dordrecht, Boston, London, pp. 529-547.

Ruiz, G.M., Fofonoff, P., Hines, A.H., Grosholz, E.D., 1999. Non-indigenous species as stressors in estuarine and marine communities: assessing invasion impacts and in teractions. Limnol. Oceanogr. 44, 950-972. https://doi.org/10.4319/lo.1999.44.3 
part 2.0950 .

Ruiz, G.M., Fofonoff, P.W., Carlton, J.T., Wonham, M.J., Hines, A.H., 2000. Invasion of coastal marine communities in North America: apparent patterns, processes, and biases. Annu. Rev. Ecol. Syst. 31, 481-531. https://doi.org/10.1146/annurev. ecolsys.31.1.481.

Salomons, W., 1995. Environmental impact of metals derived from mining activities: processes, predictions, prevention. J. Geochem. Explor. 52, 5-23. https://doi.org/10. 1016/0375-6742(94)00039-E.

Sara, G., Porporato, E.M.D., Cristina Mangano, M., Mieszkowska, N., 2018. Multiple stressors facilitate the spread of a non-indigenous bivalve in the Mediterranean Sea. J. Biogeogr. 45, 1090-1103. https://doi.org/10.1111/jbi.13184.

Simberloff, D., Von Holle, B., 1999. Positive interactions of nonindigenous species: invasional meltdown? Biol. Invasions 1, 21-32. https://doi.org/10.1023/ A:1010086329619.

Solidoro, C., Bastianini, M., Bandelj, V., Codermatz, R., Cossarini, G., Melaku Canu, D. Ravagnan, E., Salon, S., Trevisani, S., 2009. Current state, scales of variability, and trends of biogeochemical properties in the northern Adriatic Sea. J. Geophys. Res. Oceans 114, C07S91. https://doi.org/10.1029/2008JC004838.

Sondergaard, M., 1990. Pore water dynamics in the sediment of a shallow and hypertrophic lake. Hydrobiologia 192, 247-258. https://doi.org/10.1007/BF00006019.

Specchiulli, A., Scirocco, T., D'Adamo, R., Cilenti, L., Fabbrocini, A., Cassin, D., Penna, P., Renzi, M., Bastianoni, S., 2016. Benthic vegetation, chlorophylla and physical-chemical variables in a protected zone of a Mediterranean coastal lagoon (Lesina, Italy). J. Coast. Conserv. 20, 363-374. https://doi.org/10.1007/s11852-016-0449-5.

Strickland, J.D.H., Parsons, T.R., 1968. A Practical Handbook of Seawater Analysis. Bulletin of Fisheries Research Board of Canada 167 (293 pp.).

Strickland, J.D.H., Parsons, T.R., 1972. A Practical Handbook of Seawater Analysis. Bulletin of Fisheries Research Board of Canada 167 (310 pp.).

Supić, N., Kraus, R., Kuzmić, M., Paschini, E., Precali, R., Russo, A., Vilibić, I., 2012. Predictability of northern Adriatic winter conditions. J. Mar. Syst. 90, 42-57. https:// doi.org/10.1016/j.jmarsys.2011.08.008.
Tsiamis, K., Zenetos, A., Deriu, I., Gervasini, E., Cardoso, A.C., 2018. The native distribution range of the European marine non-indigenous species. Aquat. Invasions 13, 187-198. https://doi.org/10.3391/ai.2018.13.2.01.

Van der Velde, G., Nagelkerken, I., Rajagopal, S., de Vaate, A.B., 2002. Invasions by alien species in inland freshwater bodies in western Europe: the Rhine delta. In: Leppäkoski, E., Gollasch, S., Olenin, S. (Eds.), Invasive Aquatic Species of Europe. Distribution, Impacts and Management. Kluwer Academic Publishers, Dordrecht, Boston, London, pp. 360-372.

Vilibić, I., Supić, N., 2005. Dense water generation on a shelf: the case of the Adriatic Sea. Ocean Dyn. 55, 403-415. https://doi.org/10.1007/s10236-005-0030-5.

Vitousek, P.M., D'Antonio, C.M., Loope, L.L., Rejmanek, M., Westbtooks, R., 1997 Introduced species: a significant component of human-caused global change. N. Z. J. Ecol. 21, 1-16.

Williamson, M., Fitter, A., 1996. The varying success of invaders. Ecology 77, 1661-1666. https://doi.org/10.2307/2265769.

Winkler, L.W., 1888. Die Bestimmung des in Wasser gelösten Sauerstoffen. Ber. Dtsch Chem. Ges. 21, 2843-2855. https://doi.org/10.1002/cber.188802102122.

Zaiko, A., Olenin, S., Daunys, D., Nalepa, T., 2007. Vulnerability of benthic habitats to the aquatic invasive species. Biol. Invasions 9, 703-714. https://doi.org/10.1007/ s10530-006-9070-0.

Zaiko, A., Lehtiniemi, M., Naršcius, A., 2011. Assessment of bioinvasion impacts on a regional scale: a comparative approach. Biol. Invasions 13, 1739-1765. https://doi. org/10.1007/s10530-010-9928-z.

Zavatarelli, M., Raicich, F., Artegiani, A., Bregant, D., Russo, A., 1998. Climatological biogeochemical characteristics of the Adriatic Sea. J. Mar. Syst. 18, 227-263. https:// doi.org/10.1016/S0924-7963(98)00014-1.

Zore-Armanda, M., 1963. Les masses d'eau de la mer Adriatique. Acta Adriat. 10, 5-88.

Žagar, D., Ramšak, V., Jeromel, M., Perkovič, M., Ličer, M., Malačič, V., 2014. Modelling sediment resuspension caused by navigation, waves and currents (Gulf of Trieste, northern Adriatic). Proceedings of the 3nd European IAHR Congress, Porto. 